UNIVERSIDADE DE SÃO PAULO

FACULDADE DE ECONOMIA, ADMINISTRAÇÃO E CONTABILIDADE DEPARTAMENTO DE CONTABLIDADE E ATUÁRIA

UMA ANÁLISE DOS EFEITOS INFLACIONÁRIOS SOBRE DEMONSTRAÇÕES CONTÁBEIS DE EMPRESAS BRASILEIRAS TRADUZIDAS PARA APRESENTAÇÃO NO EXTERIOR

\author{
AGRICIONEIDE FEITOSA
}

São Paulo

2002 
Reitor da Universidade de São Paulo

Prof. Dr. Adolpho José Melfi

Diretora da Faculdade de Economia, Administração e Contabilidade

Profa. Dra. Maria Tereza Leme Fleury

Chefe do Departamento de Contabilidade e Atuaria

Prof. Dr. Reinaldo Guerreiro 
UNIVERSIDADE DE SÃO PAULO

FACULDADE DE ECONOMIA, ADMINISTRAÇÃO E CONTABILIDADE DEPARTAMENTO DE CONTABLIDADE E ATUÁRIA

\section{UMA ANÁLISE DOS EFEITOS INFLACIONÁRIOS SOBRE DEMONSTRAÇÕES CONTÁBEIS DE EMPRESAS BRASILEIRAS TRADUZIDAS PARA APRESENTAÇÃO NO EXTERIOR}

AGRICIONEIDE FEITOSA

ORIENTADOR: PROF. DR. ARIOVALDO DOS SANTOS

Dissertação apresentada à Faculdade de Economia, Administração e Contabilidade da Universidade de São Paulo, para a obtenção do título de Mestre em Controladoria e Contabilidade.

São Paulo 


\section{FICHA CATALOGRÁFICA}

Feitosa, Agricioneide

Uma análise dos efeitos inflacionários sobre demonstrações contábeis de empresas brasileiras traduzidas para apresentação no exterior / Agricioneide Feitosa. -- São Paulo :

FEA/USP, 2002.

$151 \mathrm{p}$.

Dissertação - Mestrado

Bibliografia.

1. Correção monetária 2. Inflação 3. Balanço I. Faculdade de Economia, Administração e Contabilidade da USP II. Título.

$$
\text { CDD - } 332.413
$$


DEDICATÓRIA

À minha mãe Neide, por seu carinho e dedicação em todos os momentos. 


\section{AGRADECIMENTOS}

A Deus, fonte de toda sabedoria e justiça.

Ao Prof. Dr. Ariovaldo dos Santos, pelos ensinamentos e sua dedicação na orientação desta dissertaão

Ao Prof. Dr. Geraldo Barbieri e ao Prof. Dr. Lázaro Plácido Lisboa, pelas valiosas contribuições dadas ao trabalho quando do exame de qualificação em 09.10.2002.

Aos Professores do Curso de Mestrado em Controladoria e Contabilidade pelos ensinamentos e oportunidade de convivência.

A Soraidy, Socorro e Moisés, pelo incentivo recebido durante a elaboração deste trabalho.

A todos os colegas de curso, pela convivência saudável e pela solidariedade revelada por todos.

A Maria Lúcia (Malu), pelo apoio prestado, carinho, dedicação e amizade durante a realização desse curso.

Enfim, a todos os que, de uma forma direta ou indireta concorreram para a produção desta pesquisa. 


\section{SUMÁRIO}

INTRODUÇÃO

1. Tradução de demonstrações contábeis para moeda estrangeira __ 7

1.1 Métodos de tradução para moeda estrangeira____ 9

1.1.1 Método temporal

1.1.2 Método monetário / não monetário __ 10

1.1.3 Método corrente / não corrente __ 10

1.1.4 Método da taxa corrente____ 11

1.2 Pronunciamentos do FASB _ 11

1.3 Os Métodos de tradução de demonstrações contábeis para moeda estrangeira utilizados no Brasil __ 22

2. Normas e práticas contábeis do Brasil e dos EUA__ 27

2.1 Órgãos emissores de normas contábeis no Brasil___ 28

2.1.1 Conselho Federal de Contabilidade - CFC _ 28

2.1.2 Instituto dos Auditores Independentes do Brasil - IBRACON__ 28

2.1.3 Comissão de Valores Mobiliários - CVM __ 29

2.1.4 Banco Central do Brasil - BACEN __ 29

2.2 Órgãos emissores de normas contábeis nos Estados Unidos _ 30

2.2.1 American Institute of Certified Public Accountants - AICPA _ 30

2.2.2 Financial Accounting Standards Board - FASB _ 31

2.2.3 Governmental Accounting Standards Board - GASB ___ 31

2.2.4 Securities and Exchange Commission - SEC ___ 31

2.3 Comparação das normas e práticas contábeis___ 32

2.3.1 Conceitos contábeis básicos __ 34

2.3.2 Demonstrações contábeis — 34

2.3.3 Mudança de critérios contábeis __ 36

2.3.4 Ajustes de exercícios anteriores__ 37

2.3.5 Itens Extraordinários__ 38

2.3.6 Eventos subseqüentes__ 39

2.3.7 Contingências__ 41

2.3.8 Clientes, Fornecedores e Financiamentos___ 41

2.3.9 Avaliação de estoques __ 43

2.3.10 Investimentos em outras empresas __ 44

2.3.11 Depreciação __ 47

2.3.12 Reavaliação — 47

2.3.13 Ativo diferido 48

2.3.14 Imposto de renda diferido___ 49

2.3.15 Plano de benefícios pós-emprego _ 50

2.3.16 Leasing__ 52 
3 Histórico da Inflação no Brasil__ 55

4. Análise dos dados _ 71

4.1 Aracruz Celulose S.A. 73

4.2 Companhia Siderúrgica Nacional - CSN _ 86

4.3 COPENE - Petroquímica do Nordeste S.A. _ 95

4.4 Companhia Paranaense de Energia - COPEL___ 119

4.5 Embratel Participações S.A. _ 133

CONCLUSÕES _ 141

BIBLIOGRAFIA__ 146 


\section{LISTA DE TABELAS}

Tabela 1 - ARACRUZ - Balanço Patrimonial Consolidado em 31 de Dezembro de 1996.

Tabela 2 - ARACRUZ - Demonstração do Resultado para o Exercício findo em 31 de Dezembro de 1996.

Tabela 3 - ARACRUZ - Conciliação do Lucro Líquido e do Patrimônio Líquido em 1996.

Tabela 4 - ARACRUZ - Balanço Patrimonial Consolidado em US GAAP em 31 de Dezembro de 1996....................................

Tabela 5 - ARACRUZ - Balanço Patrimonial Consolidado em 31 de Dezembro de 1997.

Tabela 6 - ARACRUZ. - Demonstração do Resultado para o Exercício findo em 31 de Dezembro de 1997.

Tabela 7 - ARACRUZ - Conciliação do Lucro Líquido e do Patrimônio Líquido em 1997.

Tabela 8 - ARACRUZ - Balanço Patrimonial Consolidado em US GAAP em 31 de Dezembro de 1997.

Tabela 9- CSN - Balanço Patrimonial Consolidado em 31 de Dezembro de 1996.

Tabela 10 - CSN - Demonstração do Resultado para Exercício findo 31 de Dezembro de 1996

Tabela 11 - CSN - Conciliação do Lucro Líquido e do Patrimônio Líquido em 1996.

Tabela 12 - CSN - Demonstração do Resultado em US GAAP para Exercício findo 31 de Dezembro de 1996.

Tabela 13 - COPENE - Balanço Patrimonial Consolidado em 31 de Dezembro de 1997.

Tabela 14 - COPENE.- Demonstração do Resultado para o Exercício findo em 31 de Dezembro de 1997.

Tabela 15 - COPENE - Conciliação do Lucro Líquido e do Patrimônio Líquido em 1997. 
Tabela 16 - COPENE - Balanço Patrimonial Consolidado em US GAAP em 31 de Dezembro de 1997.

Tabela 17 - COPENE - Balanço Patrimonial Consolidado em 31 de Dezembro de 1998.

Tabela 18 - COPENE - Demonstração do Resultado para o Exercício findo em 31 de Dezembro de 1998.

Tabela 19 - COPENE - Conciliação do Lucro Líquido e do Patrimônio Líquido em 1998.

Tabela 20 - COPENE - Balanço Patrimonial Consolidado em US GAAP em 31 de Dezembro de 1998.

Tabela 21 - COPENE - Balanço Patrimonial Consolidado em 31 de Dezembro de 1999.

Tabela 22 - COPENE - Demonstração do Resultado para o Exercício findo em 31 de Dezembro de 1999.

Tabela 23 - COPENE - Conciliação do Lucro Líquido e do Patrimônio Líquido em 1999.

Tabela 24 - COPENE - Balanço Patrimonial Consolidado em US GAAP em 31 de Dezembro de 1999.

Tabela 25 - COPEL - Balanço Patrimonial Consolidado em 31 de Dezembro de 1997.

Tabela 26 - COPEL - Demonstração do Resultado para o Exercício findo em 31 de Dezembro de 1997.

Tabela 27 - COPEL - Balanço Patrimonial Consolidado em 31 de Dezembro de 1998.

Tabela 28 - COPEL - Demonstração do Resultado para o Exercício findo em 31 de Dezembro de 1998.

Tabela 29 - COPEL - Balanço Patrimonial Consolidado em 31 de Dezembro de 1999.

Tabela 30 - COPEL - Demonstração do Resultado para o Exercício findo em 31 de Dezembro de 1999.

Tabela 31 - COPEL - Reconciliação do Patrimônio Líquido em relação às diferenças entre as normas contábeis do Brasil e EUA 
Tabela 32 - COPEL - Reconciliação do Lucro Líquido em relação às diferenças entre as normas contábeis do Brasil e

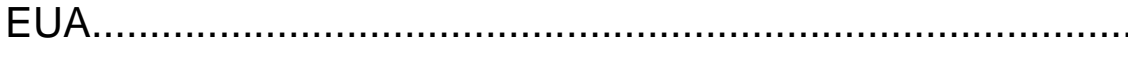

Tabela 33 - EMBRATEL- Balanço Patrimonial Consolidado em 31 de Dezembro de 1999...........................................................

Tabela 34 - EMBRATEL - Demonstração do Resultado para o Exercício findo em 31 de Dezembro de 1999.................

Tabela 35 - EMBRATEL - Conciliação do Lucro Líquido e do Patrimônio Líquido em 1999.

Tabela 36 - EMBRATEL - Reconciliação do Lucro Líquido e do Patrimônio Líquido em relação às diferenças entre as normas contábeis do Brasil e EUA. 


\section{RESUMO}

Desde 1996 companhias brasileiras vêm lançando títulos em bolsas de valores norte-americanas como uma forma de obter recursos financeiros. A Comissão de Valores Mobiliários dos EUA (SEC) requer dessas companhias a tradução de suas demonstrações contábeis para dólares e a sua apres.entação de acordo com os Princípios Contábeis Geralmente Aceitos nos EUA (US GAAP).

Conforme estipulam os pronunciamentos contábeis para a tradução de demonstrações financeiras em moeda estrangeira, o Brasil era considerado uma economia altamente inflacionária até julho de 1997, embora a Lei 9.249/95 tenha proibido que a partir de 1996 as companhias contabilizassem a correção monetária.

Este estudo apresenta uma análise comparativa entre as demonstrações contábeis feitas de acordo com a legislação societária brasileira e as demonstrações elaboradas com a utilização do método da correção integral, de 1996 a 1999, de algumas companhias brasileiras nesta situação, com o objetivo de demonstrar os efeitos da inflação neste período sobre a informação contábil.

O trabalho também identifica algumas das diferenças entre as práticas contábeis utilizadas no Brasil e aquelas recomendadas pelos US GAAP encontradas nas demonstrações contábeis analisadas.

Conclui-se que em 1996 e 1997 investidores brasileiros e norteamericanos tiveram acesso a informações diferentes, em função do uso da 
correção monetária neste período apenas nas demonstrações contábeis divulgadas nos EUA, e que a decisão de não mais utilizar a correção monetária acarretou perdas para as companhias e deteriorou a qualidade da informação contábil. 


\begin{abstract}
Since 1996 Brazilian Companies has issued stocks at American Stock Exchanges as a way to obtain financial resources. These companies are asked by the United States Securities and Exchange Commission (SEC) to translate their financial statements into American Dollars and present them in accordance with the Generally Accepted Accounting Principles in the USA (US GAAP).

As stipulated by the American accounting pronouncements for translation of financial statements into foreign currency, Brazil was considered a highly inflationary economy until July 1997, although the Law 9.249/95 had established that from 1996 on companies would no longer record monetary correction, an accounting technique designed to reflect the effects of inflation.
\end{abstract}

This study presents a comparative analysis among the financial statements in accordance with the Brazilian Corporate Law and the financial statements elaborated using the Constant Currency Method, from 1996 to 1999 , of some Brazilian Companies in this situation, with the objective of demonstrate the effects of inflation on this period upon accounting information.

It also identifies some of the differences between Brazilian accounting practices and those practices recommended by US GAAP found on the financial statements analyzed.

It concludes that in 1996 and 1997 Brazilian and American investors had access to different information, because of the use of monetary correction only on financial statements reported in the USA, and that the decision of ceasing the 
use of monetary correction has brought losses for the companies and impairment to the quality of accounting information. 


\section{INTRODUÇÃO}

Com a crescente globalização da economia, cada vez mais, companhias locais têm tido acesso ao mercado financeiro internacional, seja através da tomada de empréstimos externos ou do lançamento de títulos nas principais bolsas de valores do mundo.

Outra situação que já existe há muito tempo no mundo dos negócios é o fato de que grandes empresas têm se estabelecido em outros países através da aquisição de empresas locais ou mesmo da abertura de subsidiárias ou coligadas nesses países.

Como resultado dessa realidade surge para a Contabilidade a necessidade de superar as barreiras de linguagem, moeda e, principalmente, das diferenças existentes entre as práticas contábeis adotadas em cada país, de modo a possibilitar a compreensão e interpretação das demonstrações contábeis por investidores e pela matriz estrangeira.

Demonstrações contábeis preparadas em diferentes países que utilizam diferentes práticas contábeis têm apresentado diferentes resultados. Este foi o caso da empresa alemã Daimler-benz, que para negociar suas ações na Bolsa de Valores de Nova lorque, em 1993, precisou refazer seus demonstrações contábeis de acordo com as normas norte-americanas.

O resultado dessa mudança de critérios e práticas é que a empresa, que havia apresentado um lucro de 370 milhões de dólares norte-americanos, 
conforme as normas alemãs, apresentou um prejuízo de um bilhão de dólares de acordo com as normas norte-americanas ${ }^{1}$.

A partir desse exemplo é possível perceber que as práticas contábeis variam de país para país. As práticas contábeis da Alemanha, onde os banqueiros são os principais usuários da informação contábil, pelo fato de serem os principais fornecedores de capital para as empresas, são diferentes das práticas norte-americanas, onde a informação contábil é preparada principalmente para atender às necessidades de informação dos investidores.

Os Estados Unidos exercem forte influência no sentido de que os princípios contábeis geralmente aceitos naquele país (Generally Accepted Accounting Principles - US GAAP) sejam adotados por empresas estabelecidas em outros países para "traduzir" suas demonstrações financeiras a fim de tornálas inteligíveis em nível internacional.

Assim, as subsidiárias, controladas e coligadas de empresas norteamericanas localizadas fora dos EUA devem traduzir suas demonstrações financeiras, refazendo-as de acordo com os US GAAP, a fim de consolidá-las às da matriz ou controladora norte-americana.

Da mesma forma, as empresas estrangeiras que desejam negociar suas ações em bolsas de valores daquele país estão também obrigadas a fazer a referida tradução, adaptando-se aos padrões norte-americanos (US GAAP).

\footnotetext{
${ }^{1}$ CAUDRON, Shari. Expanding Horizons in Global Accounting. Controller Magazine, Nova lorque, NY, v.3, u.2, p.20-24, fev.1997.
} 
Nessa situação encontram-se algumas empresas brasileiras que, para lançar suas ações na Bolsa de Valores de Nova lorque, tiveram que adaptar sua contabilidade às normas norte-americanas (US GAAP). Esta é uma maneira eficiente e cada vez mais freqüente que as empresas encontraram para obter recursos para investimentos a custos menores do que se tivessem que recorrer a empréstimos. A Bolsa de Nova lorque movimenta diariamente mais de 40 bilhões de dólares, 150 vezes mais do que circula na Bolsa de Valores de São Paulo, a maior do Brasil².

Para efetuar a tradução de demonstrações contábeis em moedas estrangeiras para a moeda norte-americana, os Estados Unidos estabeleceram regras específicas para cada uma das situações abaixo ${ }^{3}$ :

a) investimento em dólar norte-americano em país de economia altamente inflacionária;

b) investimento em país de economia não inflacionária;

c) empresas estrangeiras que desejam lançar títulos no mercado daquele país.

O foco deste trabalho será a situação "c" anterior, pretende-se traduzir para dólares as demonstrações contábeis originais, de acordo com a legislação societária, assim como as demonstrações em moeda constante de algumas empresas brasileiras naquela situação, para em seguida comparar os dois

2 BAPTISTA, Cristina. Na Capital do Dinheiro. Revista Veja. ed. Abril. oํ 15, ano 34, p.110-111, 18.abr.2001.

${ }^{3}$ MARTINS, Eliseu. Conversão de Demonstrações Contábeis em Moeda Estrangeira - Introdução e "FAS8" (1a parte). Boletim IOB - Temática Contábil e Balanços. Bol. 24, 1995, p.218. 
conjuntos de demonstrações, a fim de evidenciar os montantes em dólares referentes às distorções causadas em função da inflação.

A metodologia a ser utilizada para o desenvolvimento do presente trabalho será a pesquisa empírica, na qual serão utilizados dados documentais secundários, que consistem nas demonstrações contábeis publicadas no período de 1996 a 1999, de acordo com as normas brasileiras e nas demonstrações publicadas de acordo com as normas norte-americanas (US GAAP), de algumas empresas brasileiras que vêm operando na Bolsa de Valores de Nova Iorque desde aquele período.

O tratamento dos dados ocorrerá da seguinte forma:

a) serão convertidas para dólares as demonstrações contábeis publicadas pelas empresas, tanto aquelas elaboradas de acordo com a legislação societária brasileira, sem considerar os efeitos da inflação, como as demonstrações em moeda constante, publicadas como informação complementar, relativas ao período de 1996 a 1999;

b) em seguida serão comparados os dois conjuntos de demonstrações em cada exercício, a fim de levantar as diferenças pelo não reconhecimento dos efeitos da inflação nas demonstrações elaboradas de acordo com a legislação societária brasileira;

c) serão ainda comparadas determinadas contas das demonstrações em dólares, obtidas a partir das traduções efetuadas, com as demonstrações publicadas nos EUA de acordo com os US GAAP, com o objetivo de evidenciar eventuais diferenças entre as práticas 
contábeis brasileiras e norte-americanas, com base nas informações prestadas pelas empresas em notas explicativas.

Dessa forma, o trabalho abordará as seguintes dimensões:

a) as distorções causadas pela inflação nas demonstrações contábeis de empresas brasileiras, caso não tivessem sido corrigidas monetariamente em 1996 e 1997 para fins de adaptação às normas norte-americanas (US GAAP);

b) as diferenças entre as práticas contábeis brasileiras e norteamericanas, objeto de ajustes para tradução das demonstrações contábeis das empresas analisadas.

O trabalho foi estruturado em quatro capítulos, da seguinte forma:

No capítulo 1 - Tradução de demonstrações contábeis para moeda estrangeira - são apresentados os diversos métodos utilizados para tradução de demonstrações contábeis de uma moeda para outra, os pronunciamentos divulgados pelo órgão norte-americano de normas contábeis (FASB), assim como as metodologias utilizadas no Brasil para a tradução de demonstrações contábeis para moeda estrangeira.

No capítulo 2 - Normas e práticas contábeis no Brasil e nos EUA apresenta-se os principais órgãos reguladores de normas contábeis no Brasil e nos EUA e as principais diferenças entre normas e práticas contábeis nos dois países.

No capítulo 3 - Histórico da Inflação no Brasil - é feita uma retrospectiva sobre a inflação no Brasil e seus efeitos sobre o poder aquisitivo da moeda, 
bem como os métodos de correção monetária utilizados ao longo do tempo para minimizar tais efeitos sobre as demonstrações contábeis.

No capítulo 4 - Análise dos Dados - são apresentadas as demonstrações contábeis traduzidas para dólares de algumas empresas brasileiras que estavam operando na Bolsa de Valores de Nova lorque no período de 1996 a 1999, traduzindo-se tanto as demonstrações feitas de acordo com a legislação societária como as demonstrações em moeda constante, com o objetivo de evidenciar eventuais distorções em função do não reconhecimento dos efeitos da inflação, para em seguida compará-las às demonstrações apresentadas aos investidores norte-americanos.

Por fim, serão apresentados os comentários finais e as conclusões obtidas ao longo deste trabalho. 


\section{CAPÍTULO 1}

\section{Tradução de demonstrações contábeis para moeda estrangeira}

A globalização da economia vem exigindo cada vez mais que empresas com negócios no exterior efetuem a tradução de suas demonstrações contábeis para moeda estrangeira, o que é feito, segundo Perez Júnior ${ }^{4}$, com os seguintes objetivos:

a) obter demonstrações contábeis em moeda constante, não sujeita aos efeitos da inflação;

b) permitir ao investidor estrangeiro melhor acompanhamento do seu investimento, já que as demonstrações convertidas estarão expressas na moeda corrente de seu próprio país;

c) possibilitar a aplicação do método de equivalência patrimonial sobre os investimentos efetuados em diversos países;

d) possibilitar a consolidação e combinação de demonstrações contábeis de empresas situadas em diversos países.

A tradução de demonstrações contábeis para uma moeda estrangeira é o processo pelo qual os valores de cada item dessas demonstrações são convertidos para uma outra moeda, com base em uma taxa de câmbio.

Alguns autores denominam esse processo como "conversão" de demonstrações contábeis, o qual é considerado por outros autores um termo

\footnotetext{
${ }^{4}$ PEREZ JÚNIOR, José Hernandez. Conversão de Demonstrações Contábeis para Moeda Estrangeira. Altlas, 4⿳亠丷厂 ed. 2001. p 50.
} 
inadequado, como é o caso de Choi e Mueller ${ }^{5}$, que a seguir definem os dois termos:

"Tradução não é sinônimo de conversão. Conversão é a troca física de uma moeda por outra. (...) Tradução é simplesmente uma troca da expressão monetária (...). Não ocorre troca física ou qualquer transação a ser contabilizada." (tradução livre)

Neste trabalho será utilizado o termo "tradução" para designar o processo acima definido, exceto nos casos de citações em que os autores utilizem o termo "conversão".

É importante também diferenciar a tradução de demonstrações contábeis para moeda estrangeira da contabilidade em moeda estrangeira, também conhecida como tradução das operações. De acordo com Perez Júnior ${ }^{6}$ :

"No caso de conversão de demonstrações contábeis, a empresa mantém sua contabilidade em moeda nacional (...) e somente ao final do exercício, após o encerramento das demonstrações em moeda nacional, aplica os procedimentos de conversão (...). No caso da contabilidade em moeda estrangeira, as operações são convertidas para moeda estrangeira à medida que ocorrerem e registradas em sistema contábil próprio, apurando ao término do exercício as demonstrações em moeda estrangeira, não havendo a necessidade de nenhuma conversão."

O foco deste trabalho será a tradução das demonstrações e não a tradução das operações, visto que tratará de empresas brasileiras, que mantêm sua contabilidade em Reais.

De um modo geral, existem vários métodos para se efetuar a tradução para moeda estrangeira, os quais definem a taxa de câmbio a ser utilizada e os

\footnotetext{
${ }^{5} \mathrm{CHOI}$, Frederick D. S; MUELLER, Gehard G. International Accounting. Prentice Hall, 2ª ed. 1992. p.139.

6 PEREZ JÚNIOR, José Hernandez. Conversão de Demonstrações Contábeis para Moeda Estrangeira. Atlas, 4ํaㄹ. ed. 2001. p 52.
} 
demais procedimentos para a tradução, de acordo com a base conceitual de cada um.

Muitos países estabelecem regras para a tradução, geralmente adotando um determinado método, como é o caso dos Estados Unidos. Outros países, como Alemanha e Suécia, aceitam regras diferentes, sem obrigar o uso de um método qualquer. ${ }^{7}$

A principal distinção entre os diversos métodos normativos de tradução é a exigência de traduzir particulares classificações de ativos e passivos ou à taxa corrente ou à taxa histórica.

Serão descritos a seguir os métodos de tradução mais conhecidos.

\subsection{Métodos de tradução para moeda estrangeira}

\subsubsection{Método temporal}

O método temporal traduz à taxa corrente da data do balanço os ativos e passivos escriturados a preços atuais ou futuros, como caixa, valores a receber e valores a pagar, e traduz às taxas históricas aplicáveis os ativos e passivos escriturados a preços passados, como os estoques, os ativos fixos e as receitas diferidas. A maioria das receitas e despesas é traduzida pela média das taxas de câmbio do período, sendo que a despesa de depreciação e o custo das

\footnotetext{
${ }^{7}$ MARTINS, Eliseu. Conversão de Demonstrações Contábeis em Moeda Estrangeira - Introdução e "FAS8". Boletim IOB - Temática Contábil e Balanços. Bol. 24, 1995. p.218.
} 
vendas são traduzidos à apropriada taxa histórica. Os ganhos ou perdas na tradução são levados diretamente ao resultado.

\subsubsection{Método monetário / não monetário}

O método monetário/não monetário traduz à taxa corrente os ativos e passivos monetários (realizáveis em moeda), como caixa, contas a receber e a pagar, e os ativos e passivos não monetários, como estoques, ativos fixos, receitas e despesas antecipadas, são traduzidos às taxas históricas aplicáveis.

Santos ${ }^{8}$ afirma que "os resultados deste método podem coincidir com os do método temporal". E acrescenta que "os resultados apresentados pelos dois métodos poderiam ser bem diferentes se os princípios contábeis exigissem medições diferentes dos preços de aquisição ou preços incorridos para os ativos e passivos monetários."

\subsubsection{Método corrente / não corrente}

O Método corrente/não corrente traduz os ativos e passivos correntes à taxa corrente e os ativos e passivos não correntes às taxas históricas aplicáveis. Dessa forma, itens não monetários como os estoques e receitas e despesas antecipadas são também traduzidos à taxa corrente, pelo fato de estarem classificados no Circulante, e as contas a receber e a pagar no longo

\footnotetext{
${ }^{8}$ SANTOS, Ariovaldo dos. Aspectos da Conversão de Demonstrações Financeiras para Moeda Estrangeira. Dissertação de Mestrado. FEA-USP. 1980. pp.10 e 11.
} 
prazo são traduzidas às taxas históricas respectivas, por não estarem no Circulante.

\subsubsection{Método da taxa corrente}

O método corrente é o mais fácil de ser aplicado, uma vez que traduz todos os ativos e passivos à taxa corrente de câmbio do final do período apresentado, mas pode apresentar resultados totalmente distorcidos quando aplicado em países com significativas variações nas taxas de câmbio.

\subsection{Pronunciamentos do FASB}

O Financial Accounting Standards Board - FASB (Comitê de Normas Contábeis) é o principal órgão de normatização contábil nos Estados Unidos. Suas atividades foram iniciadas em junho de 1973, com grande apoio financeiro do Governo Federal daquele país, das entidades de classe da profissão contábil e de grandes empresas. Sua função é estabelecer e aperfeiçoar normas de contabilidade financeira e de relatório aplicáveis às companhias de capital aberto e fechado, exceto entidades governamentais estaduais e municipais. Tais normas são denominadas Statement of Financial Accounting Standards SFAS, que serão aqui mencionadas como pronunciamentos.

O FASB já emitiu dois pronunciamentos sobre a tradução de demonstrações contábeis de acordo com as normas norte-americanas: o SFAS ํo 8 - Accounting for the Translation for Foreign Currency Transactions and Foreign Currency Financial Statements (Contabilidade para a Tradução de 
Transações em Moeda Estrangeira e Demonstrações Financeiras em Moeda Estrangeira), emitido em 1975; e o SFAS no 52 - Foreign Currency Translation (Tradução em Moeda Estrangeira), emitido em 1981.

O SFAS $\mathrm{n}^{\circ}$ 8, que utilizava o método temporal, identificou duas categorias de taxas de tradução: as taxas históricas e as taxas correntes, que devem representar as mesmas taxas utilizadas pelo país para a remessa de dividendos ou retorno de capital estrangeiro (taxa de câmbio de venda).

Assim, foram adotadas pelo SFAS no 8 as seguintes taxas para tradução de ativos e passivos, conforme tabela a seguir:

\begin{tabular}{|c|c|c|}
\hline & $\begin{array}{c}\text { Taxa } \\
\text { Corrente }\end{array}$ & $\begin{array}{c}\text { Taxa } \\
\text { Histórica }\end{array}$ \\
\hline \multicolumn{3}{|l|}{ ATIVO } \\
\hline $\begin{array}{l}\text { Caixa e Bancos } \\
\text { Títulos negociáveis: } \\
\text { - Ao custo } \\
\text { - Ao preço de mercado corrente } \\
\text { Contas e títulos a receber e respectivas deduções } \\
\text { Provisão para devedores duvidosos } \\
\text { Inventários: } \\
\text { - Ao custo } \\
\text { - Ao custo de reposição corrente ou preço de venda } \\
\text { - corrente } \\
\text { - Ao valor realizável líquido } \\
\text { - Ao preço de contrato (produzidos sob contratos de } \\
\text { preço fixo) } \\
\text { Seguros antecipados, publicidade e aluguel } \\
\text { Adiantamento e cauções } \\
\text { Imobilizado técnico } \\
\text { Depreciação acumulada do imobilizado técnico } \\
\text { Valor de resgate de seguro de vida } \\
\text { Patentes, marcas registradas, licenças, fórmulas } \\
\text { Fundo de comércio } \\
\text { Outros ativos intangíveis }\end{array}$ & $\begin{array}{l}X \\
X \\
X\end{array}$ & $\begin{array}{l}X \\
X \\
X \\
X \\
X \\
X \\
X\end{array}$ \\
\hline
\end{tabular}




\section{Taxa Taxa Corrente Histórica}

\section{PASSIVO}

Contas e títulos a pagar e saques a descoberto Despesas a pagar acumuladas

Prejuízos acumulados sobre contratos firmes de compra

Cauções

Receitas diferidas

Obrigações a pagar e outras dívidas a longo prazo

Ágios ou descontos a amortizar sobre obrigações ou títulos a pagar

Obrigações conversíveis a pagar

Obrigações acumuladas sobre planos de pensão Obrigações por garantias

Fonte: SFAS $N^{\circ} 08$ - Accounting for the Translation for Foreign Currency Transactions and Foreign Currency Financial Statements ${ }^{9}$

De acordo com Martins ${ }^{10}$, são empregados os seguintes critérios pelo SFAS no 8 na tradução dos itens da Demonstração do Resultado:

- São desprezados todos os efeitos da correção monetária de balanço;

- Faz-se a conversão das receitas e despesas pelas suas datas de formação, aceitando-se o uso de valores médios para o período quando isso não trouxer distorções relevantes;

- Depois se introduz a figura dos "Ganhos ou Perdas na Conversão.

O mesmo autor afirma em seguida que a filosofia básica desse método é a de que "as Demonstrações Contábeis convertidas são aquelas que seriam

\footnotetext{
${ }^{9}$ Financial Accounting Standards Board. Statement of Financial Accounting Standards $N^{\circ} 08-$ Accounting for the Translation for Foreign Currency Transactions and Foreign Currency Financial Statements. In: Conversão de Balanços em Moeda Estrangeira, 1998. São Paulo. JCA Treinamentos.

${ }_{10}$ MARTINS, Eliseu. Conversão de Demonstrações Contábeis em Moeda Estrangeira - Introdução e "FAS-8". Boletim IOB - Temática Contábil e Balanços. Bol. 24, 1995. p.214.
} 
obtidas caso a Contabilidade fosse efetuada por um Contador norte-americano, localizado nos EUA, seguindo os preceitos contábeis de lá."

O SFAS no 52 revogou o SFAS no 8 e estabeleceu duas modalidades de critérios para a tradução das demonstrações contábeis, de acordo com a situação econômica do país em que a empresa estiver localizada, conforme a seguir:

a) economias consideradas estáveis (não hiperinflacionárias);

b) economias consideradas hiperinflacionárias, definidas como economias cujo efeito cumulativo da inflação em três anos consecutivos se aproxima ou supera a marca de $100 \%$, para as quais se aplicam os critérios de tradução estabelecidos pelo SFAS no 8.

O SFAS $n^{\circ} 52$, embora tenha revogado o SFAS $n^{\circ}$ 8, manteve os critérios existentes naquele pronunciamento para a tradução de demonstrações contábeis em economias consideradas hiperinflacionárias, que adota o método temporal. Dessa forma, foi modificada somente a norma aplicável a países de economia estável, passando a adotar o método da taxa corrente para esses casos.

O SFAS n 52 também introduziu o conceito de moeda funcional, que é definida pelo pronunciamento do FASB como "a moeda do ambiente econômico primário no qual a entidade opera (FAS52, §5)" (tradução livre). O FASB 
estabeleceu ainda alguns fatores determinantes para a escolha da moeda funcional ${ }^{11}$ :

1. Indicadores de fluxos de caixa - se os fluxos de caixa da entidade estrangeira afetarem diretamente os fluxos de caixa da matriz, deve-se usar a moeda da matriz como moeda funcional; do contrário, deve ser usada a moeda local;

2. Indicadores de preços de venda - será utilizada a moeda da matriz como funcional se os preços da entidade forem influenciados por taxas de câmbio ou por concorrência internacional; será utilizada a moeda local como funcional quando os preços dependerem de concorrência local;

3. Indicadores do mercado de vendas - se o mercado de vendas for principalmente o da matriz deve ser utilizada a moeda da matriz como funcional; se o mercado de vendas for o local, a moeda local será usada como funcional;

4. Indicadores de despesas - se as despesas forem incorridas basicamente no país da matriz, deve-se utilizar a moeda deste país como funcional; do contrário, utiliza-se a moeda local como funcional;

5. Indicadores de financiamento - se a empresa é financiada basicamente pela matriz ou se seus financiamentos são obtidos em

${ }^{11}$ Delaney, Patrick R. et. al. GAAP 2000. Interpretation and Aplication of Generally Accepted Accounting Principles. John Villey and Sons, Inc. 2000. p.802. 
moeda da matriz, será utilizada esta moeda como funcional; se, por outro lado, a empresa não depende de financiamentos da matriz, a moeda local será utilizada como funcional;

6. Indicadores de transações intercompanhias - se houver um alto volume de transações intercompanhias entre a matriz e a entidade estrangeira deve ser utilizada a moeda da matriz como funcional; do contrário, a moeda local será utilizada como moeda funcional.

Com base nos mencionados indicadores, analisados de forma individual ou coletivamente, a administração deve decidir qual a moeda funcional a ser utilizada, se a moeda da matriz ou a moeda local.

É também necessário definir o que vem a ser a "moeda de relatório", que é a moeda na qual as demonstrações contábeis são apresentadas. Para melhor entendimento de tais conceitos, apresenta-se o exemplo citado por Perez Júnior ${ }^{12}$ :

"Uma empresa inglesa mantém suas principais operações com uma empresa alemã. Assim teremos:

Moeda local: Libra Esterlina

Moeda funcional: Marco Alemão

Moeda de relatório: Dólar Americano"

Em uma situação como a do exemplo citado, em que a moeda local é diferente da moeda funcional, a tradução da moeda local para a moeda funcional deve ser feita utilizando-se o método temporal, enquanto que a

12 PEREZ JÚNIOR, José Hernandez. Conversão de Demonstrações Contábeis para Moeda Estrangeira. Atlas, 4⿳亠丷厂 ed. 2001. p 150. 
tradução da moeda funcional para a moeda de relatório deve seguir o método da taxa corrente.

Dessa forma, a utilização da moeda local como moeda funcional facilita o trabalho da tradução das demonstrações contábeis, visto que será utilizado somente o método da taxa corrente. No entanto, tal decisão deve respeitar a análise dos fatores já mencionados para definir a moeda funcional mais adequada a cada empresa. Além disso, no caso de entidades localizadas em economias altamente inflacionárias, o FASB considera que a moeda local não pode ser usada como funcional. Neste caso, as demonstrações contábeis devem ser traduzidas como se a moeda funcional fosse a moeda de relatório.

O SFAS no 52 estabelece que os ajustes na tradução não devem ser incluídos na determinação do lucro líquido, mas divulgados separadamente como um componente do patrimônio líquido. Sobre o assunto, Perez Júnior ${ }^{13}$ faz o seguinte comentário, onde diferencia os ajustes na tradução dos ganhos ou perdas na conversão:

- "ajustes de tradução: são decorrentes de diferença de taxa cambial entre a moeda funcional e a moeda de relatório. Ocorre quando a moeda funcional é diferente da moeda de relatório;

- ganhos ou perdas: são decorrentes de diferença de taxa cambial entre a moeda local e a moeda funcional. Ocorrem quando a moeda funcional é diferente da moeda local."

${ }^{13}$ PEREZ JÚNIOR, José Hernandez. Conversão de Demonstrações Contábeis para Moeda Estrangeira. Atlas, $4^{\mathrm{a}}$ ed. 2001. p 152. 
Natal ${ }^{14}$ resume os critérios de tradução estabelecidos pelo SFAS no 52 conforme a seguir:

- "Se a contabilidade é mantida em moeda local (...) e conclui-se que a moeda funcional é a própria moeda local, utilizar-se-á o método corrente para efetuar a tradução das demonstrações em moeda local para dólar.

- Se a contabilidade é mantida em moeda local, porém conclui-se que a moeda funcional é uma terceira moeda, far-se-á primeiramente a conversão das demonstrações em moeda local para a moeda funcional através do método temporal e em seguida utilizar-se-á o método corrente para efetuar a tradução das demonstrações obtidas em moeda funcional para dólar.

- Se a contabilidade é mantida em moeda local, porém conclui-se que a moeda funcional é o dólar, far-se-á a tradução das demonstrações em moeda local para dólar pelo método temporal."

De acordo com Martins ${ }^{15}$ a filosofia do SFAS no 52 é a seguinte:

"O FAS-52 parte do seguinte raciocínio: as demonstrações feitas na moeda local, se dentro dos critérios e das normas norte-americanas, estão melhor preparadas nessa moeda do que se fosse efetuada a conversão com base nas taxas históricas de formação dos itens nãomonetários (que é a base da lógica do FAS-8)."

O FASB estabelece no SFAS no 52 que a tradução de demonstrações financeiras de uma moeda para outra, para outros propósitos que não o de consolidação, combinação ou aplicação do método de equivalência patrimonial está fora do escopo deste pronunciamento, como é o caso de empresas que efetuam a tradução de suas demonstrações financeiras para a conveniência de

\footnotetext{
14 NATAL, Lairton. Tradução Monetária das Demonstrações Financeiras para Moeda Estrangeira. Dissertação de Mestrado. São Paulo: FEA-USP, 1988. p. 42.

${ }^{15}$ MARTINS, Eliseu. Conversão de Demonstrações Contábeis em Moeda Estrangeira - O "FAS-52" (1"a parte). Boletim IOB - Temática Contábil e Balanços. Bol. 30, 1995. p.278.
} 
leitores acostumados a uma outra moeda (SFAS-52, §2). Estabelece ainda que a tradução das demonstrações financeiras tem por objetivo: ${ }^{16}$

“a) Fornecer informações que sejam geralmente compatíveis com os efeitos econômicos esperados de uma alteração de taxa de câmbio sobre os fluxos de caixa e o patrimônio líquido de uma empresa

c) Refletir nas demonstrações consolidadas o resultado financeiro e o relacionamento das entidades individuais, consolidadas como medidos em suas moedas funcionais, em conformidade com os princípios contábeis geralmente aceitos nos Estados Unidos (SFAS-52, §4)”.

Dessa forma, deve-se ressaltar que, se o propósito para o qual esteja sendo efetuada a tradução das demonstrações contábeis for o de consolidação, combinação ou aplicação do método de equivalência patrimonial, faz-se necessária, antes da tradução, a adaptação das práticas contábeis utilizadas para a preparação destas demonstrações aos critérios exigidos pelos princípios contábeis geralmente aceitos nos Estados Unidos (United States Generally Accepted Accounting Principles - US GAAP).

Segundo Perez Júnior ${ }^{17}$ :

"Quando o objetivo da conversão das demonstrações contábeis é a obtenção de recursos no exterior ou para apresentação a investidores, não há a obrigatoriedade de aplicação dos procedimentos de conversão previstos no FAS-52, a menos que haja exigência específica por parte do credor ou investidor."

Ainda sobre o assunto, Martins ${ }^{18}$ coloca que:

"Se uma empresa vai lançar títulos no mercado norte-americano, por exemplo, há situações em que pode se tratar de colocações

\footnotetext{
${ }^{16}$ Financial Accounting Standards Board. Statement of Financial Accounting Standards $N^{\circ} 52$ Foreign Currency Translation. Current Text - Accounting Standards as of june 1, 1995. Vol. I. John Villey and Sons, Inc.

${ }^{17}$ PEREZ JÚNIOR, José Hernandez. Conversão de Demonstrações Contábeis para Moeda Estrangeira. Atlas, $4^{\text {a }}$ ed. 2001. p 53.

${ }^{18}$ MARTINS, Eliseu. Conversão de Demonstrações Contábeis em Moeda Estrangeira - Introdução e "FAS-8". Boletim IOB - Temática Contábil e Balanços. Bol. 27, 1995. p.247.
} 
fechadas, não públicas, não são pedidas demonstrações convertidas, nem demonstrações elaboradas à base dos procedimentos daquele país; mas, no caso de lançamento primário ou público normalmente se exige a re-elaboração das demonstrações conforme a Contabilidade de lá."

Muitas empresas brasileiras têm suas ações negociadas nas bolsa de valores norte-americanas através de um instrumento denominado "American Depositary Receipt - ADR", que é um certificado emitido por bancos norteamericanos, representativo de ações dessas empresas, mantidas em custódia em um banco brasileiro.

De acordo com Andrezo e Lima ${ }^{19}$ há três níveis de ADR, que diferem quanto ao modo de negociação e às exigências de adequação às normas da Comissão de Valores Mobiliários dos EUA (Securities and Exchange Commission - SEC), conforme a seguir:

- “ADR nível I (pink sheet): neste nível ocorre apenas a conversão em ADRs de ações da empresa já negociadas no mercado secundário brasileiro, e a subseqüente negociação dos ADRs em mercado de balcão norte-americano (OTC), via terminal de computador. Como as ações que vão lastrear os ADRs já devem existir no mercado secundário, não há captação de recursos novos pela empresa emissora, mas apenas uma troca de propriedade de seus papéis. As formalidades junto à SEC consistem apenas em (i) fornecer aos investidores americanos as mesmas informações disponíveis no mercado brasileiro e (ii) solicitar o pedido de isenção de registro a esse órgão. Além disso há a necessidade de estabelecer um Depositary Agreement entre a empresa brasileira e o banco depositário norte-americano e atender algumas exigências da CVM e Banco Central. Não há, entretanto, a necessidade de adaptação da contabilidade aos padrões americanos. Esse é o programa mais simples e o mais comum, que tem a vantagem de ser mais barato do que os outros, além de dar liquidez à ação e ampliar sua base de acionistas. No

19 ANDREZO, Andrea Fernandes; LIMA, Iran Siqueira. Mercado Financeiro - Aspectos Históricos e Conceituais. 2. ed. São Paulo: Pioneira Thomson Learning, 2002, p.212. 
entanto, há limitações pelo fato de que as negociações ocorrem apenas no mercado de balcão.

- $\quad \boldsymbol{A D R}$ nível II (lister): também não permite a captação de recursos novos, mas autoriza a empresa a se listar nas bolsas americanas, tais como: NYSE (New York Stock Exchange) e NASDAQ (National Association of Securities Dealers Automated Quotation), acarretando as seguintes exigências: (i) registro completo na SEC, (ii) registro em bolsa norte-americana, (iii) adaptação das demonstrações contábeis da empresa aos USGAAP e (iv) fornecimento periódico de informações detalhadas aos investidores. O processo mais demorado e custoso consiste na adequação das últimas demonstrações contábeis da empresa aos USGAAP, o que demora de três a seis meses, pois é preciso discutir alguns itens de forma bem aprofundada, como fundos de pensão e contingências.

- ADR nível III (fully registered): permite a efetiva oferta pública de ADRs da empresa no mercado norte-americano, pois ocorre emissão de novas ações ou distribuição secundária. Por causa disso, há a necessidade de registro completo à SEC, nos termos do Securities Act of 1933, e adaptação das demonstrações contábeis aos USGAAPS. O procedimento de registro na SEC é semelhante, mas mais completo do que aquele necessário para o nível II. Os custos legais para a elaboração do prospecto de venda, registro na SEC e na bolsa e as comissões de underwriters podem ser significativos."

Assim, a SEC tem exigido das empresas brasileiras que desejam lançar ADRs níveis II e III nas bolsas de valores daquele país, a tradução de suas demonstrações contábeis de acordo com o SFAS № 52, inclusive adaptando-as aos critérios contábeis estabelecidos pelos US GAAP.

Até $1^{\circ}$ de julho de 1997 o Brasil era considerado um país de economia altamente inflacionária, devendo observar os procedimentos do SFAS ํ 8 para conversão de demonstrações contábeis para a moeda norte-americana. A partir dessa data a economia brasileira passou a ser considerada de baixa inflação, passando às regras do SFAS no 52. 


\subsection{Os Métodos de tradução de demonstrações contábeis para moeda estrangeira utilizados no Brasil}

A adoção no Brasil da técnica da Correção Integral das demonstrações contábeis foi instituída pela Comissão de Valores Mobiliários (CVM) através da Instrução no 64/87. Posteriormente, outros normativos foram emitidos pela CVM no sentido de aperfeiçoar a sistemática de Correção Integral, até que em 1992 foi emitida a Instrução no 191, que consolidou as normas sobre o assunto.

A Correção Integral reconhece o efeito das mudanças dos níveis gerais de preços individualmente sobre as contas das demonstrações contábeis. Além de reconhecer os efeitos da inflação, essa técnica também aplica o conceito de ajuste a valor presente para compras e vendas a prazo e prefixadas, com base na taxa de juros divulgada pela ANBID (Associação Nacional dos Bancos de Investimento). Assim, a aplicação da Correção Integral veio, sem dúvida, melhorar a qualidade das demonstrações contábeis apresentadas no Brasil.

O uso generalizado dessa técnica, que era obrigatório para as sociedades por ações de capital aberto, fez com que surgissem formas alternativas de tradução das demonstrações contábeis para moeda estrangeira.

Foi assim que surgiu o "Método Brasileiro" de tradução de demonstrações contábeis para moeda estrangeira. Este método consiste em converter de forma direta para dólares todos os saldos do balanço, já ajustados pela metodologia da Correção Integral, com base na paridade do dólar norteamericano do final do exercício. 
Segundo Martins ${ }^{20}$ esse método é de fácil aplicação, porém o problema da não-paridade entre o dólar e a UFIR (Unidade Fiscal de Referência) ${ }^{21}$, ao longo do ano, pode causar as seguintes dificuldades:

- A não-cumulatividade dos valores em dólar;

- A não-conciliação entre valores de balanço de um ano para o outro; e

- A não-conferência com os registros da empresa de exportação ou importação.

Uma outra alternativa de tradução das demonstrações contábeis para moeda estrangeira utilizada no Brasil tem sido a aplicação do SFAS no 52 às demonstrações contábeis elaboradas pela Correção Integral em UFIR. Para tal, deve-se considerar a UFIR como a moeda funcional das demonstrações. Assim, a tradução seria feita do Real (moeda local) para a UFIR (moeda funcional), de acordo com as regras da Correção Integral, que se assemelham ao método temporal, e em seguida seria feita a conversão da UFIR para o dólar (moeda de relatório) pelo método da taxa corrente.

A diferença entre esse método, denominado "FAS-52 Correção Integral", e o "Método Brasileiro", é que este parte das demonstrações elaboradas pela Correção Integral em moeda da data do balanço, enquanto que o primeiro parte

\footnotetext{
${ }^{20}$ MARTINS, Eliseu. O "Método Brasileiro" de Conversão de Demonstrações Contábeis em Moeda Estrangeira (1a parte). Boletim IOB - Temática Contábil e Balanços. Bol. 42, 1995. p.386.

${ }^{21}$ A UFIR era o índice utilizado para atualização monetária de tributos e respectivas multas, bem como para corrigir as demonstrações contábeis pela técnica da Correção Integral.
} 
do dólar médio do período. Martins ${ }^{22}$ diferencia os dois métodos conforme a seguir:

"Na forma do 'FAS-52' Correção Integral cada receita ou despesa está em função da taxa de câmbio de sua origem, e a diferença daí para frente em termos da disparidade UFIR/dólar está na conta de Ajuste Especial, no Patrimônio Líquido. Na forma do 'Método Brasileiro' as receitas e despesas são trazidas para moeda de final de ano para só daí serem convertidas."

Mesmo após 1995, quando a Lei 9.249/95, em seu art. $4^{\circ}$, parágrafo único, vetou a utilização de qualquer sistema de correção monetária de demonstrações contábeis, inclusive para fins societários, a Correção Integral continuou sendo utilizada para fins de tradução dessas demonstrações, visto que neste período o Brasil ainda era considerado um país de economia altamente inflacionária, do ponto de vista dos critérios norte-americanos e internacionais, também aceitos pelo Conselho Federal de Contabilidade, que consideram como tal, as economias cujo efeito cumulativo da inflação em três anos consecutivos se aproxima ou supera a marca de $100 \%$.

A partir de $1^{\circ}$. de julho de 1997 o Brasil passou a ser considerado uma economia de baixa inflação, pois apresentou um índice acumulado de inflação inferior a $100 \%$ nos últimos 3 anos, o que permitia o uso do Real como moeda funcional, pelos critérios do SFAS ํㅜㄴ.

No encontro de 2 de dezembro de 1997, da Força Tarefa de Práticas Internacionais (International Practices Task Force) do Instituto Americano de

${ }^{22}$ MARTINS, Eliseu. O "Método Brasileiro" de Conversão de Demonstrações Contábeis em Moeda Estrangeira (3르 e última parte). Boletim IOB - Temática Contábil e Balanços. Bol. 44, 1995. p.405. 
Contadores Públicos Certificados (American Institute of Certified Public Accountants - AICPA), foi apresentada a seguinte orientação, baseada em discussões anteriores com a Comissão de Valores Mobiliários dos EUA (Securities and Exchange Commission - SEC) ${ }^{23}$ :

"As entidades devem avaliar as taxas históricas de inflação e suas tendências, bem como outros fatores para determinar se o Brasil é uma economia altamente inflacionária. Se concluir que a economia não é mais altamente inflacionária, as entidades brasileiras precisarão mensurar suas demonstrações financeiras usando a moeda funcional da entidade. Não é apropriado postergar a mudança da moeda funcional, uma vez que a administração tenha determinado que o Brasil não é mais uma economia altamente inflacionária." (tradução livre)

No encontro de 21 de novembro de 2000, da Força Tarefa de Práticas Internacionais, cujas orientações foram revisadas em 9 de abril de 2001, foi discutida a diferença entre as demonstrações contábeis preparadas de acordo com a legislação societária brasileira, daquelas preparadas em conformidade com os US GAAP, uma vez que as primeiras consideraram os efeitos inflacionários somente até 31 de dezembro de 1995 e estas últimas poderiam incluir até dois anos a mais (1996 e 1997) nos quais foram considerados os efeitos da inflação.

Em função dessa circunstância, a data em que os ativos e passivos nãomonetários foram "congelados" nas demonstrações em US GAAP difere das demonstrações preparadas em conformidade com a legislação societária brasileira ${ }^{24}$.

\footnotetext{
${ }^{23}$ AICPA SEC Regulations Committee Highlights - International Practices Task Force - Washington Office, December 2, 1997. Disponível: Site do AICPA. URL: http://www.aicpa.org. Consulta: 22/04/2002).

${ }^{24}$ AICPA SEC Regulations Committee Highlights - International Practices Task Force - Washington Office, November 21, 2000. Disponível: Site do AICPA. URL: http://www.aicpa.org. Consulta: 22/04/2002).
} 
Em suma, a partir de 1998, as empresas brasileiras passaram a não mais considerar os efeitos inflacionários em suas demonstrações contábeis traduzidas para o dólar norte-americano e em conformidade com as práticas contábeis dos EUA (US GAAP), enquanto que nos exercícios de 1996 e 1997 tais efeitos foram reconhecidos nas demonstrações em US GAAP e não reconhecidos nas demonstrações divulgadas no Brasil, de acordo com a legislação societária. 


\section{CAPÍTULO 2}

\section{Normas e práticas contábeis do Brasil e dos EUA}

Ao longo do tempo a Contabilidade vem evoluindo de acordo com o avanço econômico e social da humanidade. ludícibus ${ }^{25}$ afirma:

"A Contabilidade é uma ciência essencialmente utilitária, no sentido de que responde, por mecanismos próprios, a estímulos dos vários setores da economia. Portanto, entender a evolução das sociedades, em seus aspectos econômicos, dos usuários da informação contábil, em suas necessidades informativas, é a melhor forma de entender e definir os objetivos da Contabilidade".

A partir dessa afirmação, é possível entender porque os procedimentos contábeis variam de um país para o outro. Como qualquer ciência social, a Contabilidade sofre influências de ordem econômica, política e cultural, de modo que cada sociedade vem estabelecendo seus padrões e normas contábeis conforme suas necessidades locais.

Assim, a Contabilidade vem sendo regulada por princípios e normas produzidas por entidades governamentais ou representativas da profissão contábil. A seguir serão citadas algumas dessas entidades e suas funções, bem como a influência que cada uma exerce na produção de normas contábeis no Brasil e nos Estados Unidos.

${ }^{25}$ IUDíCIBUS, Sérgio de. Teoria da Contabilidade. 6.ed. São Paulo: Atlas, 2000, p.44. 


\section{1 Órgãos emissores de normas contábeis no Brasil}

\subsubsection{Conselho Federal de Contabilidade - CFC}

O CFC é uma autarquia federal criada pelo Decreto-lei no 9.295, de 27 de maio de 1946, a quem cabe o registro e a fiscalização dos profissionais da contabilidade. É um dos órgãos produtores de normas contábeis no Brasil, tendo emitido os Princípios Fundamentais de Contabilidade (Resolução no 750/93) e as Normas Brasileiras de Contabilidade (Resolução ํo 751/93), através do Grupo de Trabalho das Normas Brasileiras de Contabilidade, e posteriormente, a Resolução ํㅗ 900/01, que dispõe sobre a aplicação o Princípio da Atualização Monetária.

\subsubsection{Instituto dos Auditores Independentes do Brasil - IBRACON}

O IBRACON é uma entidade profissional que congrega contadores de diferentes áreas com interesse no estudo técnico da contabilidade, na edição de normas técnicas de contabilidade e auditoria e no aprimoramento da profissão no Brasil. Foi fundado em 13 de dezembro de 1971, sob a denominação de Instituto dos Auditores Independentes do Brasil - IAIB, através da fusão do Instituto dos Contadores Públicos do Brasil - ICPB e do Instituto Brasileiro de Auditores Independentes - IBAI, tendo assumido a denominação "Instituto Brasileiro de Contadores - IBRACON" em 1 de julho de 1982, com a 
alteração estatutária que permitiu maior abrangência de atuação e de interesses. A partir de 08 de junho de 2001 voltou a utilizar a denominação original, mantendo a sigla IBRACON.

Embora o IBRACON não tenha a atribuição de normatização legal dos procedimentos contábeis, alguns de seus pronunciamentos foram oficializados pela Comissão de Valores Mobiliários e pelo Banco Central do Brasil, tornando a sua observância obrigatória.

\subsubsection{Comissão de Valores Mobiliários - CVM}

A CVM é uma entidade autárquica criada pela Lei 6.385 , de 07 de dezembro de 1976, com a finalidade de disciplinar, fiscalizar e promover o desenvolvimento do mercado de valores mobiliários no Brasil. Tem o poder de emitir normas que abrangem as companhias abertas, tanto relacionadas a procedimentos contábeis, quanto ao controle do exercício profissional da auditoria no mercado de capitais.

\subsubsection{Banco Central do Brasil - BACEN}

O BACEN foi criado pela Lei 4.595 , de 31.12 .1964 , e iniciou suas atividades em 31 de março de 1965. Dentre suas funções de controle e regulamentação do Sistema Financeiro Nacional está a de regulamentação do 
funcionamento das instituições financeiras. Neste sentido, sob as diretrizes do Conselho Monetário Nacional, o Banco Central expede normativos como resoluções, circulares e outros documentos, consolidando-os em manuais tais como o Manual de Normas e Instruções (MNI), o Manual de Crédito Rural (MCR), a Consolidação das Normas Cambiais (CNC) e o Plano Contábil das Instituições do Sistema Financeiro Nacional (COSIF), este último consolidando as normas contábeis aplicáveis às instituições financeiras.

\section{2 Órgãos emissores de normas contábeis nos Estados Unidos}

\subsubsection{American Institute of Certified Public Accountants - AICPA}

O AICPA emitiu pronunciamentos sobre contabilidade entre 1938 e 1958, tendo sido uma das entidades que mais se destacaram nos Estados Unidos no estabelecimento de normas contábeis. Entre 1959 e 1973 os pronunciamentos passaram a ser emitidos pelo Accounting Principles Board - APB, órgão

vinculado ao AICPA. A partir de 1973, o AICPA designou o FASB e o GASB como os órgãos oficiais para estabelecer normas de acordo com o Código de Conduta Profissional do AICPA (AICPA's Code of Professional Conduct).

Atualmente o AICPA emite, com a concordância do FASB, pronunciamentos sobre princípios de contabilidade em ramos de negócios específicos (Statements of Position - SOPs), através de seu Comitê Executivo de Normas Contábeis. 


\subsubsection{Financial Accounting Standards Board - FASB}

O FASB é o principal órgão de normatização contábil nos Estados Unidos. Suas atividades foram iniciadas em junho de 1973, com grande apoio financeiro do Governo Federal, das entidades de classe da profissão contábil e de grandes empresas. Sua função é estabelecer e aperfeiçoar normas de contabilidade financeira e de relatório aplicáveis às companhias de capital aberto e fechado, exceto entidades governamentais estaduais e municipais.

\subsubsection{Governmental Accounting Standards Board - GASB}

O GASB estabelece normas de contabilidade financeira e de relatório para as entidades governamentais estaduais e municipais.

\subsubsection{Securities and Exchange Commission - SEC}

A SEC é um órgão governamental norte-americano equivalente à CVM no Brasil. É responsável pela fiscalização do mercado de títulos e tem autoridade para estabelecer a forma, o conteúdo e os requisitos das demonstrações contábeis de companhias de capital aberto. Embora também possa estabelecer normas contábeis, a SEC geralmente não exerce essa autoridade, delegando-a ao FASB. Suas publicações limitam-se à interpretação e ao esclarecimento de normas. 


\subsection{Comparação das normas e práticas contábeis}

No artigo "Os Grandes Modelos Contabilísticos", Mota ${ }^{26}$ observa que existem diferenças em aspectos relevantes na Contabilidade, da forma como é praticada de país para país, e que essas diferenças são de tal modo marcadas que permitem a sistematização de distintas categorias, que classifica nos seguintes modelos contábeis:

a) Modelo Britânico;

b) Modelo dos E.U.A.;

c) Modelo da Europa Latina;

d) Modelo da Europa do Norte;

e) Modelo da União Soviética.

O modelo contábil dos E.U.A. foi, a princípio, influenciado pelo modelo britânico. No entanto, com o grande desenvolvimento do mercado de capitais, aquele país passou a criar seu próprio modelo, orientado para a proteção dos investidores.

A crise do mercado de ações em 1929 levou à criação da SEC (Securities and Exchange Commission) em 1934, com a missão de supervisionar o processo de divulgação de informações financeiras.

Para exercer essa função, a SEC necessitava de uniformidade de procedimentos contábeis, o que não existia na época. Assim, a SEC pressionou

\footnotetext{
${ }^{26}$ MOTA, Rui. Os Grandes Modelos Contabilísticos. In: Jornal do Técnico de Contas e da Empresa n 294 , Portugal, p.41-42, fev.1990.
} 
o AICPA (American Institute of Certified Public Accountants) no sentido de fixar padrões de normas contábeis a serem usados obrigatoriamente pelas empresas $^{27}$.

Surge a partir desse momento a preocupação em fixar normas contábeis, tendo os E.U.A. criado um arcabouço de normas e padrões contábeis denominados "Princípios Contábeis Geralmente Aceitos" (Generally Accepted Accounting Principles - GAAP), também conhecidos como "US GAAP".

Essas normas foram criadas ao longo do tempo por diversos comitês e conselhos ligados ao AICPA e, desde 1973, o FASB (Financial Accounting Standards Board), órgão independente do AICPA, passou a ser responsável pela emissão de normas contábeis nos EUA: os US GAAP.

Os US GAAP são considerados normas contábeis evoluídas e têm grande aceitabilidade internacional como padrão para a tradução de demonstrações contábeis, visto que até mesmo alguns investidores estrangeiros não norte-americanos solicitam a adequação a essas normas.

A seguir, serão comparados alguns aspectos das normas contábeis norte-americanas (US GAAP) e das normas contábeis brasileiras.

${ }^{27}$ HENDRIKSEN, Eldon S. \& VAN BREDA, Michael F. Teoria da Contabilidade. 5.ed. São Paulo: Atlas, 1999. 


\subsubsection{Conceitos contábeis básicos}

Os princípios contábeis norte-americanos (US GAAP), assim como as normas brasileiras de contabilidade, adotam os seguintes conceitos básicos de contabilidade para a apresentação de demonstrações contábeis:

- Custo histórico - os itens do patrimônio são registrados pelo seu valor original, pago ou atribuído na data de ocorrência da transação;

- Regime de competência de exercícios - o efeito das transações é atribuído ao resultado do período em que ocorrerem;

- Continuidade das operações da empresa - presume-se que a entidade continuará a operar em suas atividades indefinidamente;

- Consistência e comparabilidade - as práticas e procedimentos contábeis adotados pela entidade devem ser consistentes, a fim de permitir a comparabilidade de suas demonstrações contábeis entre exercícios e com outras entidades.

\subsubsection{Demonstrações contábeis}

Nos Estados Unidos as demonstrações contábeis requeridas são as seguintes:

- Balanço Patrimonial;

- Demonstração do Resultado;

- Demonstração dos Lucros Acumulados;

- Demonstração dos Fluxos de Caixa; 
- Demonstração das Mutações do Patrimônio Líquido;

- Notas Explicativas.

A apresentação de demonstrações contábeis comparativas é obrigatória para companhias de capital aberto registradas na SEC (Securities and Exchange Commission), sendo um mínimo de dois anos para o Balanço Patrimonial e três anos para as Demonstrações do Resultado, Lucros Acumulados e Fluxo de Caixa.

A Demonstração das Mutações no Patrimônio Líquido apresenta as mudanças nos componentes do patrimônio líquido. Essas informações podem ser divulgadas, alternativamente, nas Notas Explicativas.

As Notas Explicativas são parte integrante das demonstrações contábeis. Práticas contábeis incomuns, inovadoras ou específicas do ramo de negócios devem ser divulgadas.

A Demonstração dos Fluxos de Caixa fornece informações sobre entradas e saídas de dinheiro durante o período e é classificada em atividades operacionais, de financiamento e de investimento.

No Brasil são requeridas as seguintes demonstrações contábeis:

- Balanço Patrimonial;

- Demonstração do Resultado;

- Demonstração das Origens e Aplicações de Recursos; 
- Demonstração dos Lucros ou Prejuízos Acumulados, que normalmente é substituída pela demonstração das Mutações do Patrimônio Líquido;

- Notas Explicativas.

As demonstrações contábeis no Brasil também devem ser comparativas e existem divulgações mínimas que devem constar das Notas Explicativas. A maior diferença é que, ao invés da Demonstração dos Fluxos de Caixa, aqui é requerida a Demonstração das Origens e Aplicações de Recursos, a qual é obrigatória para empresas com certo valor de patrimônio líquido, mas normalmente é apresentada independentemente do limite.

\subsubsection{Mudança de critérios contábeis}

Nos EUA, assim como no Brasil, mudanças de aplicação de critérios contábeis serão aceitas somente se constituírem uma evolução técnica que aprimore a apresentação das demonstrações contábeis.

Essas mudanças podem ser obrigatórias, quando provenientes de normas expedidas por órgãos reguladores, ou arbitrárias, quando se tratarem de mudanças nas estimativas ou na entidade.

Nos EUA as normas que tratam de mudanças contábeis obrigatórias orientam também sobre a data de aplicabilidade, o método de utilização e as divulgações requeridas. No Brasil as normas são normalmente aplicadas a partir do exercício em que são publicadas. 
Mudanças de critérios contábeis arbitrárias nas companhias de capital aberto norte-americanas requerem uma carta do auditor independente com comentários sobre a mudança para fins de arquivamento na SEC.

Os efeitos das mudanças contábeis nos EUA são reconhecidos no resultado do exercício em que ocorrer a respectiva mudança, enquanto que no Brasil esses efeitos são reconhecidos como ajuste de exercícios anteriores. Em ambos os países é obrigatória a mensuração e divulgação desses efeitos, bem como das razões que levaram à mudança dos critérios.

\subsubsection{Ajustes de exercícios anteriores}

Nos EUA a maioria dos ajustes nas demonstrações contábeis é reconhecida no resultado do exercício. Os ajustes de exercícios anteriores, que são lançados fora do resultado do exercício, restringem-se a certas mudanças de critérios contábeis e à correção de erros, devendo ser refeitas as demonstrações anteriormente apresentadas, diferentemente do Brasil onde tais ajustes são apresentados em uma linha em separado na Demonstração das Mutações do Patrimônio Líquido do período em que forem efetuados.

A norma norte-americana exige que seja divulgada, para todos os exercícios apresentados, a natureza dos ajustes em demonstrações contábeis previamente emitidas, bem como os efeitos de sua correção no resultado antes 
dos itens extraordinários, resultado líquido do exercício corrente e os respectivos valores por ação, bruto e líquido do imposto de renda aplicável.

No Brasil é mais comum o registro dos ajustes em exercícios anteriores fora do resultado do período, sendo lançados diretamente contra lucros ou prejuízos acumulados. Serão admitidos os seguintes ajustes, conforme o $\S 1^{\circ}$ do art. 186, da Lei ํㅜ 6.404/76:

"Como ajustes de exercícios anteriores serão considerados apenas os decorrentes de efeitos da mudança de critério contábil, ou da retificação de erro imputável a determinado exercício anterior, e que não possam ser atribuídos a fatos subseqüentes".

Embora o uso da palavra "apenas" dê idéia de restrição ao uso dos ajustes, no Brasil se tem mais liberdade para efetuar ajustes de exercícios anteriores do que nos EUA, onde a utilização desses ajustes é bem mais restrita.

\subsubsection{Itens Extraordinários}

Itens extraordinários são eventos geradores de receita ou despesa, que são alheios à atividade normal da empresa e cuja ocorrência é irregular ou esporádica. De acordo com as normas norte-americanas, uma transação é qualificada como item extraordinário quando não ocorre com freqüência e sua natureza é não habitual como, por exemplo, a expropriação de ativos e os desastres da natureza. 
Nos EUA esses itens devem ser registrados no resultado do período de competência e divulgados separadamente na Demonstração do Resultado.

No Brasil o conceito de itens extraordinários é similar ao dos EUA, no entanto, na prática, as empresas apresentam tais itens na Demonstração do Resultado como não-operacionais.

\subsubsection{Eventos subseqüentes}

Eventos subseqüentes são fatos que podem ocorrer após a data de encerramento das demonstrações contábeis de uma entidade, mas antes de sua emissão e, por isso, não se configuram ajustes de exercícios anteriores.

O tratamento contábil dado a esses eventos não apresenta diferenças entre as práticas contábeis norte-americanas e brasileiras, pois nos dois países os eventos subseqüentes podem ser classificados em duas modalidades para efeito de tratamento contábil: eventos subseqüentes do tipo 1 e eventos subseqüentes do tipo 2, a seguir comentados:

\subsubsection{Eventos subseqüentes do tipo 1}

São eventos que fornecem evidências adicionais de condições já existentes na data do balanço e que afetam as estimativas sobre as quais foram preparadas as demonstrações contábeis como, por exemplo, perdas de crédito resultantes da deterioração da situação financeira do cliente, já existente na 
data do balanço, mas somente então evidente. Outro exemplo é a liquidação de um passivo que havia sido estimado em um valor diferente.

Esses eventos devem ser considerados na preparação das demonstrações contábeis e quaisquer mudanças nas estimativas resultantes dos mesmos devem ser ajustadas nas demonstrações que estão sendo elaboradas.

\subsubsection{Eventos subseqüentes do tipo 2}

Esses eventos fornecem evidências de condições não existentes na data do balanço, mas que surgiram após aquela data. Exemplos destas situações são:

a) aporte de novos recursos, inclusive como aumento de capital;

b) compra de nova subsidiária ou de participação adicional relevante em investimento anterior;

c) destruição de estoques ou de instalações em decorrência de sinistro (catástrofes); e

d) alteração do controle societário.

Esses eventos não resultam em ajuste das demonstrações contábeis que estão sendo elaboradas, devendo apenas ser citados em notas explicativas. 


\subsubsection{Contingências}

As perdas contingentes também recebem o mesmo tratamento contábil no Brasil e nos EUA, o qual varia conforme a categoria da perda esperada, de acordo com a seguinte classificação:

a) perda provável - deve ser constituída provisão contábil pelo valor estimado da perda, com margem de erro para baixo e para cima, contabilizando-se pelo valor mínimo, com divulgação em notas explicativas das demonstrações contábeis;

b) perda possível - exige-se apenas a divulgação em notas explicativas, informando o valor estimado, a natureza e a situação da contingência;

c) perda remota - não é necessária nenhuma divulgação em notas explicativas nem tampouco a constituição de qualquer provisão.

\subsubsection{Clientes, Fornecedores e Financiamentos}

As normas norte-americanas (APB 21) requerem o ajuste a valor presente para contas a receber e a pagar a longo prazo, em cujos montantes não esteja embutida nenhuma indexação ou taxa de juros ou, ainda, nos casos em que a taxa de juros cobrada for anormal em relação às taxas de juros praticadas no mercado nas datas de emissão dos títulos. Com relação aos direitos e obrigações de curto prazo é facultativa a aplicação de ajuste a valor presente. 
No Brasil, até 1995, o ajuste a valor presente era requerido para fins de correção monetária integral das demonstrações contábeis, conforme determinação da CVM (Comissão de Valores Mobiliários), independentemente do prazo para pagamento ou recebimento e com base na taxa da ANBID (Associação Nacional dos Bancos de Investimento), no entanto, para fins de legislação societária nenhum ajuste era requerido para essas contas. Atualmente o uso da correção monetária integral é facultativo, de acordo com a Instrução CVM 248 de 29.03.96.

Nos EUA as despesas de juros de financiamentos para aquisição ou construção de bens são capitalizadas no ativo imobilizado, somados aos bens a que se referirem e amortizados durante suas vidas úteis (SFAS no 34 ).

No Brasil, os procedimentos diferem conforme a categoria de bens, de acordo com o Manual de Contabilidade das Sociedades por Ações ${ }^{28}$ :

a) bens comprados de terceiros:

"Os encargos financeiros decorrentes de empréstimos e financiamentos para aquisição de bens do ativo imobilizado não devem ser incluídos no custo dos bens adquiridos, mas lançados como despesas financeiras (ou ativo diferido, se em fase de construção)."

b) bens construídos, que atendem ao disposto nos itens I e II da Deliberação CVM no 193/96, conforme a seguir:

"I - Os juros incorridos e demais encargos financeiros, relativamente a financiamentos obtidos de terceiros, para construção de bens integrantes do ativo imobilizado (...), devem ser registrados em conta destacada, que evidencie a sua natureza, e classificados no mesmo grupo do ativo que lhe deu origem.

${ }^{28}$ IUDíCIBUS, Sérgio de. MARTINS, Eliseu. GELBECK, Ernesto Rubens. Manual de Contabilidade das Sociedades por Ações. 5a ed. rev. e atual. São Paulo: Atlas, 2000, p.189. 
II - A alocação desses juros e encargos ao resultado do exercício deverá ser feita em consonância com os prazos de depreciação, amortização, exaustão ou baixa dos ativos financiados."

\subsubsection{Avaliação de estoques}

Nos EUA, assim como no Brasil, os estoques são avaliados pelo custo de aquisição e produção ou pelo seu valor de realização (mercado), o que for menor. Os principais sistemas de avaliação de estoques admitidos nos EUA são: FIFO (first in first out), que equivale ao PEPS (Primeiro que Entra, Primeiro que Sai); LIFO (last in first out), que equivale ao UEPS (Último que Entra, Primeiro que Sai) e o custo médio, que representa a média ponderada móvel dos vários custos de aquisição. Todos esses métodos são aceitos nos EUA para fins fiscais.

No Brasil podem ser usados os métodos PEPS, UEPS, custo médio, preço específico, que representa quanto custou cada item individualmente, e o preço de venda a varejo, onde o custo é calculado com base em um percentual sobre o preço de venda. Não é admitido pela legislação fiscal o uso do sistema UEPS (LIFO). 


\subsubsection{Investimentos em outras empresas}

Nos EUA, como no Brasil, os investimentos podem ser avaliados pelo método de custo ou pelo método de equivalência patrimonial, de acordo com os limites e a influência da participação societária.

Em algumas situações, será ainda exigida a consolidação das demonstrações contábeis, que consiste na apresentação dos resultados das operações e da posição financeira da sociedade controladora e de suas controladas, excluídas as transações entre essas companhias, como se o grupo fosse uma única empresa que tivesse uma ou mais filiais ou divisões.

O método de equivalência patrimonial é utilizado nos EUA para avaliar investimentos em joint ventures (empresas sob controle conjunto) e em empresas nas quais um investidor detenha de $20 \%$ até $50 \%$ da participação (acima de $50 \%$ é exigida a consolidação) e possa exercer influência significativa em sua administração. Investimentos (diretos ou indiretos) a partir de $20 \%$ das ações com direito a voto de uma empresa pressupõem a existência de tal influência.

No Brasil são avaliados pelo método de equivalência patrimonial os investimentos em sociedades controladas, bem como os investimentos considerados relevantes em coligadas, o que significa uma participação que tenha influência na administração ou que seja de no mínimo $20 \%$ do capital social. Tais disposições foram estendidas às sociedades "equiparadas a coligadas", através da Instrução CVM n 247/96. 
Para efeito da legislação brasileira, são definidas como coligadas as sociedades em que uma participa com $10 \%$ ou mais do capital total da outra, sem controlá-la; é controlada a sociedade cuja investidora é titular de direitos de sócio que the assegurem, de modo permanente, preponderância nas deliberações sociais e tenha poder de eleger a maioria dos administradores da investida.

Segundo o Manual de Contabilidade das Sociedades por Ações ${ }^{29}$, "equipara-se à coligada a sociedade que participa, direta ou indiretamente com $10 \%$ ou mais do capital votante da investida, sem controlá-la, independentemente da participação no capital total da investida".

Nos EUA a consolidação das demonstrações contábeis é requerida quando a empresa investidora detiver mais de $50 \%$ das ações com direito a voto da investida (controlada), no entanto, mesmo atendendo a esses requisitos, a não-consolidação é permitida nos casos de empresas cujas atividades não sejam semelhantes ou homogêneas ou, ainda, quando o controle seja somente temporário ou restrito (SFAS ํำ 94).

A consolidação é exigida para as companhias abertas brasileiras com mais de $30 \%$ do seu patrimônio líquido representado por investimentos em sociedades controladas, cuja divulgação deve ser feita juntamente com as demonstrações contábeis individuais de cada empresa (art. 249 da Lei no 6.404/76). Entretanto, igualmente aos EUA, é permitida a não-consolidação

\footnotetext{
${ }^{29}$ IUDÍCIBUS, Sérgio de. MARTINS, Eliseu. GELBECK, Ernesto Rubens. Manual de Contabilidade das Sociedades por Ações. 5a ed. rev. e atual. São Paulo: Atlas, 2000, p.142.
} 
para empresas com atividades não semelhantes e para a situação de sócio majoritário temporário, ou outras situações que venham a ser autorizadas pela CVM.

Outra diferença observada entre as práticas norte-americanas e as brasileiras é a determinação do goodwill sobre aquisição de investimentos.

Conforme ludícibus e Marion" goodwill é "o excesso de preço pago pela compra de um empreendimento ou patrimônio sobre o valor de mercado de seus ativos líquidos”.

Para fins de US GAAP o goodwill é determinado pela diferença entre o preço de compra e o valor justo do patrimônio líquido da investida, ou seja, os ativos e passivos são avaliados ao "valor justo" (fair value), enquanto que no Brasil ao invés do goodwill, apura-se o ágio na aquisição do investimento, que representa a diferença entre o valor pago e o valor contábil do patrimônio líquido da investida, sem que sejam mensurados os valores de mercado dos ativos e passivos.

goodwill deve ser amortizado à medida em que os resultados futuros esperados que Ihe deram origem sejam auferidos, sendo que nos EUA o prazo máximo de amortização é de 40 anos, enquanto que no Brasil o prazo máximo é de 10 anos.

\footnotetext{
${ }^{30}$ IUDÍCIBUS, Sérgio de; MARION, José Carlos. Dicionário de Termos de Contabilidade. São Paulo: Atlas: 2001, p.102.
} 


\subsubsection{Depreciação}

Nos EUA a depreciação dos bens registrados no ativo imobilizado é calculada com base na vida útil estimada do bem. São admitidos os seguintes métodos de depreciação:

a) depreciação linear;

b) saldos decrescentes (declining balance);

c) soma de dígitos;

d) unidades de produção; ou

e) horas de uso.

No Brasil as normas societárias sobre depreciação são, teoricamente, iguais às norte-americanas, no entanto, na prática, são seguidas as instruções da legislação fiscal, que considera aceitável somente o método de depreciação linear e publica periodicamente os prazos de vida útil admitidos para cada espécie de bem. O contribuinte, no entanto, tem o direito de calcular quotas de depreciação adequadas às condições de uso de seus bens, diferentes das estabelecidas pela legislação fiscal, desde que consiga provar essa adequação.

\subsubsection{Reavaliação}

Nos EUA as reavaliações de ativos são admitidas somente para os casos de aquisições de empresas, em que os bens são reavaliados para fins de 
negociação, bem como para determinação do goodwill sobre a aquisição do investimento.

No Brasil é permitida a contabilização de reavaliação de bens, a qual deve se basear em laudo técnico assinado por três peritos ou por empresa especializada e cumprir todos os requisitos do art. $8^{\circ}$ da Lei $n^{\circ}$ 6.404/76, devendo, ainda, ser aprovada pela assembléia de acionistas.

\subsubsection{Ativo diferido}

Nos EUA, diferentemente do Brasil, as despesas pré-operacionais e os gastos com pesquisa e desenvolvimento de novos produtos são, geralmente, reconhecidos como despesas do período em que forem incorridos. Entretanto, podem ser diferidos os gastos com pesquisa e desenvolvimento relacionados às atividades conduzidas por terceiros e os exclusivos das indústrias extrativas, bem como os custos de produção adicionais em empresas ou segmentos em estágio inicial de produção (start-up costs), desde que haja uma avaliação positiva da recuperação futura desses custos.

No Brasil é permitido o diferimento dos referidos gastos, de acordo com o art. 179 da Lei ํo 6.404/76, que estabelece:

"No ativo diferido são classificadas as aplicações de recursos em despesas que contribuirão para a formação do resultado de mais de um exercício social, inclusive os juros pagos ou creditados aos acionistas durante o período que anteceder o início das operações sociais". 
Os gastos relacionados com reorganização ou reestruturação da empresa devem ser contabilizados como despesa operacional do exercício em que forem incorridos. No entanto, o Banco Central do Brasil facultou às instituições financeiras o diferimento desses gastos, através das Circulares ํํs. $2.582 / 95$ e $2.707 / 96$.

Foi também facultado às companhias abertas brasileiras o diferimento da variação cambial líquida negativa, acima de determinado limite, em 1999 e 2001, de acordo com as Deliberações CVM n² 294, de 26.03.1999 e n 404, de 27.09.2001, respectivamente, o que motivou a emissão pelo Ibracon de um pronunciamento contrário a essa posição.

\subsubsection{Imposto de renda diferido}

Nos EUA e no Brasil constitui-se provisão para imposto de renda diferido sobre as diferenças temporárias existentes entre a base fiscal e os saldos constantes do balanço apresentado de acordo com as normas societárias, incluídos os créditos e prejuízos fiscais.

A principal diferença entre as práticas dos dois países na apuração do saldo do imposto de renda diferido ativo é que no Brasil se deve possuir alto grau de certeza de que os lucros reais futuros permitirão sua realização, enquanto que nos EUA exige-se uma margem de segurança superior a $50 \%$ (SFAS 109) e, caso não exista essa segurança, deve ser constituída uma provisão para redução do valor do ativo. 


\subsubsection{Plano de benefícios pós-emprego}

Nos EUA o tratamento contábil a ser dado pelas empresas patrocinadoras aos planos de benefícios pós-emprego a empregados, também conhecidos como fundos de pensão, depende de sua responsabilidade em relação ao fundo, que pode ser de dois tipos: plano de benefícios definidos ou plano de contribuições definidas, os quais possuem as seguintes características:

a) Plano de benefícios definidos:

- garante o valor do benefício estipulado no plano independente da performance obtida na aplicação do patrimônio do fundo de pensão;

- o percentual da contribuição sobre os salários não é definido, podendo ser alterado ao longo do tempo;

- a patrocinadora assume todos os riscos para garantir o benefício previamente definido.

b) Plano de contribuições definidas:

- o valor do benefício depende da performance obtida na aplicação do patrimônio do fundo de pensão;

- o percentual da contribuição sobre os salários é definido previamente;

- a responsabilidade da patrocinadora limita-se ao pagamento da contribuição previamente definida. 
Nos casos de fundos de pensão com benefícios definidos, a empresa patrocinadora deve contabilizar, como ativo ou passivo, a diferença entre o custo de pensão aprovisionado e o montante realmente aplicado como contribuição ao plano. Deve, ainda, ser reconhecida uma obrigação de pensão mínima quando a obrigação de benefícios acumulados for superior ao valor de mercado dos ativos do plano, ajustado pelos montantes pagos antecipadamente ou aprovisionados (SFAS no 87).

Quando se tratar de plano de contribuições definidas, a obrigação da patrocinadora limita-se ao custo mensal da contribuição, proporcional aos salários de seus empregados, o qual deve ser contabilizado pelo regime de competência.

No Brasil, até o exercício de 2000, o procedimento contábil adotado pela patrocinadora para qualquer dos tipos de fundos de pensão, era o de que as despesas com contribuições para o plano fossem reconhecidas como despesa do período em que fossem transferidas ao fundo, sem que nenhuma provisão fosse constituída contabilmente para reconhecer, durante o período de atividade do empregado, as despesas com as contribuições futuras a que fará jus após a sua aposentadoria.

Em 13 de dezembro de 2000 a Comissão de Valores Mobiliários - CVM emitiu a Deliberação no 371, que estabelece a adoção, por todas as companhias abertas, dos requerimentos apresentados no pronunciamento elaborado pelo Instituto dos Auditores Independentes do Brasil (Ibracon), no que se refere à avaliação e registro contábil dos valores decorrentes de 
benefícios a empregados, tendo como data base 31 de dezembro de 2001 . Referido pronunciamento não apresenta diferenças significativas em relação à norma norte-americana.

Em ambos os países são exigidas divulgações específicas em notas explicativas sobre os planos de benefícios a empregados.

\subsubsection{Leasing}

As operações de leasing, denominadas no Brasil como Arrendamento Mercantil, classificam-se em leasing operacional e leasing financeiro, de acordo com as seguintes características:

a) leasing operacional

- os contratos geralmente são de curta duração e canceláveis a qualquer tempo;

- os custos de manutenção, impostos, seguros e assistência técnica geralmente são de responsabilidade da arrendadora.

b) leasing financeiro

- o prazo dos contratos geralmente é igual ou superior a $75 \%$ da vida útil do bem arrendado;

- é transferido à arrendatária a responsabilidade pelos custos e riscos decorrentes do uso do bem;

- a propriedade do bem geralmente é transferida para a arrendatária ao final do contrato. 
O tratamento contábil dado às operações de leasing operacional é o mesmo no Brasil e nos EUA, que consiste em:

a) na arrendadora - o bem é registrado no seu ativo e as contraprestações são reconhecidas como receitas de aluguéis do período em que são auferidas;

b) na arrendatária - não registra o bem no seu ativo $e$ as contraprestações são contabilizadas como despesas de aluguéis do período em que são incorridas.

As operações de leasing financeiro, nos EUA, são contabilizadas como uma operação de financiamento de bens de uso, ou seja, o bem é registrado no ativo imobilizado, pelo valor total da operação, e tem como contrapartida uma obrigação contabilizada no passivo circulante e exigível a longo prazo, conforme os prazos de vencimento das contraprestações. Este procedimento não segue a forma, mas a essência da transação que, de fato, se caracteriza como uma operação de financiamento.

No Brasil, para fins de contabilização, prevalece a forma sobre a essência dessas operações, denominadas de Arrendamento Mercantil. Assim, o leasing financeiro recebe o seguinte tratamento contábil no Brasil:

- As contraprestações são registradas como despesa operacional do período de vigência do contrato e o passivo não é reconhecido pelo valor total contratado, mas pelos valores mensais das contraprestações; 
- No ativo imobilizado é registrado somente o valor residual garantido no contrato da operação, que representa o valor pelo qual o bem será adquirido ao final do contrato, quando da opção de compra pelo arrendatário. Muitas vezes, o valor residual não é ativado sob a alegação de que não é relevante. 


\section{CAPÍTULO 3}

\section{Histórico da Inflação no Brasil}

A inflação é a contínua alta no nível de preços dos diversos bens e serviços de um país, que corrói o poder aquisitivo da moeda. As causas da inflação podem ser de custo ou de demanda. O Dicionário de Termos de Contabilidade $^{31}$ define cada uma dessas modalidades de inflação da seguinte forma:

"Inflação de custo. Denominação dada ao processo inflacionário desencadeado pela prática das grandes empresas de defender as margens de lucro repassando para os preços as elevações de seus custos unitários de produção. Tal modalidade de inflação pressupõe duas coisas: (a) crescimento do custo de produção acima do ritmo da inflação e dos ganhos de produtividade; e (b) estruturas concentradas de mercado em que os preços não são determinados pelo livre jogo de demanda e de oferta, mas fixados unilateralmente pelas empresas."

"Inflação de demanda. Consiste no processo de elevação do nível geral de preços que decorre da existência de uma demanda que não pode ser atendida pela disponibilidade interna de bens e serviços."

A inflação tem estado presente por um longo tempo na história do Brasil. Vários planos de estabilização econômica foram implantados pelo governo com o objetivo de eliminá-la. A tabela a seguir apresenta as várias transformações por que passou a moeda brasileira no período de 1942 a 1994.

${ }^{31}$ IUDÍCIBUS, Sérgio de; MARION, José Carlos. Dicionário de Termos de Contabilidade. São Paulo: Atlas: 2001, p.110. 


\begin{tabular}{|c|c|c|c|c|c|}
\hline Denominação & Símbolo & $\begin{array}{l}\text { Período de } \\
\text { vigência }\end{array}$ & $\begin{array}{l}\text { Paridade em } \\
\text { relação à moeda } \\
\text { anterior }\end{array}$ & $\begin{array}{l}\text { Extinção } \\
\text { de } \\
\text { centavos }\end{array}$ & $\begin{array}{l}\text { Fundamento } \\
\text { legal }\end{array}$ \\
\hline Cruzeiro & $\mathrm{Cr} \$$ & $\begin{array}{c}01.11 .1942 a \\
12.02 .1967\end{array}$ & $\begin{array}{l}1.000 \text { réis }=1,00 \\
\text { cruzeiro (1 conto } \\
\text { de réis }=1.000 \\
\text { cruzeiros) }\end{array}$ & \begin{tabular}{|l|} 
A fração do \\
cruzeiro \\
denominada \\
"centavo" foi \\
extinta a \\
partir de \\
01.12 .1964
\end{tabular} & $\begin{array}{l}\text { Decreto-lei } n^{\circ} \\
\text { 4.791, de } \\
\text { 05.10.42; Lei } n^{\circ} \\
\text { 4.511, de } \\
01.12 .1964 .\end{array}$ \\
\hline Cruzeiro Novo & NCr\$ & $\begin{array}{c}13.02 .1967 a \\
14.05 .1970\end{array}$ & $\begin{array}{l}1.000 \text { cruzeiros }= \\
1,00 \text { cruzeiro novo }\end{array}$ & & $\begin{array}{l}\text { Decreto-lei } n^{0} 1 \\
\text { de 13.11.1965; } \\
\text { Resolução do } \\
\text { Banco Central } n^{\circ} \\
47, \text { de } \\
\text { 13.02.1967 }\end{array}$ \\
\hline Cruzeiro & $\mathrm{Cr} \$$ & $\begin{array}{c}15.05 .1970 a \\
27.02 .1986\end{array}$ & $\begin{array}{l}1,00 \text { cruzeiro novo } \\
=1,00 \text { cruzeiro }\end{array}$ & \begin{tabular}{|l|} 
A fração do \\
cruzeiro \\
denominada \\
"centavo" foi \\
extinta a \\
partir de \\
16.08 .1984
\end{tabular} & $\begin{array}{l}\text { Resolução do } \\
\text { Banco Central }{ }^{\circ} \\
\text { 144, de } \\
\text { 31.03.1970; Lei } \\
n^{\circ} 7.214 \text {, de } \\
\text { 15.08.1984 }\end{array}$ \\
\hline Cruzado & $C z \$$ & $\begin{array}{c}28.02 .1986 a \\
15.01 .1989\end{array}$ & $\begin{array}{l}1.000 \text { cruzeiros }= \\
1,00 \text { cruzado }\end{array}$ & & $\begin{array}{l}\text { Decreto-lei } n^{0} \\
2.283, \text { de } \\
27.02 .1986\end{array}$ \\
\hline Cruzado Novo & $N C z \$$ & $\begin{array}{c}16.01 .1989 a \\
15.03 .1990\end{array}$ & $\begin{array}{l}1.000 \text { cruzados }= \\
1,00 \text { cruzado novo }\end{array}$ & & $\begin{array}{l}\text { Medida } \\
\text { Provisória } n^{\circ} 32, \\
\text { de 15.01.1989, } \\
\text { convertida na Lei } \\
n^{\circ} 7.730 \text {, de } \\
31.01 .1989\end{array}$ \\
\hline Cruzeiro & $\mathrm{Cr} \$$ & $\begin{array}{c}16.03 .1990 a \\
31.07 .1993\end{array}$ & $\begin{array}{l}1,00 \text { cruzado novo } \\
=1,00 \text { cruzeiro }\end{array}$ & & $\begin{array}{l}\text { Medida } \\
\text { Provisória } n^{\circ} \\
\text { 168, de } \\
\text { 15.03.1990, } \\
\text { convertida na Lei } \\
n^{\circ} 8.024 \text {, de } \\
12.04 .1990\end{array}$ \\
\hline Cruzeiro Real & $C R \$$ & $\begin{array}{c}01.08 .1993 a \\
30.06 .1994\end{array}$ & $\begin{array}{l}1.000 \text { cruzeiros }= \\
1,00 \text { cruzeiro real }\end{array}$ & & $\begin{array}{l}\text { Medida } \\
\text { Provisória } n^{\circ} 336 \\
\text { de 28.07.1993, } \\
\text { convertida na Lei } \\
n^{\circ} \text { 8.697, de } \\
27.08 .1993 \text { e } \\
\text { Resolução } \\
\text { BACEN } n^{\circ} 2.010 \text {, } \\
\text { de 28.07.1993 }\end{array}$ \\
\hline Real & $R \$$ & $\begin{array}{c}\text { Desde } \\
01.07 .1994\end{array}$ & \begin{tabular}{|l|}
2.750 cruzeiros \\
reais $=1,00$ real
\end{tabular} & & $\begin{array}{l}\text { Leis } n^{\circ} \text { s } 8.880 \text { de } \\
27.05 .1994 \text { e } \\
9.069 \text { de } \\
29.06 .1995\end{array}$ \\
\hline
\end{tabular}

Fonte: IOB - Calendário Objetivo de Obrigações e Tabelas Práticas - Setembro/1998 
O convívio com a inflação por um período tão longo e com taxas tão exorbitantes, fez com que se desenvolvessem no Brasil estudos dos efeitos inflacionários e métodos de mensuração desses efeitos nas demonstrações contábeis das empresas, no sentido de salvaguardar a informação contábil da deterioração da moeda, que é a unidade de medida utilizada na Contabilidade.

Assim surgiu o processo denominado de correção monetária das demonstrações contábeis, o qual é definido de três formas pelo Dicionário de Termos de Contabilidade ${ }^{32}$, conforme a seguir:

"(1) Processo pelo qual valores históricos são reconstruídos (restaurados, atualizados) em históricos-corrigidos, trazendo-os em moeda corrente em certa data, conforme flutuação de preços da economia; (2) Correção de demonstrativos pelas variações do poder aquisitivo médio geral da moeda (medido por um índice geral de preços ou por um índice de flutuações do poder aquisitivo da moeda para a entidade em si, dentro de sua escala de oferta e procura de bens e serviços; (3) Correção dos demonstrativos contábeis aos custos de reposição específicos de ativos e passivos (e conseqüentemente de receitas e despesas), segundo várias fórmulas possíveis."

A correção monetária foi introduzida nas demonstrações contábeis brasileiras, de forma facultativa, a partir de 1944, por regulamentação do Decreto-lei $n^{0} 5.844 / 43$, passando a ser obrigatória a partir de 1964, através da Lei $n^{0} 4.357 / 64$.

O quadro a seguir, apresentado por Heraldo Gilberto de Oliveira ${ }^{33}$ em sua dissertação de mestrado, faz uma retrospectiva dos diversos normativos que regulamentaram a correção monetária no Brasil:

\footnotetext{
${ }^{32}$ IUDíCIBUS, Sérgio de; MARION, José Carlos. Dicionário de Termos de Contabilidade. São Paulo: Atlas: 2001, p.49
} 


\begin{tabular}{|c|c|}
\hline Ano & REGULAMENTAÇÃO \\
\hline 1944 & $\begin{array}{l}\text { O Decreto-lei } n^{\circ} 5.844 / 43 \text { passou a permitir, a partir de } 1^{\circ} \text { de janeiro de } \\
1944, \text { a atualização do ativo imobilizado, em caráter excepcional; o } \\
\text { resultado da atualização estava sujeito à tributação pelas alíquotas } \\
\text { normais. }\end{array}$ \\
\hline 1951 & $\begin{array}{l}\text { A Lei } n^{\circ} 1.474 / 51 \text { permitiu a reavaliação do ativo imobilizado adquirido } \\
\text { até } 31 \text { de dezembro de } 1946 \text {, dando como benefício a tributação do seu } \\
\text { acréscimo à alíquota reduzida de } 10 \% \text {; o aumento de capital decorrente } \\
\text { da reavaliação poderia ser feito até } 31 \text { de dezembro de } 1952 \text {. }\end{array}$ \\
\hline 1952 & $\begin{array}{l}\text { A Lei } n^{\circ} 1.772 / 52 \text { vem prorrogar o prazo concedido pela Lei } n^{\circ} 1.474 / 51 \\
\text { de } 31 \text { de dezembro de } 1952 \text { para } 30 \text { de junho de } 1953 \text {. }\end{array}$ \\
\hline 1956 & $\begin{array}{l}\text { De } 30 \text { de junho de } 1953 \text { até } 4 \text { de setembro de } 1956 \text {, o benefício esteve } \\
\text { extinto. Desta data até } 31 \text { de outubro do próprio ano de } 1956 \text {, com o } \\
\text { advento da Lei } n^{\circ} 2.862 / 56 \text {, a reavaliação do ativo imobilizado foi } \\
\text { novamente permitida com alíquota excepcional; a partir desta data } \\
\text { estes acréscimos passaram a sofrer tributação à alíquota normal. }\end{array}$ \\
\hline 1958 & $\begin{array}{l}\text { A partir deste ponto a correção monetária ganha o caráter permanente. } \\
\text { A Lei } n^{\circ} 3.470 / 58 \text { facultava a adoção da correção monetária, que, no } \\
\text { entanto, poderia ser realizada a qualquer tempo, e sobre o seu } \\
\text { montante incidia imposto à alíquota de } 10 \% \text {. A depreciação somente } \\
\text { seria reconhecida sobre o valor do custo histórico. }\end{array}$ \\
\hline 1964 & $\begin{array}{l}\text { A contabilização da correção monetária, anteriormente facultativa, } \\
\text { passa a ser obrigatória, através da Lei } n^{\circ} 4.357 / 64 \text {; a taxação da } \\
\text { correção, que passou a ser } 5 \% \text { foi extinta a partir de } 1^{\circ} \text { de janeiro de } \\
\text { 1967. A depreciação do custo corrigido monetariamente passa a ser } \\
\text { aceita. }\end{array}$ \\
\hline 1965 & $\begin{array}{l}\text { Com a Lei } n^{\circ} 4.728 / 65 \text {, o resultado da correção monetária do ativo } \\
\text { imobilizado poderia ser registrado como reserva no patrimônio líquido, } \\
\text { sem a necessidade de produzir um aumento de capital. A correção }\end{array}$ \\
\hline
\end{tabular}

${ }^{33}$ OLIVEIRA, Heraldo Gilberto de. A Extinção da Correção Monetária no Brasil - Principais Implicações Contábeis e Tributárias. Dissertação de Mestrado apresentada à Faculdade de Economia, Administração e Contabilidade da Universidade de São Paulo, 1997, pp.18 a 24. 


\begin{tabular}{|c|c|}
\hline Ano & REGULAMENTAÇÃO \\
\hline & $\begin{array}{l}\text { monetária sobre o capital de giro próprio passa a ser aceita como } \\
\text { dedutível no cálculo do lucro extraordinário. Com a Lei } n^{\circ} 4.862 / 65 \text {, a } \\
\text { dedução da correção monetária sobre o capital de giro próprio passa a } \\
\text { ser aceita no cálculo do imposto de renda normal. }\end{array}$ \\
\hline 1966 & $\begin{array}{l}\text { Através de Decreto-lei } n^{\circ} 62 \text { o sistema de indexação passaria a ser } \\
\text { mais completo, abrangendo tanto as contas ativas como as passivas. O } \\
\text { resultado da correção monetária não seria tributado. Este decreto } \\
\text { estabeleceu normas para o cálculo da correção e outras com efeito } \\
\text { contábil. (...) }\end{array}$ \\
\hline 1974 & $\begin{array}{l}\text { A sistemática de correção monetária, com aprimoramentos introduzidos } \\
\text { pelo Decreto-lei } n^{\circ} 1.302 / 73 \text {, é complementada pelo Decreto-lei } n^{\circ} \\
1.338 / 74 ; \text { regulamentada a insuficiência de depreciação, acabando com } \\
\text { os ativos imobilizados com o valor residual após esgotada a sua vida } \\
\text { útil e regulamentando o reconhecimento do cálculo da reserva de } \\
\text { capital de giro próprio negativo, antes desconsiderado pela tributação. }\end{array}$ \\
\hline $\begin{array}{c}\text { Lei } n^{\circ} \\
6.404 / 76\end{array}$ & $\begin{array}{l}\text { A Lei das Sociedades por Ações, de } 15 \text { de dezembro de } 1976, \\
\text { determinou o maior avanço no reconhecimento dos efeitos da inflação } \\
\text { sobre as demonstrações contábeis havido até então. De forma } \\
\text { simplificada, a Lei, em seu artigo 185, determina a correção monetária } \\
\text { das contas do ativo permanente e do patrimônio líquido, refletindo, } \\
\text { como contrapartida, no resultado do exercício, na linha de correção } \\
\text { monetária do balanço, os efeitos inflacionários. Dessa forma, o } \\
\text { resultado e o patrimônio líquido passaram a ser adequadamente } \\
\text { apresentados, por refletir a perda de poder aquisitivo da moeda face } \\
\text { aos efeitos da inflação. O imposto de renda, ao ser calculado sobre a } \\
\text { base correta - o lucro apurado adequadamente - representava, de fato, } \\
\text { as alíquotas das legislações vigentes. }\end{array}$ \\
\hline $\begin{array}{c}\text { Decreto } \\
n^{\circ} \\
1.598 / 76\end{array}$ & $\begin{array}{l}\text { A regulamentação fiscal da Lei } n^{\circ} 6.404 / 76 \text { se deu através do Decreto } \\
n^{\circ} 1.598 / 76 \text {. O governo estendeu as normas de correção monetária da } \\
\text { lei societária às demais sociedades. (...) a partir da referida Lei o } \\
\text { imposto de renda das empresas passou a ser pago sobre um resultado } \\
\text { que contemplava os efeitos da inflação, sendo aceito pelas autoridades } \\
\text { fiscais. }\end{array}$ \\
\hline
\end{tabular}




\begin{tabular}{|c|c|}
\hline Ano & REGULAMENTAÇÃO \\
\hline $\begin{array}{l}D L ' s n^{\circ} s . \\
2.287 / 86 \\
2.308 / 86 \\
e \\
2.341 / 87\end{array}$ & $\begin{array}{l}\text { Regulamentam aspectos diversificados acerca da sistemática oficial de } \\
\text { correção monetária de balanços. }\end{array}$ \\
\hline $\begin{array}{c}\text { Instrução } \\
\text { CVM n }{ }^{\circ} \\
64 / 87\end{array}$ & $\begin{array}{l}\text { Outro marco da contabilidade brasileira foi a instrução } 64 \text {, de maio de } \\
1987, \text { da Comissão de Valores Mobiliários, obrigatória para as } \\
\text { sociedades anônimas de capital aberto, e que implantou a técnica } \\
\text { conhecida como "Correção Integral - CMI". A CMI, utilizando os } \\
\text { mesmos índices adotados pela correção monetária societária, } \\
\text { apresentava os balanços e resultados corrigidos para uma única } \\
\text { moeda, do final do período contábil. Os lucros ou prejuízos, que pela } \\
\text { metodologia oficial e na maioria das vezes, tinham a sua expressão } \\
\text { líquida apresentada corretamente, passaram agora a ser demonstrados } \\
\text { na sua formação, ou analiticamente, em moeda de fim de exercício. }\end{array}$ \\
\hline $\begin{array}{l}\text { Leis } n^{\circ} s . \\
7.730 \mathrm{e} \\
7.738 / 89\end{array}$ & $\begin{array}{l}\text { Em 1989, a correção monetária foi, respectivamente extinta e } \\
\text { restabelecida, pelas Leis } 7.730 \text { e } 7738 \text {. Tratou-se de um dos diversos } \\
\text { planos econômicos em que o governo tentou debelar a inflação. Em um } \\
\text { desses planos, no início de } 1989 \text {, conhecido como "Plano Verão", foi } \\
\text { revogado o artigo } 185 \text { da Lei das Sociedades Anônimas. }\end{array}$ \\
\hline $\begin{array}{l}\text { Lei } n^{\circ} \\
7.799 / 89\end{array}$ & $\begin{array}{l}\text { Regulamentou a correção monetária para efeitos fiscais, determinando } \\
\text { as contas a serem corrigidas e procedimentos para a correção e } \\
\text { tributação dos efeitos inflacionários. }\end{array}$ \\
\hline $\begin{array}{l}\text { Lei } n^{\circ} \\
8.200 / 91\end{array}$ & $\begin{array}{l}\text { Em 1990, no bojo do chamado "Plano Collor", o BTNF (Bônus do } \\
\text { Tesouro Nacional Fiscal) foi atualizado por índice significativamente } \\
\text { abaixo da real inflação naquele ano. As demonstrações contábeis das } \\
\text { empresas, no exercício de 1990, apresentaram ativos, patrimônio } \\
\text { líquido e resultados corrigidos abaixo da inflação. A Lei } n^{\circ} 8.200 / 91 \\
\text { determinou que as empresas recalculassem os efeitos da inflação do } \\
\text { exercício 1990, considerando o IPC como indexador, e que a diferença } \\
\text { entre os dois índices fosse contabilizada e os efeitos fiscais } \\
\text { considerados, sendo que o imposto pago a menor fosse recolhido e o } \\
\text { pago a maior compensado. Essa correção complementar pelo IPC } \\
\text { (Índice de Preços ao Consumidor) foi obrigatória. Reconhecendo que } \\
\text { em períodos anteriores também ocorreram subavaliações dos índices } \\
\text { oficiais de correção monetária, a Lei } n^{\circ} 8.200 / 91 \text { facultou o registro da }\end{array}$ \\
\hline
\end{tabular}




\begin{tabular}{|c|c|}
\hline Ano & REGULAMENTAÇÃO \\
\hline & $\begin{array}{l}\text { correção monetária especial sobre o ativo permanente, calculada sobre } \\
\text { índice geral de preços, que fosse creditada a uma reserva no } \\
\text { patrimônio líquido, sem os efeitos fiscais, que somente foram aceitos } \\
\text { sobre a diferença IPC X BTNF. }\end{array}$ \\
\hline $\begin{array}{c}\text { Decreto } \\
n^{\circ} \\
332 / 91 \\
\text { Decreto } \\
n^{\circ} \\
332 / 91\end{array}$ & $\begin{array}{l}\text { O Decreto } n^{\circ} \text { 332/91, alem de regulamentar a Lei } n^{\circ} \text { 8.200/91, } \\
\text { determinou a regulamentação contábil e fiscal básica sobre a correção } \\
\text { monetária até o final do ano de } 1995 \text {. Esse decreto estabelecia a } \\
\text { correção monetária: (a) das contas do ativo permanente; (b) do custo } \\
\text { dos imóveis classificados fora do ativo permanente; (c) das aplicações } \\
\text { em ouro; (d) dos adiantamentos a fornecedores de bens sujeitos à } \\
\text { correção monetária, inclusive quotas de consórcios, exceto se } \\
\text { houvesse previsão de indexação do crédito no período da correção; (e) } \\
\text { dos contratos de mútuo entre pessoas jurídicas ligadas, e com sócios } \\
\text { ou acionistas; (f) dos adiantamentos para aumento de capital; e (g) das } \\
\text { contas do patrimônio líquido, inclusive lucros ou prejuízos cuja } \\
\text { apuração fosse exigida no decorrer do ano calendário. O mesmo } \\
\text { decreto determinou o registro, em conta especial, das contrapartidas } \\
\text { dos ajustes de correção monetária das contas acima descritas, a } \\
\text { dedução, como encargo do período-base, do saldo, se devedor, e o } \\
\text { cômputo no lucro real do saldo credor. }\end{array}$ \\
\hline $\begin{array}{c}\text { Instrução } \\
\text { CVM no } \\
191 / 92\end{array}$ & $\begin{array}{l}\text { A partir da instrução } n^{\circ} 64 / 86 \text { a CVM emitiu uma série de normativos, } \\
\text { aperfeiçoando gradualmente a sistemática de correção integral. Em } \\
1992, \text { com a instrução no } 191 \text {, consolidou as normas e chegou a um } \\
\text { adequado nível de regulamentação de uma tecnologia tão bem } \\
\text { sucedida que acabou por ser considerada por organismos } \\
\text { internacionais de contabilidade como IASC (Intenational Accounting } \\
\text { Standards Committee), hoje IASB (International Accounting } \\
\text { Standards Board), e ISAR (Intragovernamental Working Group of } \\
\text { Experts on International Standards of Accounting and Reporting) da } \\
\text { ONU. }\end{array}$ \\
\hline $\begin{array}{c}\text { Lei } n^{\circ} \\
9.249 / 95\end{array}$ & $\begin{array}{l}\text { A Lei } n^{\circ} \text { 9.249/95 extinguiu a sistemática de correção monetária para os } \\
\text { exercícios sociais iniciados em } 1^{\circ} \text { de janeiro de 1996, conforme } \\
\text { redação de seu artigo } 4^{\circ} \text { : "Fica revogada a correção monetária das } \\
\text { demonstrações financeiras de que tratam a Lei } 7.799 \text {, de } 10 \text { de julho de } \\
\text { 1989, e o artigo } 1^{\circ} \text { da Lei } n^{\circ} 8200 \text {, de } 28 \text { de junho de } 1991 \text {. Parágrafo } \\
\text { único: Fica vedada a utilização de qualquer sistema de correção } \\
\text { monetária de demonstrações financeiras, inclusive para fins } \\
\text { societários". }\end{array}$ \\
\hline
\end{tabular}




\begin{tabular}{|c|l|}
\hline Ano & REGULAMENTAÇÃO \\
\hline $\begin{array}{c}\text { Lei } n^{\circ} \\
9.430 / 96\end{array}$ & $\begin{array}{l}\text { Regulamentação da legislação do imposto de renda e outros tributos e } \\
\text { contribuições federais a partir de 1997. Esta Lei não alterou o disposto } \\
\text { na Lei 9.249/95 com relação à correção monetária. Quanto à questão } \\
\text { dos juros sobre o capital próprio, a Lei 9.430/96 revogou a possibilidade } \\
\text { de considerá-los como dedutíveis, caso fossem incorporados ao capital } \\
\text { social ou mantidos em conta de reserva, estabelecendo sua } \\
\text { dedutibilidade somente no caso de pagamento (ou crédito) ao acionista. }\end{array}$ \\
\hline
\end{tabular}

Complementando o quadro anterior, pode-se citar os seguintes normativos, também ligados ao assunto:

\begin{tabular}{|c|c|}
\hline Ano & REGULAMENTAÇÃO \\
\hline $\begin{array}{l}\text { Resolução } \\
\text { CFC no } \\
750 / 93\end{array}$ & $\begin{array}{l}\text { Regulamenta os Princípios Fundamentais de Contabilidade, dentre os } \\
\text { quais está o Princípio da Atualização Monetária. }\end{array}$ \\
\hline $\begin{array}{l}\text { Instrução } \\
\text { CVM n } \\
248 / 96\end{array}$ & $\begin{array}{l}\text { A Instrução CVM n }{ }^{\circ} 248 \text {, de } 29.03 .96 \text {, tornou facultativa a elaboração } \\
\text { e divulgação das demonstrações contábeis em moeda de capacidade } \\
\text { aquisitiva constante. }\end{array}$ \\
\hline $\begin{array}{l}\text { Resolução } \\
\text { CFC no- } \\
900 / 01\end{array}$ & $\begin{array}{l}\text { Dispõe sobre a aplicação do Princípio da Atualização Monetária, que } \\
\text { passa a ser compulsória somente quando a taxa inflacionária } \\
\text { acumulada no período de três anos superar os } 100 \% \text {. }\end{array}$ \\
\hline
\end{tabular}

Dentre os normativos citados nos quadros anteriores, destaca-se a Lei 6.404/76, a Lei das Sociedades por Ações, que instituiu a Correção Monetária do Balanço, que consistia na correção dos itens do Ativo Permanente e do Patrimônio Líquido e a diferença apurada entre o valor da correção desses dois 
grupos era refletida no resultado do exercício e considerada para fins societários e de tributação.

A Correção Monetária do Balanço era uma metodologia bastante simples e de fácil aplicabilidade, mostrando-se eficaz desde que os índices de inflação não fossem muito altos, pois deixava de reconhecer o efeito inflacionário sobre itens não monetários como os estoques finais, pelo fato de esses serem classificados fora do Ativo Permanente, e também não ajustava a valor presente os valores a receber e a pagar, que em situações de alta inflação embutiam expectativas de inflação futura e taxas de juros.

A fim de corrigir essas distorções surgiu no meio acadêmico a metodologia da Correção Monetária Integral, que diferentemente da metodologia anterior, corrigia cada linha das demonstrações contábeis, apresentando-as em moeda da data do encerramento do exercício. A Correção Integral é assim definida por ludícibus e Marion ${ }^{34}$ :

"Sistema que objetiva produzir demonstrações financeiras em uma única moeda para todos os itens componentes dessas demonstrações, além de explicar os efeitos da inflação sobre cada conta. Para tanto, é necessária a adoção de um índice que reflita a perda do poder de compra da moeda corrente e pelo mesmo sejam atualizados os saldos contábeis e reconhecidos seus efeitos no resultado do exercício."

A Correção Monetária Integral foi instituída pela Comissão de Valores Mobiliários, através da Instrução CVM n 64/87 e aperfeiçoada por normativos posteriores, consolidados pela Instrução CVM n 191/92, conforme detalhado

\footnotetext{
${ }^{34}$ IUDÍCIBUS, Sérgio de; MARION, José Carlos. Dicionário de Termos de Contabilidade. São Paulo: Atlas: 2001, p.49.
} 
no quadro anterior. Tal metodologia era obrigatória para as sociedades anônimas de capital aberto, embora tenha sido largamente utilizada por outras empresas não obrigadas ao seu uso. A respeito dessa metodologia Barbieri ${ }^{35}$ comenta:

"Podemos afirmar que a qualidade das demonstrações foi sensivelmente melhorada. Ao longo do tempo, a metodologia da correção integral, por intermédio da publicação de várias outras Instruções, sofreu uma evolução, até que em julho de 1992 foi editada a Instrução CVM $n^{\circ} 191$, atingindo assim um alto grau de perfeição nas demonstrações contábeis quando elaboradas em conformidade com ela."

A Correção Monetária Integral também foi reconhecida em nível internacional como uma metodologia eficiente para corrigir os efeitos da inflação nas demonstrações contábeis, conforme afirma Santos ${ }^{36}$ :

"Destaque-se que a Correção Monetária Integral foi aceita e recomendada para todos os países componentes das Organizações das Nações Unidas - ONU em março de 1989. O Internacional Accounting Standards Committee - IASC (hoje International Accounting Standards Board - IASB), que se utiliza de modelo mais simples, declarou, conforme consta dos registros das reuniões do ISAR/GROUP/1989, que o modelo brasileiro de reconhecimento da inflação nas demonstrações contábeis era o mais avançado que se tinha conhecimento."

Desde o advento do Plano Real, que em $1^{\circ}$ de julho de 1994 criou uma nova moeda, o Real, equivalente a 2.750 Cruzeiros Reais em 1994, a moeda nacional passou a experimentar certa estabilidade, com a conseqüente queda nos índices de inflação até então apresentados.

\footnotetext{
${ }^{35}$ BARBIERI, Geraldo. Lucro Inflacionário e Fluxo de Caixa. Boletim IOB - Temática Contábil e Balanços. Bol. 45, 1995.

36 SANTOS, Ariovaldo dos. Resultado do Exercício: As Empresas Localizadas em Países com Baixas Taxas de Inflação São ou Não Afetadas? V Congresso Internacional de Custos. Acapulco, Gro. México. Julho 1997.
} 
Neste cenário de aparente estabilidade da economia, foi aprovada a Lei $n^{\circ}$ 9.249/95, que em seu art. $4^{\circ}$, parágrafo único, vetou a utilização de qualquer sistema de correção monetária de demonstrações contábeis a partir de $1^{\circ}$ de janeiro de 1996, conforme a Lei $n^{\circ}$ 9.249, de 26 de dezembro de 1995:

"Fica revogada a correção monetária das demonstrações financeiras de que tratam a Lei 7.799, de 10 de julho de 1989, e 0 artigo $1^{\circ}$ da Lei $n^{\circ} 8.200$, de 28 de junho de 1991.

Parágrafo Único: Fica vedada a utilização de qualquer sistema de correção monetária de demonstrações financeiras, inclusive para fins societários."

A falta de reconhecimento dos efeitos inflacionários nas demonstrações contábeis vem causando sérias distorções dos números apresentados pela Contabilidade, apesar dos baixos índices de inflação observados após o Plano Real. Neste sentido, Santos ${ }^{37}$ comenta:

"Se tomarmos uma inflação de $5 \%$ ao ano, num período de 10 anos teremos $62,9 \%$ de inflação acumulada. Se para a mesma taxa de inflação ampliarmos o período para 20 anos a inflação acumulada será de $165,3 \%$.

Os números acima demonstram que a longo prazo, mesmo para os países onde a inflação é considerada baixa, a contabilidade, quando não devidamente atualizada, acaba por apresentar defasagens bastante sensíveis."

Mesmo sem considerar o efeito cumulativo da inflação, os resultados divulgados anualmente pelas companhias podem apresentar sérias distorções, conforme comprovou o Professor Dr. Ariovaldo dos Santos ${ }^{38}$, em trabalho

\footnotetext{
${ }^{37}$ SANTOS, Ariovaldo dos. Alguns Efeitos da Utilização de Índices Inadequados na Correção dos Balanços de Empresas Estrangeiras no Brasil. Tese de Doutoramento apresentada à Faculdade de Economia, Administração e Contabilidade da Universidade de São Paulo. 1993. p.26.

${ }^{38}$ SANTOS, Ariovaldo dos. Pior que decepção! Dá para entender os resultados publicados pela empresas? Boletim IOB - Temática Contábil e Balanços. Bol. 19, 2002, p. 5.
} 
recentemente divulgado, onde comparou as demonstrações contábeis de empresas brasileiras, publicadas em 1999 e 2000, de acordo com a Lei $n^{\circ}$ 9.249/95, com as demonstrações ajustadas pelo efeito da inflação do período, tendo obtido os seguintes resultados:

\begin{tabular}{|l|r|r|r|}
\hline \multicolumn{3}{|c|}{ Comparativo dos Resultados: Ajustado X Legal } \\
\hline \multicolumn{3}{|c|}{ Valores Nominais } \\
\hline & \multicolumn{2}{|c|}{$\begin{array}{c}\text { Lucro/Prejuízo } \\
\text { Líquido }\end{array}$} & $\begin{array}{c}\text { Diferença } \\
\text { Ajustado/Legal }\end{array}$ \\
\hline Empresas & Ajustado & \multicolumn{1}{c|}{ Legal } & (em \%) \\
\hline Sansuy & 11.345 & 2.853 & 297,7 \\
\hline Sabesp & 454.564 & -235.448 & 293,1 \\
\hline Editora Abril & 67.648 & 20.526 & 229,6 \\
\hline Staroup & 860 & -1.484 & 158,0 \\
\hline Arteb & 2.407 & -11.583 & 120,8 \\
\hline Usina São Martinho & -14.874 & -43.330 & 65,7 \\
\hline Santher & -14.794 & -24.721 & 40,2 \\
\hline Copesul & 175.120 & 139.766 & 25,3 \\
\hline Technos & 21.354 & 29.172 & $-26,8$ \\
\hline Mococa Metalúrgica & 6.428 & 9.074 & $-29,2$ \\
\hline B.GROB & 9.850 & 15.390 & $-36,0$ \\
\hline Ponto Frio & 13.671 & 43.542 & $-68,6$ \\
\hline Montcalm & -93 & 5.833 & $-101,6$ \\
\hline
\end{tabular}




\begin{tabular}{|l|r|r|r|}
\hline \multicolumn{3}{|c|}{ Comparativo dos Resultados: Ajustado X Legal } \\
\hline \multicolumn{3}{|c|}{ Valores Nominais } \\
\hline & \multicolumn{2}{|c|}{$\begin{array}{c}\text { Lucro/Prejuízo } \\
\text { Líquido }\end{array}$} & $\begin{array}{c}\text { Diferença } \\
\text { Ajustado/Legal }\end{array}$ \\
\hline Empresas & Ajustado & \multicolumn{1}{c|}{ Legal } & (em \%) \\
\hline Arteb & 13.457 & -3.461 & 488,8 \\
\hline Staroup & 3.073 & 1.724 & 78,2 \\
\hline Santher & 20.638 & 12.335 & 67,3 \\
\hline Sansuy & 8.509 & 5.300 & 60,5 \\
\hline Usina São Martinho & -14.602 & -34.066 & 57,1 \\
\hline Sabesp & 711.260 & 521.435 & 36,4 \\
\hline Copesul & 128.964 & 99.357 & 29,8 \\
\hline Copel & 430.388 & 430.603 & 0,0 \\
\hline TV Paranaense & 14.145 & 14.871 & $-4,9$ \\
\hline Makro & 64.609 & 69.522 & $-7,1$ \\
\hline Technos & 15.510 & 23.584 & $-34,2$ \\
\hline Mococa Metalúrgica & 5.762 & 9.091 & $-36,6$ \\
\hline
\end{tabular}

Os quadros anteriores evidenciam que, mesmos em períodos de baixa inflação, como foram 1999 e 2000, o resultado apresentado nas demonstrações contábeis pode ser distorcido se não for aplicado às demonstrações contábeis nenhum método de correção monetária.

Como conseqüência da extinção da correção monetária das demonstrações contábeis, duas situações podem se apresentar do ponto de vista fiscal, conforme a seguir:

a) empresas com patrimônio líquido superior ao ativo permanente: tais empresas apresentarão um lucro superior ao efetivamente ocorrido pelo fato de deixar de reconhecer uma despesa correspondente ao saldo devedor da correção monetária, o que ocasiona o pagamento 
de imposto de renda e contribuição social sobre uma base de cálculo superestimada;

b) empresas em que o valor do ativo permanente supere o patrimônio líquido: essas empresas deixarão de registrar uma receita correspondente ao saldo credor da correção monetária, redundando em um lucro subestimado e o pagamento de impostos sobre o lucro a um valor inferior ao real, num primeiro momento, no entanto, em períodos posteriores, sua carga tributária vai sendo elevada gradualmente em função da não atualização das despesas de depreciação, amortização e exaustão, conseqüência da não correção do ativo imobilizado.

Ambas as situações são desfavoráveis para as empresas, conforme comentam Barbieri e Santos ${ }^{39}$ :

- "As empresas na situação de saldo credor de correção teriam o benefício da postergação do Imposto de Renda, mas serão mais penalizadas a médio e longo prazos, quando da baixa de seus ativos por meio de depreciações, amortizações, alienações etc. Será que essas empresas estarão dispostas a esse futuro sacrifício? (...)

- Para as empresas na situação de resultados devedores na conta de correção monetária de balanços, a tributação adicional de impostos será tida como normal, ou estarão elas, em todos os momentos, recorrendo à justiça?"

Diante dessas observações é possível entender porque a Receita Federal reduziu em 10 pontos percentuais (de $25 \%$ para $15 \%$ ) a alíquota do

\footnotetext{
${ }^{39}$ BARBIERI, Geraldo; SANTOS, Ariovaldo dos. Fim da Correção Monetária de Balanços e início da Taxa de Juros de Longo Prazo (TJLP) sobre o capital próprio - Alguns de seus principais efeitos. Boletim IOB Temática Contábil e Balanços. Bol. 16, 1996, p.153.
} 
imposto de renda e permitiu a dedução da despesa com o pagamento de juros sobre o capital próprio, de acordo com os limites estipulados no âmbito da Lei $n^{0}$ 9.249/95. Também foram reduzidas as taxas relativas aos adicionais de imposto de renda, que eram de $12 \%$ e $18 \%$, para uma taxa única de $10 \%$.

A Comissão de Valores Mobiliários pronunciou-se a respeito da extinção da correção monetária através da Instrução CVM n² 248, de 29 de março de 1996 e do Parecer de Orientação $n^{0} 29$, de 11 de abril do mesmo ano, onde faculta às companhias de capital aberto a elaboração e divulgação em notas explicativas de demonstrações contábeis em moeda de capacidade aquisitiva constante, quando julgadas relevantes pelos administradores e auditores responsáveis. Seguindo esta orientação, várias empresas publicam em notas explicativas suas demonstrações contábeis ajustadas pela metodologia da Correção Monetária Integral.

O Banco Central do Brasil, que regula as instituições participantes do Sistema Financeiro Nacional, vetou a contabilização da correção monetária do balanço a partir de $1^{\circ}$ de janeiro de 1996 , através da Circular $n^{\circ} 2.682$, de 30 de abril de 1996.

Em Março de 2001 o Conselho Federal de Contabilidade (CFC) emitiu a Resolução no 900/01 onde proíbe a atualização monetária das demonstrações contábeis regulares, admitindo-a somente em demonstrações complementares, conforme seu Art. $3^{\circ}$ a seguir:

"Art. 3o - Quando a taxa inflacionária acumulada no triênio for inferior a $100 \%$, a aplicação do Princípio da Atualização Monetária somente poderá ocorrer em demonstrações contábeis de natureza 
complementar às demonstrações de natureza corrente, derivadas da escrituração contábil regular."

O Instituto Brasileiro de Auditores Independentes (Ibracon), através de sua Interpretação Técnica $n^{\circ}$ 02/2002, deliberou a retirada da aderência das demonstrações contábeis aos Princípios Fundamentais de Contabilidade se as demonstrações suplementares com atualização monetária forem levantadas em um período em que a inflação for inferior ao patamar de 100\% em três anos.

Sobre o assunto Martins ${ }^{40}$ fez os seguintes comentários:

"É sabido que outras razões foram levantadas para a emissão do pronunciamento do CFC e do Ibracon, algumas delas vinculadas à conversão das demonstrações contábeis de algumas empresas brasileiras aos princípios contábeis utilizados nos EUA. (...)"

E acrescentou:

"Estamos preocupados com a medição da riqueza criada e com a possibilidade de a Contabilidade servir como instrumento para ajudar a todos a ampliar a sua geração; há de fato um problema com a tributação, que é a distribuição desta riqueza. Mas fiquemos com a produção do PIB brasileiro e com o papel da Contabilidade como instrumento gerencial nesta análise."

A partir desses comentários e do posicionamento de cada um dos órgãos aqui mencionados, observa-se a impropriedade dessas medidas, as quais não demonstram compromisso com a relevância da informação contábil divulgada pelas empresas.

\footnotetext{
40 MARTINS, Eliseu. A posição do Conselho Federal de Contabilidade com relação à atualização monetária dos balanços: decepção! Boletim IOB - Temática Contábil e Balanços. Bol. 15 e 16, 2002. p.6.
} 


\section{CAPÍTULO 4}

\section{Análise dos dados}

Neste capítulo serão analisadas as demonstrações contábeis publicadas de empresas brasileiras que negociavam suas ações na Bolsa de Valores de Nova lorque no período de 1996 a 1999 e, por esse motivo, publicavam também demonstrações contábeis de acordo com as normas norte-americanas (US GAAP).

Para essa análise foram escolhidas as empresas que operam há mais tempo naquela Bolsa, excluídas algumas empresas ligadas ao segmento de telecomunicações, em função das privatizações, fusões e reorganizações por que passaram tais empresas no período analisado, o que inviabilizaria algumas comparações com as demonstrações contábeis dessas empresas.

A amostra é composta das cinco empresas a seguir:

- Aracruz Celulose S.A.

- Companhia Siderúrgica Nacional - CSN

- Companhia Paranaense de Energia - COPEL

- COPENE - Petroquímica do Nordeste S.A.

- Embratel Participações S.A.

A análise foi efetuada da seguinte forma: 
a) foram traduzidas para dólares as demonstrações contábeis publicadas pelas empresas, de acordo com a legislação societária brasileira e em moeda de capacidade aquisitiva constante, relativas ao período de 1996 a 1999. Para efetuar a tradução foram usadas as taxas de câmbio correntes em 31 de dezembro de cada ano, divulgadas pelo Banco Central do Brasil;

b) em seguida foram comparadas as demonstrações em dólares traduzidas a partir das demonstrações elaboradas de acordo com a legislação societária, com as demonstrações traduzidas a partir das demonstrações em moeda constante, a fim de levantar as diferenças pelo não reconhecimento dos efeitos da inflação nas demonstrações elaboradas de acordo com a legislação societária brasileira;

c) foram ainda reconciliadas algumas contas das demonstrações em dólares, obtidas a partir das traduções efetuadas, com as demonstrações publicadas nos EUA de acordo com os US GAAP, com o objetivo de evidenciar eventuais diferenças entre as práticas contábeis brasileiras e norte-americanas, com base nas informações prestadas pelas empresas em notas explicativas. 


\subsection{Aracruz Celulose S.A.}

No caso da Aracruz Celulose S.A., foram analisadas apenas as demonstrações contábeis relativas aos exercícios de 1996 e 1997, visto que a partir de 1998 a empresa não mais publicou demonstrações em moeda de capacidade aquisitiva constante.

Nas tabelas a seguir encontram-se os valores traduzidos para dólares do balanço patrimonial e da demonstração de resultado dos dois exercícios, na qual verificam-se diferenças em valores absolutos e relativos encontradas na comparação das demonstrações pela legislação societária e em moeda constante.

Dentre os itens que apresentaram variações nas demonstrações em moeda constante, em relação às demonstrações pela legislação societária, destacam-se os seguintes no ano de 1996:

- Estoques - verificou-se um acréscimo pela correção monetária de $5,49 \%$ no valor dos estoques finais da empresa;

- Ativo Permanente - a correção monetária do Ativo Permanente aumentou em $9,10 \%$ o subgrupo Imobilizado e em 7,69\% o Diferido;

- Exigível a longo prazo - o incremento de 2,53\% no saldo deste grupo refere-se à conta "Imposto de renda e contribuição social diferidos", no valor de $R \$ 20$ milhões, apurado pela aplicação da correção 
integral, que consta somente do balanço em moeda constante, conforme se observa na conciliação do patrimônio líquido (tabela 3).

- Capital integralizado e Reservas - foram apuradas as variações de 9,22\% e 9,31\% para "Capital integralizado" e "Reservas", respectivamente, relativas à correção monetária dos saldos dessas contas;

- Lucros (prejuízos) acumulados - esta conta teve uma variação significativa, tendo evoluído de um prejuízo de $R \$ 10$ milhões para um lucro de $\mathrm{R} \$ 1$ milhão, que pode ter tido como causa o lucro do período apurado pelo método da correção integral, o qual teve um acréscimo em torno de $R \$ 32$ milhões em relação ao lucro apurado de acordo com a legislação societária, conforme se observa na Demonstração do Resultado de 1996 e na conciliação do lucro líquido e do patrimônio líquido (tabelas 2 e 3);

- Receitas e Despesas Financeiras - foram apuradas as variações negativas de $-36,80 \%$ para as receitas financeiras e de $-56,49 \%$ para as despesas financeiras, revelando que, na Demonstração do Resultado elaborada de acordo com a legislação societária, os valores dessas contas não representavam apenas juros reais, mas embutiam também taxas de inflação.

No ano de 1997 destacam-se as variações dos seguintes itens: 
- Estoques - verificou-se um acréscimo pela correção monetária de $11,61 \%$ no valor dos estoques finais da empresa;

- Créditos tributários (longo prazo) - este item apresentou uma redução de $20,98 \%$ no balanço em moeda constante, relativa ao ajuste dos tributos incidentes sobre os efeitos inflacionários, conforme consta das notas explicativas e da conciliação do patrimônio Líquido (tabela 7);

- Ativo Permanente - em 1997 a correção monetária do Ativo Permanente aumentou em $23,50 \%$ o subgrupo Investimentos, em $16,53 \%$ o Imobilizado e em $14,03 \%$ o Diferido;

- Exigível a longo prazo - o incremento de $6,40 \%$ no saldo deste grupo refere-se à conta "Imposto de renda e contribuição social diferidos", no valor de $\mathrm{R} \$ 54.564$ mil, apurado a partir do ajuste dos tributos incidentes sobre os efeitos inflacionários, pela aplicação da correção integral, conforme consta das notas explicativas e da conciliação do patrimônio Líquido (tabela 7);

- Participação de Minoritários - este item apresentou um acréscimo de $3,92 \%$ no balanço em moeda constante, relativo à correção monetária do período;

- Capital integralizado e Reservas - foram apuradas as variações de $17,65 \%$ e $18,34 \%$ para "Capital integralizado" e "Reservas", 
respectivamente, relativas à correção monetária dos saldos dessas contas;

- Lucros (prejuízos) acumulados - esta conta teve um acréscimo em seu saldo de $542,18 \%$ no balanço em moeda constante, enquanto que o lucro do exercício teve um acréscimo de $80,12 \%$, em função dos ajuste pelos efeitos inflacionários do período, conforme se observa na Demonstração do Resultado de 1997 e na conciliação do lucro líquido e do patrimônio líquido (tabelas 6 e 7);

- Despesas Financeiras (líquidas) - em 1997 esta conta foi apresentada pelo resultado financeiro líquido (despesas menos receitas financeiras), tendo sido apurada uma variação de $411,62 \%$ na Demonstração de Resultado em moeda constante, passando de um saldo negativo (despesa) de $\mathrm{R} \$ 9.737 \mathrm{mil}$, para um saldo positivo (receita) de $\mathrm{R} \$ 30.342$ mil, o que revela a distorção causada pelo não reconhecimento dos efeitos da inflação sobre estas contas, as quais passam a acumular não somente juros reais, mas também taxas de inflação.

A Aracruz não apresentou a reconciliação do patrimônio líquido do balanço em US GAAP, de modo que não foi possível evidenciar em termos monetários os efeitos dos ajustes efetuados nas demonstrações contábeis a fim de adequá-las às exigências das normas contábeis norte-americanas (US GAAP). 
No entanto, nas tabelas 4 e 8 , foi feita uma tentativa de comparar os saldos do balanço em US GAAP, divulgado nos EUA, com os saldos do balanço em moeda constante, divulgado no Brasil e traduzido para dólares na coluna (B) das tabelas 1 e 5 .

No ano de 1996 (tabela 4) os saldos do Disponível e Aplicações Financeiras, assim como o de Depósitos Judiciais, praticamente coincidiram no balanço em US GAAP com o balanço em moeda constante, sendo que para as demais contas não se conseguiu comparar os valores nos dois balanços.

Um destaque especial deve ser feito para o subgrupo Diferido, o qual não encontra correspondente no balanço em US GAAP, visto que, os gastos que são comumente registrados no Diferido pelas normas contábeis brasileiras são reconhecidos como despesas do período em que forem incorridos, de acordo com as normas norte-americanas. De acordo com suas notas explicativas, a Aracruz registrou no Diferido os seguintes itens:

- Gastos pré-operacionais;

- Melhoramentos em propriedades florestais;

- Benfeitoria em prédios de terceiros;

- Despesas administrativas e melhoria de produto; e

- Outras.

No ano de 1997 (tabela 8) foram comparados nos dois balanços os saldos de Títulos e Valores Mobiliários, Créditos Tributários e Depósitos Judiciais, sendo que para as demais contas não se conseguiu comparar os 
valores, com destaque para o Imposto de Renda Diferido (Deferred income tax, net), que consta do balanço em US GAAP e não consta do balanço em moeda constante, e para os subgrupos Investimentos e Diferido, os quais apresentam valores no balanço em moeda constante e não têm correspondente no balanço em US GAAP. 
Tabela 1 - ARACRUZ CELULOSE S. A.

Balanço Patrimonial Consolidado em 31 de Dezembro de 1996

\begin{tabular}{|c|c|c|c|c|c|c|}
\hline CONTAS & $\begin{array}{c}\text { Legislação } \\
\text { Societária em } \\
R \$ \text { mil }\end{array}$ & $\begin{array}{c}\text { (A) } \\
\text { Legislação } \\
\text { Societária } \\
\text { em US\$ mil }\end{array}$ & $\begin{array}{c}\text { Moeda } \\
\text { Constante em } \\
\mathrm{R} \$ \text { mil }\end{array}$ & $\begin{array}{c}\text { (B) } \\
\text { Moeda } \\
\text { Constante } \\
\text { US\$ mil }\end{array}$ & $\begin{array}{c}\text { Variação } \\
\text { absoluta } \\
\text { (B - A) } \\
\text { em US\$ mil }\end{array}$ & $\begin{array}{c}\text { Variação } \\
\% \text { (B/A -1) }\end{array}$ \\
\hline \multicolumn{7}{|l|}{ ATIVO } \\
\hline Disponível + Aplicações Financeiras & 791.000 & 761.016 & 791.000 & 761.016 & - & $0,00 \%$ \\
\hline Contas a Receber & 64.000 & 61.574 & 64.000 & 61.574 & - & $0,00 \%$ \\
\hline Demais Contas a Receber & 7.000 & 6.735 & 7.000 & 6.735 & - & $0,00 \%$ \\
\hline Estoques & 91.000 & 87.551 & 96.000 & 92.361 & 4.810 & $5,49 \%$ \\
\hline Adiantamentos a Fornecedores & 43.000 & 41.370 & 43.000 & 41.370 & - & $0,00 \%$ \\
\hline Outros & 63.000 & 60.612 & 63.000 & 60.612 & - & $0,00 \%$ \\
\hline Créditos & 87.000 & 83.702 & 87.000 & 83.702 & - & $0,00 \%$ \\
\hline Depósitos Judiciais & 30.000 & 28.863 & 30.000 & 28.863 & - & $0,00 \%$ \\
\hline Outros & 9.000 & 8.659 & 9.000 & 8.659 & - & $0,00 \%$ \\
\hline Imobilizado & 2.592 .000 & 2.493.746 & 2.828 .000 & 2.720 .800 & 227.054 & $9,10 \%$ \\
\hline Diferido & 52.000 & 50.029 & 56.000 & 53.877 & 3.848 & $7,69 \%$ \\
\hline Total do Ativo & 3.829 .000 & 3.683 .856 & 4.074 .000 & 3.919 .569 & 235.713 & \\
\hline \multicolumn{7}{|l|}{ PASSIVO } \\
\hline Circulante & 734.000 & 706.177 & 734.000 & 706.177 & - & $0,00 \%$ \\
\hline Exigível a Longo Prazo & 790.000 & 760.054 & 810.000 & 779.296 & 19.242 & $2,53 \%$ \\
\hline \multicolumn{7}{|l|}{ Patrimônio Líquido: } \\
\hline Capital integralizado & 1.854 .000 & 1.78 & 2.025 .000 & 1.948 .239 & 164.518 & $9,22 \%$ \\
\hline Reservas de Capital + Reserva & 462.000 & 444.487 & 505.000 & 485.857 & 41.370 & $9,31 \%$ \\
\hline Lucros (prejuízos) acumulados & $(10.000)$ & (9.621) & 1.000 & 962 & 10.583 & $-110,00 \%$ \\
\hline Ações em Tesouraria & $(1.000)$ & (962) & $(1.000)$ & (962) & & $0,00 \%$ \\
\hline Total do Patrimônio Líquido & 2.305 .000 & 2.217 .626 & 2.530 .000 & 2.434 .097 & 216.471 & $9,76 \%$ \\
\hline Total do Passivo & 3.829 .000 & 3.683 .856 & 4.074 .000 & 3.919 .569 & 235.713 & \\
\hline
\end{tabular}

Fonte: Diário Oficial do Estado do Rio de Janeiro, 25.02.97.

Taxa de câmbio divulgada pelo Banco Central do Brasil para 31.12.1996: US\$1,00 = $\mathbf{R} \$ \mathbf{1 , 0 3 9 4}$ 
Tabela 2 - ARACRUZ CELULOSE S. A.

Demonstração do Resultado para o Exercício findo em 31 de Dezembro de 1996

\begin{tabular}{|c|c|c|c|c|c|c|}
\hline CONTAS & \begin{tabular}{|c|} 
Legislação \\
Societária em \\
$\mathrm{R} \$$ mil
\end{tabular} & \begin{tabular}{|c|} 
(A) \\
Legislação \\
$\begin{array}{c}\text { Societária em } \\
\text { US\$ mil }\end{array}$ \\
\end{tabular} & $\begin{array}{l}\text { Moeda } \\
\text { Constante } \\
\text { em } R \$ \text { mil }\end{array}$ & \begin{tabular}{|c|} 
(B) \\
Moeda \\
$\begin{array}{c}\text { Constante em } \\
\text { US\$ mil }\end{array}$ \\
\end{tabular} & $\begin{array}{c}\text { Variação } \\
\text { absoluta } \\
\text { (B - A) } \\
\text { em US\$ mil }\end{array}$ & \begin{tabular}{|c|} 
Variação \% \\
$(B / A-1)$
\end{tabular} \\
\hline Receita líquida de vendas & 493.000 & 474.312 & 513.000 & 493.554 & 19.242 & $4,06 \%$ \\
\hline Custo dos produtos vendidos & $(392.000)$ & $(377.141)$ & $(409.000)$ & $(393.496)$ & $(16.356)$ & $4,34 \%$ \\
\hline Lucro bruto & 101.000 & 97.171 & 104.000 & 100.058 & 2.886 & $2,97 \%$ \\
\hline Despesas comerciais & $(38.000)$ & $(36.560)$ & $(40.000)$ & $(38.484)$ & $(1.924)$ & $5,26 \%$ \\
\hline Despesas administrativas & $(48.000)$ & $(46.180)$ & $(50.000)$ & $(48.105)$ & $(1.924)$ & $4,17 \%$ \\
\hline Honorários dos administradores & $(3.000)$ & $(2.886)$ & $(3.000)$ & (2.886) & - & \\
\hline Despesas com litígios & $(4.000)$ & $(3.848)$ & $(4.000)$ & (3.848) & - & \\
\hline $\begin{array}{l}\text { Provisão p/participação dos empregados nos } \\
\text { resultados e outras despesas (receitas) } \\
\text { operacionais }\end{array}$ & 7.000 & 6.735 & 10.000 & 9.621 & 2.886 & $42,86 \%$ \\
\hline Receitas financeiras & 269.000 & 258.803 & 170.000 & 163.556 & $(95.247)$ & $-36,80 \%$ \\
\hline Despesas financeiras & $(239.000)$ & $(229.940)$ & $(104.000)$ & $(100.058)$ & 129.883 & $-56,49 \%$ \\
\hline Lucro operacional & 45.000 & 43.294 & 83.000 & 79.854 & 36.560 & $84,44 \%$ \\
\hline Resultado não operacional & $(4.000)$ & $(3.848)$ & $(5.000)$ & $(4.810)$ & $(962)$ & $25,00 \%$ \\
\hline Lucro antes do IR e Contribuição Social & 41.000 & 39.446 & 78.000 & 75.043 & 35.597 & $90,24 \%$ \\
\hline IR e Contribuição Social & 6.000 & 5.773 & 1.000 & 962 & $(4.810)$ & $-83,33 \%$ \\
\hline Lucro (Prejuízo) Líquido do Exercício & 47.000 & 45.218 & 79.000 & 76.005 & 30.787 & $68,09 \%$ \\
\hline
\end{tabular}

Fonte: Diário Oficial do Estado do Rio de Janeiro, 25.02.97.

Taxa de câmbio divulgada pelo Banco Central do Brasil para 31.12.1996: US\$1,00 = R\$ $\quad \mathbf{1 , 0 3 9 4}$ 
Tabela 3 - Conciliação do Lucro Líquido e do Patrimônio Líquido em 1996

\begin{tabular}{|c|c|c|}
\hline & \multicolumn{2}{|c|}{ Valores em $\mathrm{R} \$$ mil } \\
\hline & $\begin{array}{l}\text { Lucro } \\
\text { Líquido }\end{array}$ & $\begin{array}{c}\text { Patrimônio } \\
\text { Líquido }\end{array}$ \\
\hline Pela legislação societária................................ & 47.000 & 2.305 .000 \\
\hline \multicolumn{3}{|l|}{ Atualização monetária de: } \\
\hline Estoques................ & 6.000 & 6.000 \\
\hline 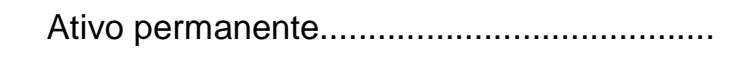 & 239.000 & 239.000 \\
\hline 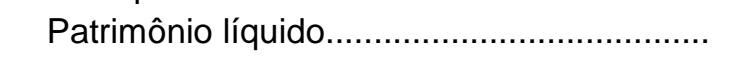 & $(210.000)$ & \\
\hline Contribuição social sobre efeitos inflacionários.. & $(3.000)$ & $(20.000)$ \\
\hline Em moeda de poder aquisitivo constante..... & 79.000 & 2.530 .000 \\
\hline
\end{tabular}

Fonte: Diário Oficial do Estado do Rio de Janeiro, 25.02.97.

${ }^{*}$ *) O valor de $\mathrm{R} \$ 20.000$ mil, corresponde ao acréscimo na conta Imposto de Renda e Contribuição Social Diferidos no Passivo Exigível a Longo Prazo. 
Tabela 4 - ARACRUZ CELULOSE S. A

Balanço Patrimonial Consolidado em US GAAP em 31 de Dezembro de 1996

\begin{tabular}{|c|c|c|c|c|}
\hline \multicolumn{2}{|r|}{ CONTAS } & \multirow{2}{*}{$\begin{array}{c}\text { (A) } \\
\text { Moeda } \\
\text { Constante } \\
\text { US\$ mil }\end{array}$} & \multirow{2}{*}{$\begin{array}{c}\text { (B) } \\
\text { US GAAP } \\
\text { publicado } \\
\text { em US\$ mil }\end{array}$} & \multirow[b]{2}{*}{$\begin{array}{l}\text { Variação \% } \\
(B / A-1)\end{array}$} \\
\hline $\begin{array}{c}\text { BRASIL } \\
\text { Moeda Constante }\end{array}$ & US GAAP & & & \\
\hline ATIVO & ASSETS & & & \\
\hline $\begin{array}{l}\text { Disponível + Aplicações } \\
\text { Financeiras }\end{array}$ & $\begin{array}{l}\text { Cash and cash equivalents + Bank deposits, as } \\
\text { a compensating balance }\end{array}$ & 761.016 & 762.270 & $0,16 \%$ \\
\hline $\begin{array}{l}\text { Contas a Receber + Demais } \\
\text { Contas a Receber }\end{array}$ & Accounts receivable & 68.309 & 109.938 & $60,94 \%$ \\
\hline Estoques & Inventories, net & 92.361 & 84.009 & $-9,04 \%$ \\
\hline $\begin{array}{l}\text { Adiantamentos a } \\
\text { Fornecedores + Outros }\end{array}$ & $\begin{array}{l}\text { Deferred income tax, net + Recoverable taxes } \\
+ \text { Prepaid expenses and other current assets }\end{array}$ & 101.982 & 70.344 & $-31,02 \%$ \\
\hline Créditos Tributários & Deferred income tax, net + Recoverable tax, net & 83.702 & 91.833 & $9,71 \%$ \\
\hline Depósitos Judiciais & Deposits for tax assessments & 28.863 & 28.865 & $0,01 \%$ \\
\hline Outros & Other & 8.659 & 9.382 & $8,35 \%$ \\
\hline Imobilizado & $\begin{array}{l}\text { Property, Plant and Equipment, net + Property, } \\
\text { plant and equipment held for sale, net (current } \\
\text { asset) }\end{array}$ & 2.720 .800 & 1.882 .621 & $-30,81 \%$ \\
\hline Diferido & - & 53.877 & & \\
\hline Total do Ativo & Total Assets & 3.919 .569 & 3.039 .262 & \\
\hline PASSIVO & LIABILITIES AND SHAREHOLDER'S EQUITY & & & \\
\hline Circulante & Current Liabilities & 706.177 & 678.859 & $-3,87 \%$ \\
\hline Exigível a Longo Prazo & Long-Term Liabilities & 779.296 & 760.486 & $-2,41 \%$ \\
\hline Patrimônio Líquido & Shareholder's Equity & 2.434 .097 & 1.599 .917 & $-34,27 \%$ \\
\hline Total do Passivo & Total Liabilities and Shareholder's Equity & 3.919 .569 & 3.039 .262 & \\
\hline
\end{tabular}

Fonte: O balanço em US GAAP foi obtido no site: $\underline{w w w . a r a c r u z . c o m . b r}$ 
Tabela 5 - ARACRUZ CELULOSE S. A.

Balanço Patrimonial Consolidado em 31 de Dezembro de 1997

\begin{tabular}{|c|c|c|c|c|c|c|}
\hline CONTAS & $\begin{array}{c}\text { Legislação } \\
\text { Societária em } \\
R \$ \text { mil }\end{array}$ & \begin{tabular}{|c|} 
(A) \\
Legislação \\
Societária em \\
US\$ mil
\end{tabular} & $\begin{array}{c}\text { Moeda } \\
\text { Constante } \\
\text { em } R \$ \text { mil }\end{array}$ & $\begin{array}{c}\text { (B) } \\
\text { Moeda } \\
\text { Constante } \\
\text { US\$ mil } \\
\end{array}$ & \begin{tabular}{|c|} 
Variação \\
absoluta \\
(B - A) \\
em US\$ mil
\end{tabular} & $\begin{array}{c}\text { Variação \% } \\
\text { (B/A -1) }\end{array}$ \\
\hline \multicolumn{7}{|c|}{ - } \\
\hline Disponível + Aplicações Financeiras & 30.965 & 27.736 & 30.965 & 27.736 & - & $0,00 \%$ \\
\hline Contas a Receber & 66.825 & 59.858 & 66.825 & 59.858 & - & $0,00 \%$ \\
\hline $\begin{array}{l}\text { Estoques } \\
\text { Demais Contas a Receber + Outros + } \\
\text { Créditos tributários (circulante)+ } \\
\text { Adiantamentos Fornecedores }\end{array}$ & 91.261 & 81.746 & 101.857 & 91.237 & 9.491 & $11,61 \%$ \\
\hline Títulos e Valores Mobiliários & 779.402 & 698.139 & 779.402 & 698.139 & - & $0,00 \%$ \\
\hline Créditos Tributários (longo prazo) & 178.510 & 159.898 & 141.053 & 126.346 & (33.552) & $-20,98 \%$ \\
\hline Depósitos Judiciais & 45.357 & 40.628 & 45.357 & 40.628 & - & $0,00 \%$ \\
\hline Outros (realizável a longo prazo) & 8.549 & 7.658 & 8.549 & 7.658 & - & $0,00 \%$ \\
\hline Investimentos & 366 & 328 & 452 & 405 & 77 & $23,50 \%$ \\
\hline Imobilizado & 2.665 .898 & 2.387.942 & 3.106 .646 & 2.782 .736 & 394.794 & $16,53 \%$ \\
\hline Diferido & 75.593 & 67.711 & 86.196 & 77.209 & 9.497 & $14,03 \%$ \\
\hline $\begin{array}{l}\text { Total do Ativo } \\
\text { PASSIVO }\end{array}$ & 3.984 .241 & 3.568 .829 & 4.408 .817 & 3.949 .137 & 380.308 & \\
\hline Circulante & 843.814 & 755.835 & 843.814 & 755.835 & - & $0,00 \%$ \\
\hline Exigível a Longo Prazo & 852.660 & 763.759 & 907.224 & 812.633 & 48.875 & $6,40 \%$ \\
\hline $\begin{array}{l}\text { Participação de Minoritários } \\
\text { Patrimônio Líquido: }\end{array}$ & 2.498 & 2.238 & 2.596 & 2.325 & 88 & $3,92 \%$ \\
\hline Capital integralizado & 1.854 .507 & 1.661 .149 & 2.181 .880 & 1.954 .389 & 293.240 & $17,65 \%$ \\
\hline Reservas de Capital + Reservas de Lucros & 447.818 & 401.127 & 529.964 & 474.708 & 73.581 & $18,34 \%$ \\
\hline Lucros (prejuízos) acumulados & (7.283) & $(6.524)$ & $(46.770)$ & $(41.894)$ & $(35.370)$ & $542,18 \%$ \\
\hline Ações em Tesouraria & $(9.773)$ & $(8.754)$ & $(9.891)$ & $(8.860)$ & $(106)$ & $1,21 \%$ \\
\hline Total do Patrimônio Líquido & 2.285 .269 & 2.046 .998 & 2.655 .183 & 2.378 .344 & 331.345 & $16,19 \%$ \\
\hline Total do Passivo & 3.984 .241 & 3.568 .829 & 4.408 .817 & 3.949 .137 & 380.308 & \\
\hline
\end{tabular}

Fonte: Jornal do Comércio, 19.02.98.

Taxa de câmbio divulgada pelo Banco Central do Brasil para 31.12.1997: $\quad$ US\$1,00 = R \$ $\quad \mathbf{1 , 1 1 6 4}$ 
Tabela 6 - ARACRUZ CELULOSE S. A.

Demonstração do Resultado para o Exercício findo em 31 de Dezembro de 1997

\begin{tabular}{|c|c|c|c|c|c|c|}
\hline CONTAS & $\begin{array}{l}\text { Legislação } \\
\text { Societária em } \\
\mathrm{R} \$ \text { mil }\end{array}$ & \begin{tabular}{|c|} 
(A) \\
Legislação \\
$\begin{array}{c}\text { Societária em } \\
\text { US\$ mil }\end{array}$ \\
\end{tabular} & $\begin{array}{l}\text { Moeda } \\
\text { Constante } \\
\text { em } R \$ \text { mil }\end{array}$ & \begin{tabular}{|c|} 
(B) \\
Moeda \\
$\begin{array}{c}\text { Constante em } \\
\text { US\$ mil }\end{array}$ \\
\end{tabular} & $\begin{array}{c}\text { Variação } \\
\text { absoluta } \\
(B-A) \\
\text { em US\$ mil }\end{array}$ & $\begin{array}{c}\text { Variação \% } \\
(B / A-1)\end{array}$ \\
\hline Receita líquida de vendas & 536.826 & 480.855 & 553.449 & 495.744 & 14.890 & $3,10 \%$ \\
\hline Custo dos produtos vendidos & $(400.659)$ & $(358.885)$ & $(423.782)$ & $(379.597)$ & $(20.712)$ & $5,77 \%$ \\
\hline Lucro bruto & 136.167 & 121.970 & 129.667 & 116.147 & $(5.822)$ & $-4,77 \%$ \\
\hline $\begin{array}{l}\text { Despesas comerciais } \\
\text { Despesas administrativas + Honorários } \\
\text { dos administradores }\end{array}$ & $\begin{array}{l}(39.273) \\
(54.832)\end{array}$ & $\begin{array}{l}(35.178) \\
(49.115)\end{array}$ & $\begin{array}{l}(40.987) \\
(57.059)\end{array}$ & $\begin{array}{l}\mathbf{( 3 6 . 7 1 4 )} \\
(51.110)\end{array}$ & $\begin{array}{l}(1.535) \\
(1.995)\end{array}$ & $\begin{array}{l}4,36 \% \\
4,06 \%\end{array}$ \\
\hline Despesas financeiras (líquidas) & $(9.737)$ & (8.722) & 30.342 & 27.178 & 35.900 & $-411,62 \%$ \\
\hline Outras despesas (receitas) operacionais & $(2.943)$ & $(2.636)$ & $(1.949)$ & $(1.746)$ & 890 & $-33,78 \%$ \\
\hline Lucro operacional & 29.382 & 28.955 & 60.014 & 55.503 & 26.548 & $91,69 \%$ \\
\hline Resultado não operacional & $(7.565)$ & $(6.776)$ & $(7.396)$ & $(6.625)$ & 151 & $-2,23 \%$ \\
\hline Lucro antes do IR e Contribuição Social & 21.817 & 22.178 & 52.618 & 48.878 & 26.699 & $120,38 \%$ \\
\hline IR e Contribuição Social & $(4.170)$ & (3.735) & $(17.480)$ & $(15.657)$ & $(11.922)$ & $319,18 \%$ \\
\hline Lucro antes participação minoritários & 17.647 & 18.443 & 35.138 & 33.220 & 14.777 & $80,12 \%$ \\
\hline Participação de minoritários & 262 & 235 & & & - & \\
\hline Lucro (Prejuízo) Líquido do Exercício & 17.909 & 18.443 & 35.138 & 33.220 & 14.777 & $80,12 \%$ \\
\hline
\end{tabular}

Fonte: Jornal do Comércio, 19.02.98.

Taxa de câmbio divulgada pelo Banco Central do Brasil para 31.12.1997: US\$1,00 = $\mathbf{R} \$ \quad \mathbf{1 , 1 1 6 4}$ 
Tabela 7 - Conciliação do Lucro Líquido e do Patrimônio Líquido em 1997

Valores em $\mathrm{R} \$$ mil

\begin{tabular}{rr}
\multicolumn{1}{c}{$\begin{array}{c}\text { Lucro } \\
\text { Líquido }\end{array}$} & $\begin{array}{l}\text { Patrimônio } \\
\text { Líquido }\end{array}$ \\
\hline $\mathbf{1 7 . 9 0 9}$ & $\mathbf{2 . 2 8 5 . 2 6 9}$ \\
& \\
4.873 & 10.595 \\
193.489 & 451.437 \\
$(173.358)$ & - \\
$(34)$ & $(99)$ \\
$(7.741)$ & $(92.019)$ \\
\hline $\mathbf{3 5 . 1 3 8}$ & $\mathbf{2 . 6 5 5 . 1 8 3}$ \\
\hline
\end{tabular}

Fonte: Jornal do Comércio, 19.02.98.

(*) O valor de $\mathrm{R} \$ 92.019$ mil, corresponde ao decréscimo na conta Créditos Tributários no Ativo ( $\mathrm{R} \$ 37.456$ mil) e ao acréscimo na conta Imposto de Renda e Contribuição Social Diferidos no Passivo Exigível a Longo Prazo (R \$ 54.563 mil). 
Tabela 8 - ARACRUZ CELULOSE S. A.

Balanço Patrimonial Consolidado em US GAAP em 31 de Dezembro de 1997

\begin{tabular}{|c|c|c|c|c|}
\hline \multicolumn{2}{|r|}{ CONTAS } & \multirow{2}{*}{$\begin{array}{c}\text { (A) } \\
\text { Moeda } \\
\text { Constante } \\
\text { US\$ mil }\end{array}$} & \multirow{2}{*}{\begin{tabular}{|c|} 
(B) \\
US GAAP \\
publicado \\
em US\$ mil \\
\end{tabular}} & \multirow[b]{2}{*}{$\begin{array}{l}\text { Variação \% } \\
(B / A-1)\end{array}$} \\
\hline $\begin{array}{c}\text { BRASIL } \\
\text { Moeda Constante }\end{array}$ & US GAAP & & & \\
\hline ATIVO & ASSETS & & & \\
\hline $\begin{array}{l}\text { Disponível + Aplicações } \\
\text { Financeiras }\end{array}$ & $\begin{array}{l}\text { Cash and cash equivalents }+ \text { Bank deposits, as } \\
\text { a compensating balance (current) }\end{array}$ & 27.736 & 31.495 & $13,55 \%$ \\
\hline $\begin{array}{l}\text { Contas a Receber + Demais } \\
\text { Contas a Receber }\end{array}$ & Accounts receivable & 70.520 & 79.276 & $12,42 \%$ \\
\hline Adiantamentos a Fornecedores & Advances to suppliers & 8.762 & 16.417 & $87,36 \%$ \\
\hline Estoques & Inventories, net & 91.237 & 82.362 & $-9,73 \%$ \\
\hline Títulos e Valores Mobiliários & Debt securities held to maturity & 698.139 & 698.139 & $0,00 \%$ \\
\hline \multirow[t]{2}{*}{ Créditos tributários (circulante) } & Recoverable income and other taxes & 5.458 & 5.457 & $-0,01 \%$ \\
\hline & Deferred income tax, net & & 48.180 & \\
\hline Outros & Prepaid expenses and other current assets & 12.304 & 7.345 & $-40,30 \%$ \\
\hline Créditos Tributários (longo prazo) & Recoverable income tax & 126.346 & 126.299 & $-0,04 \%$ \\
\hline Depósitos Judiciais & Deposits for tax assessments & 40.628 & 40.628 & $0,00 \%$ \\
\hline Outros (realizável a longo prazo) & $\begin{array}{l}\text { Bank deposits, as a compensating balance } \\
\text { (other assets) + Other }\end{array}$ & 7.658 & 8.465 & $10,54 \%$ \\
\hline Investimentos & & 405 & - & \\
\hline Imobilizado & Property, Plant and Equipment, net & 2.782 .736 & 1.978 .656 & $-28,90 \%$ \\
\hline Diferido & & 77.209 & & \\
\hline Total do Ativo & Total Assets & 3.949 .137 & $3.122 .719^{-}$ & \\
\hline PASSIVO & LIABILITIES AND SHAREHOLDER'S EQUITY & & & \\
\hline Circulante & Current Liabilities & 755.835 & 730.821 & $-3,31 \%$ \\
\hline Exigível a Longo Prazo & Long-Term Liabilities & 812.633 & 763.765 & $-6,01 \%$ \\
\hline Participação de Minoritários & Minority Interest & 2.325 & 2.292 & $-1,43 \%$ \\
\hline Patrimônio Líquido & Shareholder's Equity & 2.378 .344 & 1.625 .841 & $-31,64 \%$ \\
\hline Total do Passivo & Total Liabilities and Shareholder's Equity & 3.949 .137 & 3.122 .719 & \\
\hline
\end{tabular}

Fonte: O balanço em US GAAP foi obtido no site: www.aracruz.com.br 


\subsection{Companhia Siderúrgica Nacional - CSN}

Para a Companhia Siderúrgica Nacional foram traduzidas para dólares as demonstrações publicadas de acordo com a legislação societária e em moeda constante, somente para o exercício de 1996, não tendo sido apresentados os anos subseqüentes, pelo fato da empresa não ter publicado suas demonstrações em moeda constante a partir de 1997.

Nas tabelas a seguir encontram-se os valores traduzidos para dólares do balanço patrimonial e da demonstração do resultado de 1997, na qual verificam-se diferenças em dólares e as variações percentuais encontradas na comparação das demonstrações pela legislação societária e em moeda constante.

Dentre os itens que apresentaram variações nas demonstrações em moeda constante, em relação às demonstrações pela legislação societária, destacam-se os seguintes:

- Contas a Receber - o decréscimo de 3,29\% no saldo desta conta, no balanço em moeda constante, refere-se ao ajuste a valor presente que é efetuado com o objetivo de eliminar os juros e a expectativa de inflação futura embutidos no valor das vendas a prazo; 
- Estoques - verificou-se um acréscimo de $12,03 \%$ pela correção monetária dos estoques finais da empresa;

- Adiantamento s/fornecimentos e serviços - este item teve uma variação positiva de $4,89 \%$, representando a correção monetária do período para os estoques ainda não recebidos, para os quais foi feito o adiantamento;

- Ativo Permanente - a correção monetária do Ativo Permanente aumentou em 5,79\% o subgrupo Investimentos, em 9,10\% o Imobilizado e em $6,77 \%$ o Diferido, no balanço em moeda constante;

- Patrimônio Líquido - foram apuradas as variações positivas, relativas à correção monetária, de 9,21\% para "Capital social integralizado", 9,22\% para "Reservas de Reavaliação" e 12,02\% para "Reservas de Lucros";

- Outras (despesas) receitas líquidas - esta conta teve uma variação percentual significativa de $-111,28 \%$, embora em valores absolutos esta variação não seja tão representativa, tendo evoluído de uma despesa de $R \$ 1.516$ mil para uma receita de $R \$$ 171 mil, sem que se possa explicar as causas desta variação, visto que a empresa não informou a composição deste item;

- Receitas e Despesas Financeiras - as receitas financeiras apresentaram uma variação para mais de apenas 0,50\%, enquanto que as despesas financeiras variaram para menos em 14,56\%, em função da eliminação da correção monetária embutida em seus saldos. 
- Lucro líquido do exercício - em face dos ajustes pelos efeitos inflacionários, o lucro do exercício foi reduzido em 28,39\%, conforme revela a conciliação entre os resultados apurados pela legislação societária e pela correção monetária integral na tabela 11 a seguir.

O balanço em US GAAP de 1996 da Companhia Siderúrgica Nacional não estava mais disponível em seu site na Internet, tendo sido solicitado à empresa, sem obtenção de resposta. Assim, utilizou-se para análise apenas a demonstração do resultado de 1996, a qual constava das demonstrações comparativas dos últimos três anos, apresentadas no ano de 1998. No caso do balanço patrimonial a comparação é de apenas dois anos, conforme comentado no Capítulo 2.

Também não foi obtida a reconciliação do patrimônio líquido e do lucro de 1996, de modo que não foi possível evidenciar em termos monetários os efeitos dos ajustes efetuados nas demonstrações contábeis a fim de adequá-las às exigências das normas contábeis norte-americanas (US GAAP).

Na tabela 12, procurou-se comparar os valores da demonstração do resultado em US GAAP, divulgada nos EUA, com os valores da demonstração do resultado em moeda constante, divulgada no Brasil e traduzida para dólares na coluna (B) da tabela 10.

Como é possível observar na tabela 12, quase todos os itens apresentaram variações significativas na comparação da demonstração em US GAAP com a demonstração em moeda constante, com exceção das despesas de vendas, das receitas financeiras e da contribuição social. 
Dentre os itens que apresentaram variações relevantes, merece destaque especial o item despesas gerais e administrativas, que foi superior em 200,27\% na demonstração em US GAAP, e o item despesas/receitas não operacionais líquidas, para o qual não há item correspondente naquela demonstração.

Tal coincidência pode significar que as despesas/receitas não operacionais, no todo ou em parte, foram classificadas como despesas gerais e administrativas, uma vez que os conceitos de resultado operacional e não-operacional, pelas normas contábeis norte-americanas, diferem dos conceitos utilizados nas normas brasileiras, como é o caso das receitas e despesas financeiras, que no Brasil são classificadas como operacionais e nos EUA como não-operacionais.

Outro item com variação significativa foi o resultado da equivalência patrimonial (participação em sociedades controladas), cujo valor apresentado nos EUA foi $62,56 \%$ menor do que o valor apresentado no Brasil. As notas explicativas não apresentam subsídios para explicar tal variação, no entanto, sabe-se que o critério para utilização do método de equivalência patrimonial difere das normas brasileiras para as normas norteamericanas, conforme já comentado no capítulo 2. 

Tabela 9 - Companhia Siderúrgica Nacional

Balanço Patrimonial Consolidado em 31 de Dezembro de 1996

\begin{tabular}{|c|c|c|c|c|c|c|}
\hline ATIVO & $\begin{array}{c}\text { Legislação } \\
\text { Societária em } \\
\mathrm{R} \$ \text { mil }\end{array}$ & $\begin{array}{l}\text { (A) } \\
\text { Legislação } \\
\text { Societária } \\
\text { em US\$ mil }\end{array}$ & $\begin{array}{l}\text { Moeda } \\
\text { Constante } \\
\text { em } R \$ \text { mil }\end{array}$ & \begin{tabular}{|c|} 
(B) \\
Moeda \\
Constante \\
em US\$ mil
\end{tabular} & $\begin{array}{c}\text { Variação } \\
\text { absoluta } \\
(B-A) \\
\text { em US\$ mil }\end{array}$ & $\begin{array}{c}\text { Variação \% } \\
(B / A-1)\end{array}$ \\
\hline \multicolumn{7}{|l|}{ CIRCULANTE } \\
\hline Disponível & 6.579 & 6.330 & 6.579 & 6.330 & - & $0,00 \%$ \\
\hline Títulos e Valores Mobiliários & 682.950 & 657.062 & 682.950 & 657.062 & - & $0,00 \%$ \\
\hline Contas a Receber & 368.546 & 354.576 & 356.432 & 342.921 & $(11.655)$ & $-3,29 \%$ \\
\hline Provisão para Devedores Duvidosos & $(52.661)$ & $(50.665)$ & $(52.661)$ & $(50.665)$ & - & $0,00 \%$ \\
\hline Estoques & 538.851 & 518.425 & 603.657 & 580.774 & 62.349 & $12,03 \%$ \\
\hline Adiantamento s/fornecimentos e serviços & 195.882 & 188.457 & 205.468 & 197.679 & 9.223 & $4,89 \%$ \\
\hline Títulos e Valores a Receber & 76.399 & 73.503 & 76.399 & 73.503 & - & $0,00 \%$ \\
\hline Imposto de Renda a Compensar & 95.070 & 91.466 & 95.070 & 91.466 & - & $0,00 \%$ \\
\hline Outros & 99.146 & 95.388 & 99.146 & 95.388 & - & $0,00 \%$ \\
\hline & 2.010 .762 & 1.934 .541 & 2.073 .040 & 1.994 .458 & 59.917 & $3,10 \%$ \\
\hline \multicolumn{7}{|l|}{ REALIZÁVEL A LONGO PRAZO } \\
\hline Empréstimos - ELETROBRÁS & 40.443 & 38.910 & 40.443 & 38.910 & - & $0,00 \%$ \\
\hline Imposto de Renda a Compensar & 64.104 & 61.674 & 64.104 & 61.674 & - & $0,00 \%$ \\
\hline $\begin{array}{l}\text { Contas a Receber - empresas ligadas } \\
\text { Depósitos Judiciais, inclui } \mathrm{R} \$ 77.103 \text { mil } \\
\text { de contribuição social }\end{array}$ & $\begin{array}{r}45.023 \\
109.177\end{array}$ & $\begin{array}{r}43.316 \\
105.038\end{array}$ & $\begin{array}{r}45.023 \\
109.177\end{array}$ & $\begin{array}{r}43.316 \\
105.038\end{array}$ & - & $\begin{array}{l}0,00 \% \\
0,00 \%\end{array}$ \\
\hline Títulos e Valores a Receber & 56.442 & 54.302 & 56.442 & 54.302 & - & $0,00 \%$ \\
\hline \multirow{2}{*}{ Outros } & 35.290 & 33.952 & 35.290 & 33.952 & - & $0,00 \%$ \\
\hline & \multicolumn{6}{|c|}{ PERMANENTE } \\
\hline Investimentos & 385.420 & 370.810 & 407.745 & 392.289 & 21.479 & $5,79 \%$ \\
\hline Imobilizado & 3.747 .696 & 3.605 .634 & 4.088 .578 & 3.933 .594 & 327.960 & $9,10 \%$ \\
\hline \multirow[b]{3}{*}{ Total do Ativo } & 17.462 & 16.800 & 18.644 & 17.937 & 1.137 & $6,77 \%$ \\
\hline & 4.150 .578 & 3.993 .244 & 4.514 .967 & 4.343 .820 & 350.576 & $8,78 \%$ \\
\hline & 6.511 .819 & 6.264 .979 & 6.938 .486 & 6.675 .472 & 410.494 & $6,55 \%$ \\
\hline
\end{tabular}




\begin{tabular}{|c|c|c|c|c|c|c|}
\hline PASSIVO & $\begin{array}{c}\text { Legislação } \\
\text { Societária em } \\
\mathrm{R} \$ \text { mil }\end{array}$ & $\begin{array}{c}\text { (A) } \\
\text { Legislação } \\
\text { Societária } \\
\text { em US\$ mil }\end{array}$ & $\begin{array}{l}\text { Moeda } \\
\text { Constante } \\
\text { em } R \$ \text { mil }\end{array}$ & \begin{tabular}{|c|} 
(B) \\
Moeda \\
Constante \\
em US\$ mil
\end{tabular} & \begin{tabular}{|c|} 
Variação \\
absoluta \\
$(B-A)$ \\
em US\$ mil
\end{tabular} & $\begin{array}{c}\text { Variação \% } \\
(B / A-1)\end{array}$ \\
\hline \multicolumn{7}{|l|}{ CIRCULANTE } \\
\hline Empréstimos e financiamentos & 791.408 & 761.409 & 791.408 & 761.409 & - & $0,00 \%$ \\
\hline Fornecedores & 81.570 & 78.478 & 81.488 & 78.399 & (79) & $-0,10 \%$ \\
\hline Contribuição social s/ lucro & 1.112 & 1.070 & 1.112 & 1.070 & - & $0,00 \%$ \\
\hline Salários e contribuições sociais & 14.805 & 14.244 & 14.805 & 14.244 & - & $0,00 \%$ \\
\hline Tributos a Recolher & 6.299 & 6.060 & 6.299 & 6.060 & - & $0,00 \%$ \\
\hline Tributos e obrigações parceladas & 48.284 & 46.454 & 48.284 & 46.454 & - & $0,00 \%$ \\
\hline Dividendos propostos e a pagar & 87.480 & 84.164 & 87.480 & 84.164 & - & $0,00 \%$ \\
\hline \multirow[t]{2}{*}{ Outros } & 85.886 & 82.630 & 85.871 & 82.616 & $(14)$ & $-0,02 \%$ \\
\hline & 1.116 .844 & 1.074 .508 & 1.116 .747 & 1.074 .415 & (93) & $-0,01 \%$ \\
\hline \multicolumn{7}{|l|}{ EXIGÍVEL A LONGO PRAZO } \\
\hline Empréstimos e financiamentos & 875.316 & 842.136 & 875.316 & 842.136 & - & $0,00 \%$ \\
\hline Tributos e obrigações parceladas & 74.839 & 72.002 & 74.839 & 72.002 & - & $0,00 \%$ \\
\hline Contribuição social em juízo & 74.284 & 71.468 & 74.284 & 71.468 & - & $0,00 \%$ \\
\hline \multirow[t]{2}{*}{ Outros } & 67.020 & 64.480 & 67.020 & 64.480 & - & $0,00 \%$ \\
\hline & 1.091 .459 & 1.050 .086 & 1.091 .459 & 1.050 .086 & - & $0,00 \%$ \\
\hline \multicolumn{7}{|l|}{ PATRIMÔNIO LÍQUIDO } \\
\hline Capital social integralizado & 1.680 .947 & 1.617 .228 & 1.835 .715 & 1.766 .129 & 148.901 & $9,21 \%$ \\
\hline Reservas de reavaliação & 1.543 .224 & 1.484 .726 & 1.685 .449 & 1.621 .560 & 136.834 & $9,22 \%$ \\
\hline Reservas de lucros & $\frac{1.079 .345}{4.303 .516}$ & $\frac{1.038 .431}{4.140 .385}$ & $\frac{1.209 .116}{4.730 .280}$ & \begin{tabular}{|l|}
1.163 .283 \\
4.550 .972 \\
\end{tabular} & $\begin{array}{l}124.852 \\
410.587 \\
\end{array}$ & $\begin{array}{r}12,02 \% \\
9,92 \%\end{array}$ \\
\hline Total do Passivo & 6.511 .819 & 6.264 .979 & 6.938 .486 & 6.675.472 & 410.494 & $6,55 \%$ \\
\hline
\end{tabular}

Fonte: Jornal O Globo, 06.03.97.

Taxa de câmbio divulgada pelo Banco Central do Brasil para 31.12.1996: US\$1,00 = R $\$ \quad \mathbf{1 , 0 3 9 4}$ 
Tabela 10 - COMPANHIA SIDERÚRGICA NACIONAL

Demonstração do Resultado para o Exercício findo em 31 de Dezembro de 1996

\begin{tabular}{|c|c|c|c|c|c|c|}
\hline CONTAS & $\begin{array}{c}\text { Legislação } \\
\text { Societária em } \\
\mathrm{R} \$ \text { mil } \\
\end{array}$ & $\begin{array}{c}\text { (A) } \\
\text { Legislação } \\
\text { Societária } \\
\text { em US } \$ \text { mil }\end{array}$ & $\begin{array}{c}\text { Moeda } \\
\text { Constante } \\
\text { em } R \$ \text { mil }\end{array}$ & $\begin{array}{c}\text { (B) } \\
\text { Moeda } \\
\text { Constante } \\
\text { em US\$ mil }\end{array}$ & $\begin{array}{c}\text { Variação } \\
\text { absoluta } \\
(B-A) \\
\text { em US\$ mil }\end{array}$ & $\begin{array}{c}\text { Variação \% } \\
(B / A-1)\end{array}$ \\
\hline Receita líquida de vendas & 2.223 .384 & 2.139 .103 & 2.271 .557 & 2.185 .450 & 46.347 & $2,17 \%$ \\
\hline Custo dos produtos vendidos & $(1.644 .528)$ & $(1.582 .190)$ & $(1.802 .349)$ & $(1.734 .028)$ & $(151.839)$ & $9,60 \%$ \\
\hline $\begin{array}{l}\text { Lucro bruto } \\
\text { (Despesas) Receitas Operacionais }\end{array}$ & 578.856 & 556.914 & 469.208 & 451.422 & $(105.492)$ & $-18,94 \%$ \\
\hline Despesas com vendas & (228.937) & (220.259) & $(233.666)$ & (224.809) & $(4.550)$ & $2,07 \%$ \\
\hline $\begin{array}{l}\text { Despesas gerais e administrativas (inclui } \\
\text { honorários da diretoria e conselho) }\end{array}$ & (77.325) & (74.394) & (78.578) & (75.599) & $(1.206)$ & $1,62 \%$ \\
\hline Depreciação e amortização & (19.871) & (19.118) & $(20.693)$ & (19.909) & (791) & $4,14 \%$ \\
\hline Outras (despesas) receitas líquidas & $(1.516)$ & $(1.459)$ & 171 & 165 & 1.623 & $-111,28 \%$ \\
\hline Despesas financeiras & $(153.524)$ & (147.704) & $(131.173)$ & (126.201) & 21.504 & $-14,56 \%$ \\
\hline Receitas financeiras & 161.013 & 154.910 & 160.205 & 154.132 & (777) & $-0,50 \%$ \\
\hline Participação em Sociedades Controladas & (28.290) & (27.218) & $(27.763)$ & (26.711) & 507 & $-1,86 \%$ \\
\hline Efeitos inflacionários (líquidos) & (28.481) & (27.401) & - & - & 27.401 & \\
\hline $\begin{array}{l}\text { (Despesas) Receitas não operacionais, } \\
\text { líquidas }\end{array}$ & $(80.660)$ & $(77.602)$ & $(87.995)$ & $(84.659)$ & $(7.057)$ & $9,09 \%$ \\
\hline Lucro antes do IR e Contribuição Social & 121.265 & 116.668 & 49.716 & 47.831 & $(68.837)$ & $-59,00 \%$ \\
\hline Contribuição Social & $(25.786)$ & $(24.809)$ & $(26.534)$ & $(25.528)$ & (720) & $2,90 \%$ \\
\hline Crédito fiscal do imposto de renda & 159.174 & 153.140 & 159.174 & 153.140 & & $0,00 \%$ \\
\hline Lucro Líquido do Exercício & 254.653 & 245.000 & 182.356 & 175.444 & $(69.556)$ & $-28,39 \%$ \\
\hline
\end{tabular}

Fonte: Jornal O Globo, 06.03.97.

Taxa de câmbio divulgada pelo Banco Central do Brasil para 31.12.1996: US\$1,00 = R $\mathbf{\$} \quad \mathbf{1 , 0 3 9 4}$ 
Tabela 11 - Conciliação do Lucro Líquido e do Patrimônio Líquido em 1996

\begin{tabular}{cc}
\multicolumn{2}{c}{ Valores em $\mathrm{R} \$$ mil } \\
\hline $\begin{array}{c}\text { Lucro } \\
\text { Líquido }\end{array}$ & $\begin{array}{c}\text { Patrimônio } \\
\text { Líquido }\end{array}$ \\
\hline
\end{tabular}

\section{Pela legislação societária.}

\section{$254.653 \quad 4.303 .516$}

Reversão de ajuste do exercício anterior.

- $\quad 111.756$

Ajuste a valor presente de créditos e obrigações: Contas a Receber.

$1.455 \quad 1.455$

Contas a Pagar...

Correção monetária:

Ativo permanente e patrimônio líquido..............

Estoques.

Adiantamentos sobre fornecimentos e serviços Correção integral.

\begin{tabular}{ll}
182.356 & 4.730 .280 \\
\hline
\end{tabular}

Fonte: Jornal O Globo, 06.03.97. 
Tabela 12 - COMPANHIA SIDERÚRGICA NACIONAL

Demonstração do Resultado em US GAAP para o Exercício findo em 31 de Dezembro de 1996

\begin{tabular}{|c|c|c|c|c|}
\hline \multicolumn{2}{|c|}{ CONTAS } & \multirow{2}{*}{$\begin{array}{c}\text { (A) } \\
\text { Moeda } \\
\text { Constante } \\
\text { em US\$ mil }\end{array}$} & \multirow{2}{*}{\begin{tabular}{|c|} 
(B) \\
US GAAP \\
publicado em \\
US\$ mil
\end{tabular}} & \multirow[b]{2}{*}{$\begin{array}{c}\text { Variação \% } \\
\text { (B/A -1) }\end{array}$} \\
\hline $\begin{array}{l}\text { BRASIL } \\
\text { Moeda Constante }\end{array}$ & US GAAP & & & \\
\hline Receita líquida de vendas & Net operating revenues & 2.185 .450 & 2.416 .000 & $10,55 \%$ \\
\hline Custo dos produtos vendidos & Cost of products sold & $(1.734 .028)$ & $(1.618 .000)$ & $-6,69 \%$ \\
\hline Lucro bruto & Gross profit & 451.422 & 798.000 & $76,77 \%$ \\
\hline (Despesas) Receitas Operacionais & Operating expenses & & & \\
\hline Despesas com vendas & Selling & (224.809) & $(219.000)$ & $-2,58 \%$ \\
\hline $\begin{array}{l}\text { Despesas gerais e administrativas (inclui } \\
\text { honorários da diretoria e conselho) }\end{array}$ & General and administrative & $(75.599)$ & $(227.000)$ & $200,27 \%$ \\
\hline \multirow[t]{2}{*}{$\begin{array}{l}\text { Depreciação e amortização + Outras } \\
\text { (despesas) receitas líquidas }\end{array}$} & Others & \multirow[t]{2}{*}{$(19.744)$} & $(33.000)$ & $67,14 \%$ \\
\hline & Operating income & & 319.000 & \\
\hline Despesas financeiras & Financial expenses & $(126.201)$ & (115.000) & $-8,88 \%$ \\
\hline Receitas financeiras & Financial income & 154.132 & 152.000 & $-1,38 \%$ \\
\hline \multirow[t]{2}{*}{ Participação em Sociedades Controladas } & Equity in results of affiliated companies & $(26.711)$ & $(10.000)$ & $-62,56 \%$ \\
\hline & Translation loss, net + Others & & $(30.000)$ & \\
\hline $\begin{array}{l}\text { (Despesas) Receitas não operacionais, } \\
\text { líquidas }\end{array}$ & & $(84.659)$ & & \\
\hline Lucro antes do IR e Contribuição Social & & 47.831 & & $-100,00 \%$ \\
\hline Contribuição Social & Income taxes - current & $(25.528)$ & $(27.000)$ & $5,77 \%$ \\
\hline Crédito fiscal do imposto de renda & Income taxes - deferred & 153.140 & $(77.000)$ & $-150,28 \%$ \\
\hline Lucro Líquido do Exercício & Net Income for the year & 175.444 & 212.000 & $20,84 \%$ \\
\hline
\end{tabular}

Fonte: A demonstração do resultado em US GAAP foi obtida no site: www.csn.com.br 


\subsection{COPENE - Petroquímica do Nordeste S.A.}

Foram traduzidas para dólares e comparadas as demonstrações contábeis publicadas no Brasil, de acordo com a legislação societária e em moeda de capacidade aquisitiva constante, dos exercícios de 1997, 1998 e 1999, a fim de evidenciar os efeitos da inflação neste período.

Em seguida, foram comparados, nos mesmos exercícios, os balanços traduzidos para dólares com os balanços em US GAAP publicados nos EUA, com o objetivo de comparar os saldos dos dois balanços e apontar eventuais diferenças entre as práticas contábeis brasileiras e norteamericanas.

O exercício de 1996 não foi analisado pelo fato da empresa não ter publicado suas demonstrações em US GAAP neste ano, em face de que somente começou a operar na Bolsa de Valores de Nova lorque a partir de 1998, quando apresentou apenas os balanços comparativos dos últimos dois anos (1997 e 1998).

Nas tabelas a seguir encontram-se os valores traduzidos para dólares do balanço patrimonial e da demonstração do resultado resumidos dos três exercícios, na qual verificam-se diferenças em valores absolutos e relativos encontradas na comparação das demonstrações pela legislação societária e em moeda constante. 
Dentre os itens que apresentaram variações nas demonstrações em moeda constante, em relação às demonstrações pela legislação societária, destacam-se os seguintes no ano de 1997:

- Circulante - a variação para mais de 3,53\% refere-se aos estoques, que aumentaram com a correção monetária de $R \$$ 109.862 mil para $\mathrm{R} \$ 128.885$ mil;

- Realizável a longo prazo - o acréscimo em 0,81\% refere-se ao item "Outras”, não especificado pela empresa;

- Permanente - como se observa na tabela 13 , os subgrupos do ativo permanente tiveram as seguintes variação pela correção monetária do período: investimentos $20,01 \%$, imobilizado $16,84 \%$ e diferido $11,23 \%$;

- Exigível a longo prazo - a variação de 0,24\% refere-se aos itens "Sociedades controladas, coligadas e interligadas", que aumentou de $R \$ 231$ mil para $R \$ 989$ mil, e "Outras", que teve um aumento de $R \$ 30.411$ mil para $R \$ 31.755$ mil, também sem especificação;

- Resultado de exercícios futuros - este item teve uma expressiva variação para mais de $11,49 \%$ pela correção monetária do período que, segundo a nota explicativa $n^{0} 25$, representa o deságio apurado na aquisição de Certificados de Participações em Reflorestamento - CPRs, da controlada em conjunto NORCELL S.A.;

- Participação de terceiros - a correção monetária deste item representou um acréscimo de $16,11 \%$ em seu saldo; 
- Patrimônio líquido - o acréscimo de $20,06 \%$ está evidenciado na tabela 15, que apresenta a conciliação entre o patrimônio líquido das demonstrações pela legislação societária e em moeda constante;

- Receitas (despesas) não operacionais - este item é composto de resultado na alienação de ativo permanente, amortização de ágio, provisão para provável perda com investimentos e outras receitas/despesas líquidas, na demonstração de resultado pela legislação societária, no entanto, não é possível explicar por item a variação total de $36,89 \%$, de $R$ \$ 15.431 mil para $R \$ 21.124$ mil, visto que a empresa não fez a abertura do valor de $R \$ 21.124$ mil na demonstração em moeda constante;

- Lucro líquido do exercício - o lucro do período teve uma pequena redução de $1,23 \%$ em função dos efeitos da correção monetária do período, conforme se observa na tabela 15 , que apresenta a conciliação entre o lucro líquido apurado pela legislação societária e em moeda constante.

Nos exercícios de 1998 e 1999 a empresa apresentou apenas demonstrações resumidas em moeda constante, de modo que não foi possível especificar que itens dentro dos grupos sofreram variações. Supõese que as variações em 1998 e 1999 ocorreram nos mesmos itens que em 1997, até porque os acréscimos nos grupos se mantiveram na mesma proporção nos três exercícios, embora, a maioria dos grupos, tenha apresentado uma tendência crescente, conforme se comenta a seguir: 
- Circulante - apresentou a variação para mais de 3,53\% em 1997, 4,01\% em 1998 e $2,82 \%$ em 1999;

- Realizável a longo prazo - o acréscimo em 1997 foi de 0,81\%, em 1998 1,49\%, sendo que em 1999 este grupo não apresentou variação;

- Investimentos - o subgrupo investimentos teve os seguintes acréscimos em cada exercício: 20,01\% em 1997, 23,90\% em 1998 e $39,76 \%$ em 1999 ;

- Imobilizado - este subgrupo aumentou em 16,84\% em 1997, $18,01 \%$ em 1998 e $40,60 \%$ em 1999;

- Diferido - o diferido teve um acréscimo de $11,23 \%$ em 1997, 8,62\% em 1998 e 19\% em 1999;

- Exigível a longo prazo - este grupo, que teve a variação de $0,24 \%$ em 1997, praticamente não variou nos exercícios de 1998 e 1999;

- Resultado de exercícios futuros - este item teve uma variação crescente, passando de 11,49\% em 1997 para 34,44\% em 1998 e para $42,89 \%$ em 1999 ;

- Participação de terceiros - a correção monetária deste item representou um acréscimo de 16,11\% em 1997, 13,93\% em 1998 e 35,26\% em 1999, também revelando uma tendência crescente;

- Patrimônio líquido - os acréscimos de 21,65\% em 1998 e 42,59\% em 1999 estão evidenciados nas tabelas 19 e 23 , respectivamente, as quais apresentam a conciliação entre o 
patrimônio líquido das demonstrações pela legislação societária e em moeda constante;

- Despesas não operacionais - este item, que apresentou a mesma composição nos três anos (resultado na alienação de ativo permanente, amortização de ágio, provisão para provável perda com investimentos e outras receitas/despesas líquidas), teve um acréscimo de 36,89\% em 1997, 21,98\% em 1998 e de $113,44 \%$ em 1999, na demonstração de resultado em moeda constante;

- Lucro (prejuízo) líquido do exercício - o prejuízo de $\mathrm{R} \$ 4.513$ mil em 1997 foi aumentado para $\mathrm{R} \$ 40.209$ mil, apresentando uma variação de 790,96\% pelos efeitos da correção monetária do período, sendo que em 1999 o lucro apurado pela legislação societária teve uma redução de 6,94\% na demonstração de resultado em moeda constante. As conciliações entre o lucro líquido apurado pela legislação societária e em moeda constante dos anos de 1998 e 1999 são apresentadas nas tabelas 19 e 23, respectivamente.

Com relação aos balanços em US GAAP, não foi possível quantificar os efeitos das diferenças entre as práticas contábeis brasileiras e norteamericanas, em função de que a empresa não apresentou a reconciliação entre o patrimônio líquido do balanço em US GAAP e o patrimônio líquido do balanço publicado no Brasil.

Nas tabelas 16, 20 e 24, procurou-se comparar os saldos do balanço em US GAAP, publicado nos EUA, com os saldo do balanço publicado no 
Brasil, sendo que, no ano de 1997 utilizou-se o balanço em moeda constante para tal comparação (tabela 16) e nos anos de 1998 e 1999 foram usados os balanços elaborados de acordo com a legislação societária brasileira (tabelas 20 e 24), visto que, a partir de 1998, os balanços em US GAAP passaram a não mais considerar os efeitos da inflação, conforme já comentado anteriormente no capítulo 1.

A partir da tentativa de comparar os saldos dos balanços dos três exercícios, nas tabelas 16, 20 e 24, observa-se, em todos os exercícios, a coincidência dos saldos de Títulos a receber entre os dois balanços, bem como a similaridade dos saldos de Contas a Receber e Depósitos Judiciais, o que demonstra o igual tratamento contábil dado a esses itens pela empresa no balanço em US GAAP.

É importante destacar os itens a seguir, que revelaram algumas das principais distorções causadas pelas diferenças de práticas contábeis no Brasil e EUA nos três exercícios analisados:

- Disponibilidades - no item "cash and cash equivalent" foram apresentados valores bem superiores àqueles constantes dos itens Caixa, Bancos e Aplicações financeiras, demonstrando que o conceito de disponibilidade difere de um país para o outro pois, enquanto no Brasil são classificados como disponíveis os valores com liquidez imediata, nos EUA são considerados também os investimentos de curto prazo resgatáveis em até 90 dias, conforme evidenciado nas notas explicativas do balanço em US GAAP, que 
também informam que os referidos investimentos foram estimados pelo seu valor justo (fair value);

- Pagamento antecipado de custos de plano de pensão - o item "Prepaid pension costs" não tem correspondente no balanço publicado no Brasil, ao menos de forma destacada, sabe-se, no entanto, que o tratamento contábil dado no Brasil a tais custos, até 2000, era diferente do tratamento dado pelos US GAAP, conforme já discutido no capítulo 2;

- Investimentos em operações descontinuadas (Investments on discontinued operations) - este item não encontra correspondente no balanço de 1997 publicado no Brasil, tendo sido relacionado ao item "Investimentos a alienar" do realizável a longo prazo em 1998 pela similaridade dos valores apresentados. Nas notas explicativas do balanço em US GAAP a empresa informa que este item referese ao contrato de venda dos ativos da subsidiária CEMAN Central de Manutenção Ltda.;

- Investimentos - os valores apresentados nos dois balanços, segregados em "Sociedade coligadas" e "Outros" apresentam variações relevantes, sendo que em todos os exercícios os valores lançados como investimentos em sociedades coligadas no balanço em US GAAP é superior ao lançado no Brasil, ocorrendo a situação inversa no caso de outros investimentos, o que revela as diferenças nos critérios de classificação de empresas como coligadas pelas normas norte-americanas, já mencionadas no 
capítulo 2. A empresa comenta nas notas explicativas do balanço em US GAAP que são classificados como investimentos em companhias ligadas (affiliated companies) os casos em que pode exercer influência significativa sobre as políticas operacionais e financeiras;

- Sociedades controladas, coligadas e interligadas - as diferenças comentadas no item anterior ficam também evidentes quando comparado o item "Sociedades controladas, coligadas e interligadas" do passivo exigível a longo prazo, que apresenta nos balanços em US GAAP valores superiores àqueles apresentados nos balanços publicados no Brasil;

- Resultado de exercícios futuros - este grupo, que no balanço brasileiro representa o deságio apurado na aquisição de Certificados de Participações em Reflorestamento - CPRs, da controlada em conjunto NORCELL S.A., não apresenta correspondente no balanço em US GAAP, não tendo sido evidenciado pela empresa em notas explicativas a forma como esse deságio foi contabilizado nas demonstrações apresentadas nos EUA. 

Tabela 13 - COPENE - Petroquímica do Nordeste S.A.

Balanço Patrimonial Consolidado em 31 de Dezembro de 1997

\begin{tabular}{|c|c|c|c|c|c|c|}
\hline CONTAS & $\begin{array}{c}\text { Legislação } \\
\text { Societária em } \\
\mathrm{R} \$ \text { mil }\end{array}$ & $\begin{array}{c}(A) \\
\text { Legislação } \\
\text { Societária em } \\
\text { US\$ mil }\end{array}$ & $\begin{array}{c}\text { Moeda } \\
\text { Constante } \\
\text { em } R \$ \text { mil }\end{array}$ & $\begin{array}{c}\text { (B) } \\
\text { Moeda } \\
\text { Constante } \\
\text { em US\$ mil }\end{array}$ & $\begin{array}{l}\text { Variação } \\
\text { absoluta } \\
\text { (B - A) em } \\
\text { US\$ mil }\end{array}$ & $\begin{array}{c}\text { Variação \% } \\
(B / A-1)\end{array}$ \\
\hline \multicolumn{7}{|l|}{ ATIVO } \\
\hline Circulante & 538.562 & 482.410 & 557.579 & 499.444 & 17.034 & $3,53 \%$ \\
\hline Realizável a Longo Prazo & 222.031 & 198.881 & 223.834 & 200.496 & 1.615 & $0,81 \%$ \\
\hline Investimentos & 141.499 & 126.746 & 169.815 & 152.109 & 25.364 & $20,01 \%$ \\
\hline Imobilizado & 2.888 .653 & 2.587.471 & 3.375 .232 & 3.023.318 & 435.846 & $16,84 \%$ \\
\hline Diferido & 273.382 & 244.878 & 304.071 & 272.367 & 27.489 & $11,23 \%$ \\
\hline Total do Permanente & 3.303 .534 & 2.959 .095 & 3.849 .118 & 3.447 .795 & 488.699 & $16,52 \%$ \\
\hline Total do Ativo & 4.064 .127 & 3.640 .386 & 4.630 .531 & 4.147.735 & 507.349 & $13,94 \%$ \\
\hline \multicolumn{7}{|l|}{ PASSIVO } \\
\hline Circulante & 370.667 & 332.020 & 370.648 & 332.003 & (17) & $-0,01 \%$ \\
\hline Exigível a Longo Prazo & 863.707 & 773.654 & 865.809 & 775.537 & 1.883 & $0,24 \%$ \\
\hline Resultado Exercícios Futuros & 22.541 & 20.191 & 25.132 & 22.512 & 2.321 & $11,49 \%$ \\
\hline Participação de Terceiros & 33.568 & 30.068 & 38.977 & 34.913 & 4.845 & $16,11 \%$ \\
\hline Patrimônio Líquido & 2.773 .644 & 2.484 .454 & 3.329 .965 & 2.982.771 & 498.317 & $20,06 \%$ \\
\hline Total do Passivo & 4.064 .127 & 3.640 .386 & 4.630 .531 & 4.147.735 & 507.349 & $13,94 \%$ \\
\hline
\end{tabular}

Fonte: Jornal A Tarde, 29.01.98

Taxa de câmbio divulgada pelo Banco Central do Brasil para 31.12.1997: $\quad$ US\$1,00 $=\mathbf{R} \$ \mathbf{1 , 1 1 6 4}$ 
Tabela 14 - COPENE - Petroquímica do Nordeste S.A.

Demonstração do Resultado para o Exercício findo em 31 de Dezembro de 1997

\begin{tabular}{|c|c|c|c|c|c|c|}
\hline CONTAS & $\begin{array}{l}\text { Legislação } \\
\text { Societária em } \\
\text { R\$ mil }\end{array}$ & \begin{tabular}{|c|} 
(A) \\
Legislação \\
Societária em \\
US\$ mil \\
\end{tabular} & $\begin{array}{c}\text { Moeda } \\
\text { Constante em } \\
\mathrm{R} \$ \text { mil } \\
\end{array}$ & $\begin{array}{c}\text { (B) } \\
\text { Moeda } \\
\text { Constante } \\
\text { em US\$ mil }\end{array}$ & $\begin{array}{l}\text { Variação } \\
\text { absoluta } \\
\text { (B - A) em } \\
\text { US\$ mil }\end{array}$ & $\begin{array}{c}\text { Variação \% } \\
(B / A-1)\end{array}$ \\
\hline Receita Operacional Líquida & 1.513 .761 & 1.355 .931 & 1.555 .275 & 1.393 .116 & 37.186 & $2,74 \%$ \\
\hline Lucro Bruto & 281.871 & 252.482 & 262.183 & 234.847 & $(17.635)$ & $-6,98 \%$ \\
\hline Lucro Operacional & 94.567 & 84.707 & 100.701 & 90.202 & 5.494 & $6,49 \%$ \\
\hline Receitas (Despesas) Não Operacionais & $(15.431)$ & $(13.822)$ & $(21.124)$ & $(18.922)$ & (5.099) & $36,89 \%$ \\
\hline Provisão para Imposto de Renda + Participações (líquido) & $(13.431)$ & (12.031) & $(14.679)$ & (13.149) & $(1.118)$ & $9,29 \%$ \\
\hline Lucro (Prejuízo) Líquido do Exercício & 65.705 & 58.854 & 64.898 & 58.131 & (723) & $-1,23 \%$ \\
\hline
\end{tabular}

Fonte: Jornal A Tarde, 29.01.98.

Taxa de câmbio divulgada pelo Banco Central do Brasil para 31.12.1997: US\$1,00 = R \$ 1,1164 
Tabela 15 - Conciliação do Lucro Líquido e do Patrimônio Líquido em 1997

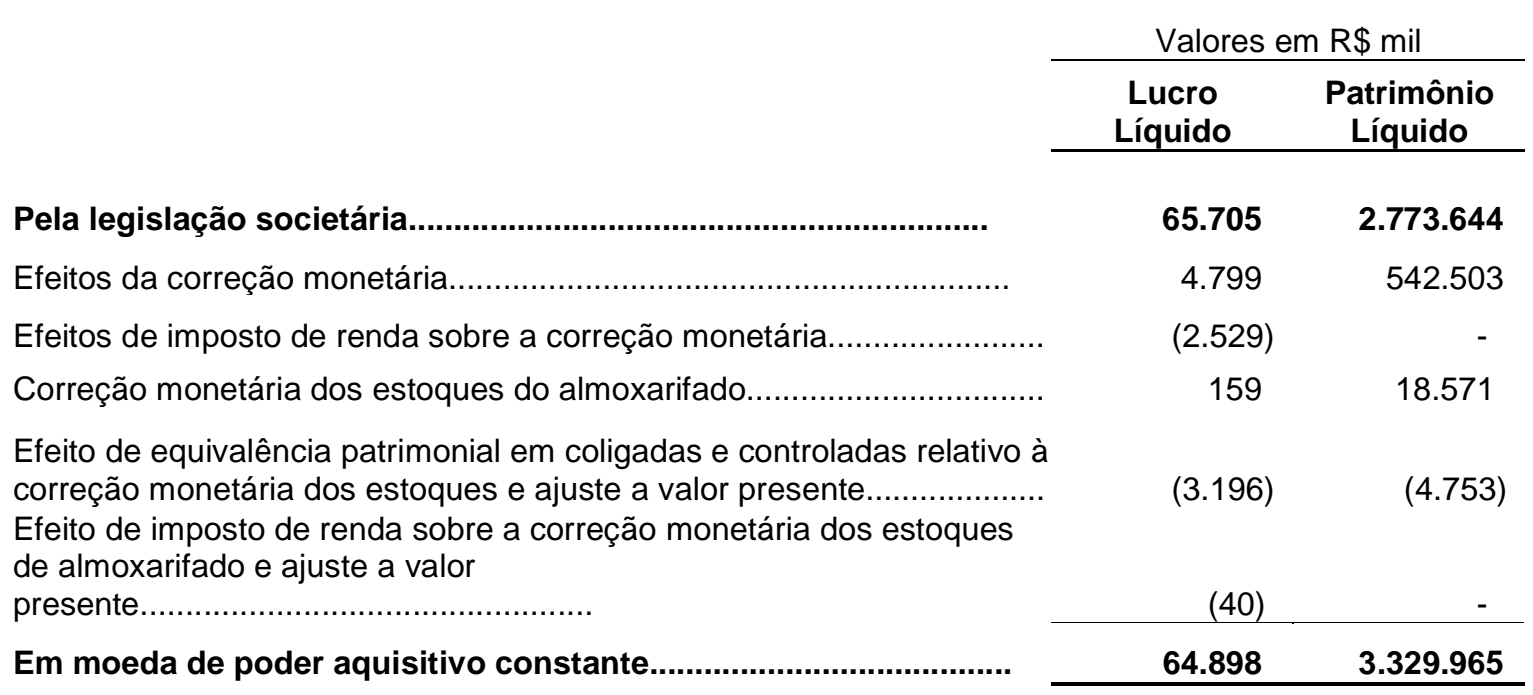

Fonte: Jornal A Tarde, 29.01.98 
Tabela 16 - COPENE - Petroquímica do Nordeste S.A. - Balanço Patrimonial em USGAAP Consolidado em 31 de Dezembro de 1997

\begin{tabular}{|c|c|c|c|c|c|}
\hline \multicolumn{2}{|c|}{ CONTAS } & \multirow{2}{*}{$\begin{array}{c}\text { Moeda } \\
\text { Constante } \\
\text { em } R \$ \text { mil }\end{array}$} & \multirow{2}{*}{$\begin{array}{c}\text { (A) } \\
\text { Moeda } \\
\text { Constante } \\
\text { em US\$ mil }\end{array}$} & \multirow{2}{*}{$\begin{array}{c}\text { (B) } \\
\text { US GAAP } \\
\text { publicado } \\
\text { em US\$ mil }\end{array}$} & \multirow[b]{2}{*}{$\begin{array}{c}\text { Variação \% } \\
(B / A-1)\end{array}$} \\
\hline $\begin{array}{c}\text { BRASIL } \\
\text { Moeda Constante }\end{array}$ & US GAAP & & & & \\
\hline ATIVO & ASSETS & & & & \\
\hline Caixa e Bancos + Aplicações financeiras & Cash and cash equivalents & 20.166 & 18.063 & 85.906 & $375,58 \%$ \\
\hline Títulos e valores mobiliários & Time deposits & 171.930 & 154.004 & 183.515 & $19,16 \%$ \\
\hline \multirow[t]{2}{*}{ Títulos a receber } & Notes receivable: Related parties + Other & 26.419 & 23.664 & 23.664 & $0,00 \%$ \\
\hline & Prepaid pension costs & - & - & 41.639 & \\
\hline Outras contas a receber & Other & 52.857 & 47.346 & 7.034 & $-85,14 \%$ \\
\hline \multirow[t]{2}{*}{ Realizável a Longo Prazo } & Other Assets & 223.834 & 200.496 & 282.782 & $41,04 \%$ \\
\hline & Time deposits & - & - & 39.111 & \\
\hline \multirow[t]{2}{*}{ Repasse de financiamentos } & Loans-related parties & 20.901 & 18.722 & 30.696 & $63,96 \%$ \\
\hline & Deferred income taxes & - & - & 26.705 & \\
\hline Outras contas a receber & Other & 17.602 & 15.767 & 3.007 & $-80,93 \%$ \\
\hline Investimentos & Investments & 169.815 & 152.109 & 179.971 & $18,32 \%$ \\
\hline Sociedades coligadas & Affiliated companies & 72.835 & 65.241 & 133.753 & $105,01 \%$ \\
\hline $\begin{array}{l}\text { Outros } \\
\text { Imobilizado }\end{array}$ & $\begin{array}{l}\text { Other } \\
\text { Property, Plant and Equipment, net }\end{array}$ & $\begin{array}{r}96.980 \\
3.375 .232\end{array}$ & $\begin{array}{r}86.869 \\
3.023 .318\end{array}$ & $\begin{array}{r}46.218 \\
1.737 .989\end{array}$ & $\begin{array}{l}-46,80 \% \\
-42,51 \%\end{array}$ \\
\hline Diferido & $\begin{array}{l}\text { Deferred Charges, Net } \\
\text { Investments on discontinued operations }\end{array}$ & $\begin{array}{r}304.071 \\
-\end{array}$ & $\begin{array}{c}272.367 \\
-\end{array}$ & $\begin{array}{l}51.332 \\
50.359\end{array}$ & $-81,15 \%$ \\
\hline Total do Ativo & Total Assets & 4.630 .531 & 4.147 .735 & 2.882 .569 & \\
\hline
\end{tabular}




\begin{tabular}{|c|c|c|c|c|c|}
\hline \multicolumn{2}{|c|}{ CONTAS } & \multirow[b]{2}{*}{$\begin{array}{c}\text { Moeda } \\
\text { Constante } \\
\text { em R } \$ \text { mil }\end{array}$} & \multirow{2}{*}{$\begin{array}{c}\text { (A) } \\
\text { Moeda } \\
\text { Constante } \\
\text { em US\$ mil } \\
\end{array}$} & \multirow{2}{*}{\begin{tabular}{|c|} 
(B) \\
US GAAP \\
publicado \\
em US\$ mil \\
\end{tabular}} & \multirow[b]{2}{*}{$\begin{array}{c}\text { Variação \% } \\
(B / A-1)\end{array}$} \\
\hline $\begin{array}{c}\text { BRASIL } \\
\text { Moeda Constante }\end{array}$ & US GAAP & & & & \\
\hline PASSIVO & LIABILITIES AND SHAREHOLDER'S EQUITY & & & & \\
\hline Circulante & Current Liabilities & 370.648 & 332.003 & 414.121 & $24,73 \%$ \\
\hline Fornecedores & Suppliers: Related parties + Other & 75.300 & 67.449 & 65.902 & $-2,29 \%$ \\
\hline Financiamentos + Títulos comerciais no exterior & $\begin{array}{l}\text { Current portion of long-term debt }+ \text { Short-term } \\
\text { financing }+ \text { Accrued finance charges }\end{array}$ & 227.982 & 204.212 & 327.971 & $60,60 \%$ \\
\hline Participações nos lucros e resultados & & 2.061 & 1.846 & - & \\
\hline Dividendos propostos a pagar & & 28.920 & 25.905 & - & \\
\hline Outras contas a pagar & Other & 12.053 & 10.796 & 9.432 & $-12,64 \%$ \\
\hline Exigível a Longo Prazo & Long-Term Liabilities & 865.809 & 775.537 & 800.231 & $3,18 \%$ \\
\hline Financiamentos + Títulos comerciais no exterior & Long-Term debts & 833.065 & 746.207 & 758.828 & $1,69 \%$ \\
\hline Participação de Terceiros & Minority Interests & 38.977 & 34.913 & 25.024 & $-28,32 \%$ \\
\hline Patrimônio Líquido & Shareholder's Equity & 3.329 .965 & 2.982.771 & 1.643 .193 & $-44,91 \%$ \\
\hline Total do Passivo & Total Liabilities and Shareholder's Equity & 4.630 .531 & 4.147.735 & 2.882 .569 & \\
\hline
\end{tabular}

Fonte: O Balanço em US GAAP está disponível no site: www.copene.com.br

Taxa de câmbio divulgada pelo Banco Central do Brasil para 31.12.1997: $\quad$ US\$1,00 = R\$ 1,1164 
Tabela 17 - COPENE - Petroquímica do Nordeste S.A.

Balanço Patrimonial Consolidado em 31 de Dezembro de 1998.

\begin{tabular}{|c|c|c|c|c|c|c|}
\hline CONTAS & $\begin{array}{c}\text { Legislação } \\
\text { Societária em } \\
\mathrm{R} \$ \text { mil }\end{array}$ & $\begin{array}{c}\text { (A) } \\
\text { Legislação } \\
\text { Societária } \\
\text { em US\$ mil }\end{array}$ & $\begin{array}{c}\text { Moeda } \\
\text { Constante } \\
\text { em } R \$ \text { mil }\end{array}$ & $\begin{array}{c}\text { (B) } \\
\text { Moeda } \\
\text { Constante } \\
\text { em US\$ mil }\end{array}$ & $\begin{array}{c}\text { Variação } \\
\text { absoluta } \\
\text { (B - A) em } \\
\text { US\$ mil }\end{array}$ & $\begin{array}{c}\text { Variação \% } \\
(B / A-1)\end{array}$ \\
\hline \multicolumn{7}{|l|}{ ATIVO } \\
\hline Circulante & 455.336 & 376.809 & 473.588 & 391.913 & 15.104 & $4,01 \%$ \\
\hline Realizável a Longo Prazo & 313.963 & 259.817 & 318.632 & 263.681 & 3.864 & $1,49 \%$ \\
\hline Investimentos & 107.425 & 88.899 & 133.095 & 110.142 & 21.243 & $23,90 \%$ \\
\hline Imobilizado & 2.030 .127 & 1.680 .012 & 2.395 .653 & 1.982 .500 & 302.488 & $18,01 \%$ \\
\hline Diferido & 248.661 & 205.777 & 270.108 & 223.525 & 17.748 & $8,62 \%$ \\
\hline Total do Permanente & 2.386 .213 & 1.974 .688 & 2.798 .856 & 2.316 .167 & 341.479 & $17,29 \%$ \\
\hline Total do Ativo & 3.155 .512 & 2.611 .314 & 3.591 .076 & 2.971 .761 & 360.447 & $13,80 \%$ \\
\hline \multicolumn{7}{|l|}{ PASSIVO } \\
\hline Circulante & 368.293 & 304.777 & 370.295 & 306.434 & 1.657 & $0,54 \%$ \\
\hline Exigível a Longo Prazo & 785.539 & 650.065 & 785.598 & 650.114 & 49 & $0,01 \%$ \\
\hline Resultado Exercícios Futuros & 20.486 & 16.953 & 27.542 & 22.792 & 5.839 & $34,44 \%$ \\
\hline Participação de Terceiros & 32.150 & 26.605 & 36.629 & 30.312 & 3.707 & $13,93 \%$ \\
\hline Patrimônio Líquido & 1.949 .044 & 1.612 .913 & 2.371 .012 & 1.962 .109 & 349.196 & $21,65 \%$ \\
\hline Total do Passivo & 3.155 .512 & 2.611 .314 & 3.591 .076 & 2.971 .761 & 360.447 & $13,80 \%$ \\
\hline
\end{tabular}

Fonte: Diário Oficial do Estado da Bahia, 29.01.99.

Taxa de câmbio divulgada pelo Banco Central do Brasil para 31.12.1998: US\$1,00 = R\$ 1,2084 
Tabela 18 - COPENE - Petroquímica do Nordeste S.A.

Demonstração do Resultado para o Exercício findo em 31 de Dezembro de 1998

\begin{tabular}{|c|c|c|c|c|c|c|}
\hline CONTAS & $\begin{array}{c}\text { Legislação } \\
\text { Societária em } \\
\mathrm{R} \$ \text { mil }\end{array}$ & $\begin{array}{c}\text { (A) } \\
\text { Legislação } \\
\text { Societária em } \\
\text { US\$ mil }\end{array}$ & $\begin{array}{c}\text { Moeda } \\
\text { Constante } \\
\text { em } R \$ \text { mil }\end{array}$ & $\begin{array}{c}\text { (B) } \\
\text { Moeda } \\
\text { Constante } \\
\text { em US\$ mil }\end{array}$ & $\begin{array}{l}\text { Variação } \\
\text { absoluta } \\
\text { (B - A) em } \\
\text { US\$ mil }\end{array}$ & $\begin{array}{c}\text { Variação \% } \\
(\mathbf{B} / \mathbf{A}-1)\end{array}$ \\
\hline Receita Operacional Líquida & 1.249 .046 & 1.033 .636 & 1.253 .989 & 1.037 .727 & 4.091 & $0,40 \%$ \\
\hline Lucro Bruto & 270.226 & 223.623 & 245.541 & 203.195 & $(20.428)$ & $-9,13 \%$ \\
\hline Lucro Operacional & 63.805 & 52.801 & 36.061 & 29.842 & $(22.959)$ & $-43,48 \%$ \\
\hline Receitas (Despesas) Não Operacionais & $(67.226)$ & $(55.632)$ & $(82.005)$ & $(67.862)$ & $(12.230)$ & $21,98 \%$ \\
\hline $\begin{array}{l}\text { Provisão para Imposto de Renda + } \\
\text { Participações (líquido) }\end{array}$ & $(1.092)$ & (904) & 5.735 & 4.746 & 5.650 & $-625,18 \%$ \\
\hline Lucro (Prejuízo) Líquido do Exercício & $(4.513)$ & $(3.735)$ & $(40.209)$ & $(33.275)$ & $(29.540)$ & $790,96 \%$ \\
\hline
\end{tabular}

Fonte: Diário Oficial do Estado da Bahia, 29.01.99.

Taxa de câmbio divulgada pelo Banco Central do Brasil para 31.12.1998: US\$1,00 = R \$1,2084 
Tabela 19 - Conciliação do Lucro Líquido e do Patrimônio Líquido em 1998

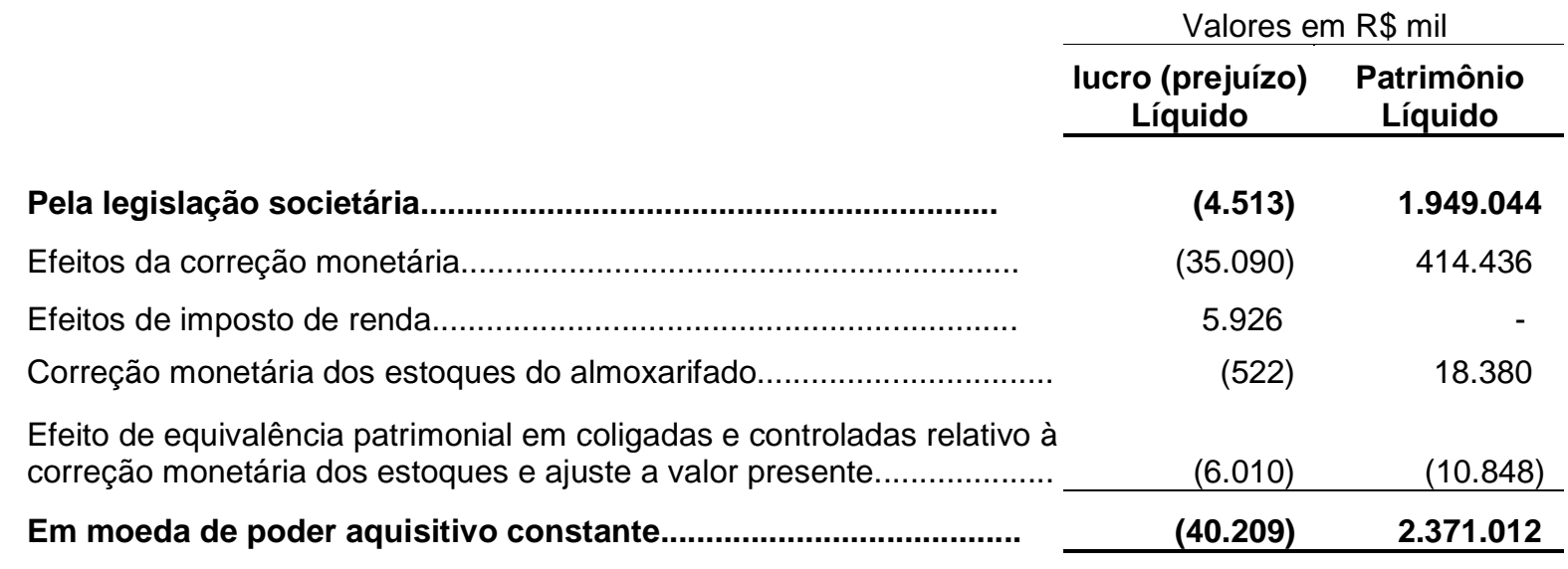

Fonte: Diário Oficial do Estado da Bahia, 29.01.99. 
Tabela 20 - COPENE - Petroquímica do Nordeste S.A. - Balanço Patrimonial em USGAAP Consolidado em 31 de Dezembro de 1998

\begin{tabular}{|c|c|c|c|c|c|}
\hline \multicolumn{2}{|c|}{ CONTAS } & \multirow{2}{*}{$\begin{array}{c}\text { Legislação } \\
\text { Societária em } \\
\mathbf{R} \$ \text { mil }\end{array}$} & \multirow{2}{*}{\begin{tabular}{|c|}
$(A)$ \\
Legislação \\
$\begin{array}{c}\text { Societária em } \\
\text { US\$ mil }\end{array}$
\end{tabular}} & \multirow{2}{*}{$\begin{array}{c}\text { (B) } \\
\text { US GAAP } \\
\text { publicado } \\
\text { em US\$ mil }\end{array}$} & \multirow[b]{2}{*}{$\begin{array}{c}\text { Variação \% } \\
(B / A-1)\end{array}$} \\
\hline $\begin{array}{c}\text { BRASIL } \\
\text { Legislação Societária }\end{array}$ & US GAAP & & & & \\
\hline ATIVO & ASSETS & & & & \\
\hline Caixa e Bancos + Aplicações financeiras & Cash and cash equivalents & 11.284 & 9.338 & 42.033 & $350,13 \%$ \\
\hline Títulos e valores mobiliários & Time deposits & 181.736 & 150.394 & 164.531 & $9,40 \%$ \\
\hline Títulos a receber & Notes receivable: Related parties + Other & 23.548 & 19.487 & 19.482 & $-0,03 \%$ \\
\hline- & Prepaid pension costs & - & - & 38.743 & \\
\hline Outras contas a receber & Other & 44.285 & 36.648 & 6.189 & $-83,11 \%$ \\
\hline Realizável a Longo Prazo & Other Assets & 313.963 & 259.817 & 281.890 & $8,50 \%$ \\
\hline & Time deposits & & & 22.353 & \\
\hline Imposto de renda diferido & Deferred income taxes & 40.565 & 33.569 & 45.361 & $35,13 \%$ \\
\hline Outras & Other & 3.038 & 2.514 & 2.866 & $14,00 \%$ \\
\hline Investimentos a alienar & Investments on discontinued operations & 48.445 & 40.090 & 38.544 & $-3,86 \%$ \\
\hline Investimentos & Investments & 107.425 & 88.899 & 171.642 & $93,08 \%$ \\
\hline Sociedades coligadas & Affiliated companies & 24.864 & 20.576 & 128.969 & $526,79 \%$ \\
\hline Outros & Other & 82.561 & 68.323 & 42.673 & $-37,54 \%$ \\
\hline Imobilizado & Property, Plant and Equipment, net & 2.030.127 & 1.680 .012 & 1.615 .667 & $-3,83 \%$ \\
\hline Diferido & Deferred Charges, Net & 248.661 & 205.777 & 40.996 & \\
\hline Total do Ativo & Total Assets & 3.155 .512 & 2.611.314 & 2.584 .532 & $-1,03 \%$ \\
\hline
\end{tabular}




\begin{tabular}{|c|c|c|c|c|c|}
\hline \multicolumn{2}{|c|}{ CONTAS } & \multirow[b]{2}{*}{$\begin{array}{c}\text { Legislação } \\
\text { Societária em } \\
\mathbf{R} \mathbf{~ m i l}\end{array}$} & \multirow{2}{*}{\begin{tabular}{|c|}
$(A)$ \\
Legislação \\
Societária em \\
US\$ mil
\end{tabular}} & \multirow{2}{*}{\begin{tabular}{|c|} 
(B) \\
US GAAP \\
publicado \\
em US\$ mil \\
\end{tabular}} & \multirow[b]{2}{*}{$\begin{array}{c}\text { Variação \% } \\
(B / A-1)\end{array}$} \\
\hline $\begin{array}{c}\text { BRASIL } \\
\text { Legislação Societária }\end{array}$ & US GAAP & & & & \\
\hline PASSIVO & LIABILITIES AND SHAREHOLDER'S EQUITY & & - & & \\
\hline Circulante & Current Liabilities & 368.293 & 304.777 & 333.418 & $9,40 \%$ \\
\hline Fornecedores & Suppliers: Related parties + Other & 44.359 & 36.709 & 35.789 & $-2,51 \%$ \\
\hline Financiamentos + Títulos comerciais no exterior & $\begin{array}{l}\text { Current portion of long-term debt }+ \text { Short-term } \\
\text { financing }+ \text { Accrued finance charges }\end{array}$ & 275.558 & 228.035 & 274.646 & $20,44 \%$ \\
\hline Participações nos lucros e resultados & & 2.238 & 1.852 & - & \\
\hline Dividendos propostos a pagar & & 18.311 & 15.153 & - & \\
\hline Outras contas a pagar & Other & 11.074 & 9.164 & 10.684 & $16,58 \%$ \\
\hline Exigível a Longo Prazo & Long-Term Liabilities & 785.539 & 650.065 & 672.082 & $3,39 \%$ \\
\hline Financiamentos + Títulos comerciais no exterior & Long-Term debts & 749.480 & 620.225 & 635.623 & $2,48 \%$ \\
\hline Participação de Terceiros & Minority Interests & 32.150 & 26.605 & 23.707 & $-10,89 \%$ \\
\hline Patrimônio Líquido & Shareholder's Equity & 1.949.044 & 1.612 .913 & 1.555 .325 & $-3,57 \%$ \\
\hline Total do Passivo & Total Liabilities and Shareholder's Equity & 3.155 .512 & 2.611.314 & 2.584 .532 & \\
\hline
\end{tabular}

Fonte: O Balanço em US GAAP está disponível no site: www.copene.com.br

Taxa de câmbio divulgada pelo Banco Central do Brasil para 31.12.1997: $\quad$ US\$1,00 = $\mathbf{R} \$ \mathbf{1 , 2 0 8 4}$ 
Tabela 21 - COPENE - Petroquímica do Nordeste S.A.

Balanço Patrimonial Consolidado em 31 de Dezembro de 1999.

\begin{tabular}{|c|c|c|c|c|c|c|}
\hline CONTAS & $\begin{array}{c}\text { Legislação } \\
\text { Societária em } \\
\mathrm{R} \$ \text { mil }\end{array}$ & $\begin{array}{c}\text { (A) } \\
\text { Legislação } \\
\text { Societária } \\
\text { em US\$ mil }\end{array}$ & $\begin{array}{c}\text { Moeda } \\
\text { Constante } \\
\text { em } R \$ \text { mil }\end{array}$ & $\begin{array}{c}\text { (B) } \\
\text { Moeda } \\
\text { Constante } \\
\text { em US\$ mil }\end{array}$ & $\begin{array}{c}\text { Variação } \\
\text { absoluta } \\
\text { (B - A) em } \\
\text { US\$ mil }\end{array}$ & $\begin{array}{c}\text { Variação \% } \\
(B / A-1)\end{array}$ \\
\hline \multicolumn{7}{|l|}{ ATIVO } \\
\hline Circulante & 960.034 & 536.632 & 987.153 & 551.790 & 15.159 & $2,82 \%$ \\
\hline Realizável a Longo Prazo & 309.674 & 173.099 & 309.674 & 173.099 & - & $0,00 \%$ \\
\hline Investimentos & 104.700 & 58.524 & 146.325 & 81.792 & 23.267 & $39,76 \%$ \\
\hline Imobilizado & 1.977 .171 & 1.105 .182 & 2.779 .823 & 1.553 .842 & 448.660 & $40,60 \%$ \\
\hline Diferido & 192.689 & 107.708 & 229.304 & 128.174 & 20.467 & $19,00 \%$ \\
\hline Total do Permanente & 2.584 .234 & 1.444 .513 & 3.465 .126 & 1.936 .907 & 492.394 & $34,09 \%$ \\
\hline Total do Ativo & 3.544 .268 & 1.981 .145 & 4.452 .279 & 2.488 .697 & 507.552 & $25,62 \%$ \\
\hline \multicolumn{7}{|l|}{ PASSIVO } \\
\hline Circulante & 434.678 & 242.973 & 434.678 & 242.973 & - & $0,00 \%$ \\
\hline Exigível a Longo Prazo & 972.861 & 543.802 & 973.063 & 543.914 & 113 & $0,02 \%$ \\
\hline Resultado Exercícios Futuros & 21.306 & 11.909 & 30.445 & 17.018 & 5.108 & $42,89 \%$ \\
\hline Participação de Terceiros & 30.147 & 16.851 & 40.778 & 22.794 & 5.942 & $35,26 \%$ \\
\hline Patrimônio Líquido & 2.085 .276 & 1.165 .610 & 2.973 .315 & 1.661 .998 & 496.388 & $42,59 \%$ \\
\hline Total do Passivo & 3.544 .268 & 1.981 .145 & 4.452 .279 & 2.488 .697 & 507.552 & $25,62 \%$ \\
\hline
\end{tabular}

Fonte: Diário Oficial do Estado da Bahia, 28.01.2000.

Taxa de câmbio divulgada pelo Banco Central do Brasil para 31.12.1999:US\$1,00 $=\quad \mathbf{R} \$ \mathbf{1 , 7 8 9 0}$ 
Tabela 22 - COPENE - Petroquímica do Nordeste S.A.

Demonstração do Resultado para o Exercício findo em 31 de Dezembro de 1999

\begin{tabular}{|c|c|c|c|c|c|c|}
\hline CONTAS & $\begin{array}{c}\text { Legislação } \\
\text { Societária em } \\
\mathrm{R} \$ \text { mil }\end{array}$ & $\begin{array}{c}\text { (A) } \\
\text { Legislação } \\
\text { Societária em } \\
\text { US\$ mil }\end{array}$ & $\begin{array}{c}\text { Moeda } \\
\text { Constante } \\
\text { em } R \$ \text { mil }\end{array}$ & $\begin{array}{c}\text { (B) } \\
\text { Moeda } \\
\text { Constante } \\
\text { em US\$ mil }\end{array}$ & $\begin{array}{l}\text { Variação } \\
\text { absoluta } \\
\text { (B - A) em } \\
\text { US\$ mil }\end{array}$ & $\begin{array}{c}\text { Variação \% } \\
(B / A-1)\end{array}$ \\
\hline Receita Operacional Líquida & 1.874 .761 & 1.047 .938 & 2.047 .422 & 1.144 .451 & 96.513 & $9,21 \%$ \\
\hline Lucro Bruto & 530.617 & 296.600 & 524.644 & 293.261 & (3.339) & $-1,13 \%$ \\
\hline Lucro Operacional & 236.292 & 132.080 & 237.622 & 132.824 & 743 & $0,56 \%$ \\
\hline Receitas (Despesas) Não Operacionais & (9.048) & (5.058) & (19.312) & (10.795) & $(5.737)$ & $113,44 \%$ \\
\hline $\begin{array}{l}\text { Provisão para Imposto de Renda + Participações } \\
\text { (líquido) }\end{array}$ & $(61.368)$ & $(34.303)$ & $(63.951)$ & $(35.747)$ & $(1.444)$ & $4,21 \%$ \\
\hline Lucro (Prejuízo) Líquido do Exercício & 165.876 & 92.720 & 154.359 & 86.282 & $(6.438)$ & $-6,94 \%$ \\
\hline
\end{tabular}

Fonte: Diário Oficial do Estado da Bahia, 28.01.2000.

Taxa de câmbio divulgada pelo Banco Central do Brasil para 31.12.1999:US\$1,00= R \$1,7890 
Tabela 23 - Conciliação do Lucro Líquido e do Patrimônio Líquido em 1999

\begin{tabular}{|c|c|c|}
\hline & \multicolumn{2}{|c|}{ Valores em $\mathrm{R} \$$ mil } \\
\hline & $\begin{array}{l}\text { lucro (prejuízo) } \\
\text { Líquido }\end{array}$ & $\begin{array}{l}\text { Patrimônio } \\
\text { Líquido }\end{array}$ \\
\hline 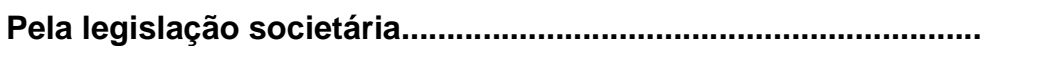 & 165.876 & 2.085 .276 \\
\hline Efeitos da correção monetária...... & 14.920 & 899.393 \\
\hline 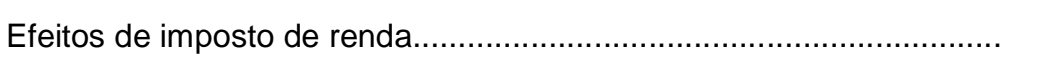 & (6.036) & - \\
\hline 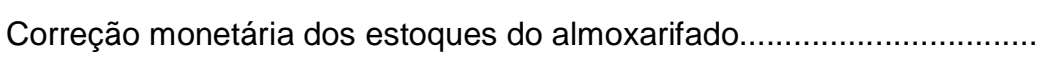 & 5.313 & 27.388 \\
\hline $\begin{array}{l}\text { Efeito de equivalência patrimonial em coligadas e controladas relativo à } \\
\text { correção monetária dos estoques e ajuste a valor presente.......................... }\end{array}$ & $(25.714)$ & $(38.742)$ \\
\hline 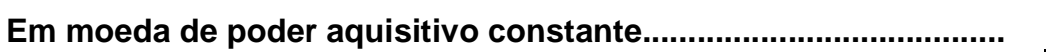 & 154.359 & 2.973.315 \\
\hline
\end{tabular}

Fonte: Diário Oficial do Estado da Bahia, 28.01.2000. 
Tabela 24 - COPENE - Petroquímica do Nordeste S.A. - Balanço Patrimonial em USGAAP Consolidado em 31 de Dezembro de 1999

\begin{tabular}{|c|c|c|c|c|c|}
\hline \multicolumn{2}{|c|}{ CONTAS } & \multirow{2}{*}{$\begin{array}{c}\text { Legislação } \\
\text { Societária em } \\
\text { R\$ mil }\end{array}$} & \multirow{2}{*}{$\begin{array}{c}\text { (A) } \\
\text { Legislação } \\
\begin{array}{c}\text { Societária em } \\
\text { US\$ mil }\end{array} \\
\end{array}$} & \multirow{2}{*}{$\begin{array}{c}\text { (B) } \\
\text { US GAAP } \\
\text { publicado } \\
\text { em US\$ mil } \\
\end{array}$} & \multirow[b]{2}{*}{$\begin{array}{c}\text { Variação \% } \\
(B / A-1)\end{array}$} \\
\hline $\begin{array}{c}\text { BRASIL } \\
\text { Legislação Societária }\end{array}$ & US GAAP & & & & \\
\hline ATIVO & ASSETS & & & & \\
\hline Circulante & Current Assets & 960.034 & 536.632 & 520.136 & $-3,07 \%$ \\
\hline $\begin{array}{l}\text { Caixa e Bancos + Aplicações financeiras + } \\
\text { Títulos e valores mobiliários }\end{array}$ & Cash and cash equivalents + Time deposits & 561.359 & 313.784 & 295.755 & $-5,75 \%$ \\
\hline Títulos a receber & Notes receivable: Related parties + Other & 30.503 & 17.050 & 17.050 & $0,00 \%$ \\
\hline- & Prepaid pension costs & - & - & 27.266 & \\
\hline Impostos retidos na fonte & & 40.545 & 22.663 & - & \\
\hline Outras contas a receber & Other & 19.095 & 10.674 & 7.652 & $-28,31 \%$ \\
\hline Realizável a Longo Prazo & Other Assets & 309.674 & 173.099 & 271.100 & $56,62 \%$ \\
\hline Sociedades controladas, coligadas e interligadas & s Loans-related parties & 36.376 & 20.333 & 22.887 & $12,56 \%$ \\
\hline Imposto de renda diferido & Deferred income taxes & 45.365 & 25.358 & 31.274 & $23,33 \%$ \\
\hline Outras & $\begin{array}{l}\text { Other } \\
\text { Investments on discontinued operations }\end{array}$ & 9.445 & $\begin{array}{r}5.279 \\
-\end{array}$ & $\begin{array}{r}2.471 \\
-\end{array}$ & $-53,20 \%$ \\
\hline Investimentos & Investments & 104.700 & 58.524 & 114.620 & $95,85 \%$ \\
\hline Sociedades coligadas & companies & 24.085 & 13.463 & 87.936 & $553,18 \%$ \\
\hline Outros & Other & 80.615 & 45.061 & 26.684 & $-40,78 \%$ \\
\hline $\begin{array}{l}\text { Imobilizado } \\
\text { Diferido }\end{array}$ & $\begin{array}{l}\text { Property, Plant and Equipment, net } \\
\text { Deferred Charges, Net }\end{array}$ & $\begin{array}{r}1.977 .171 \\
192.689 \\
\end{array}$ & $\begin{array}{r}1.105 .182 \\
107.708 \\
\end{array}$ & $\begin{array}{r}1.072 .753 \\
19.634 \\
\end{array}$ & $-2,93 \%$ \\
\hline Total do Ativo & Total Assets & 3.544 .268 & 1.981 .145 & 1.998 .243 & $0,86 \%$ \\
\hline
\end{tabular}




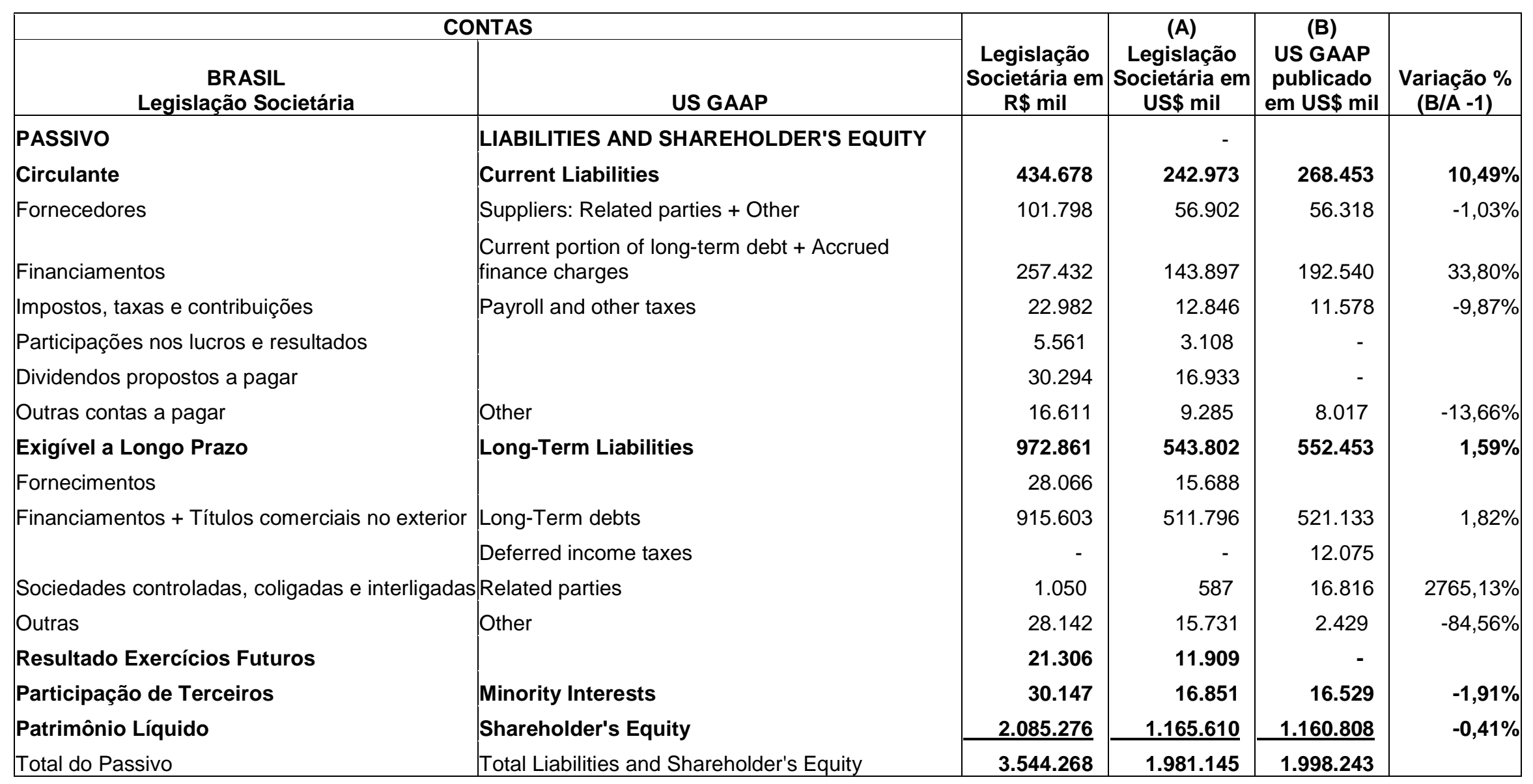

Fonte: O Balanço em US GAAP está disponível no site: www.copene.com.br

Taxa de câmbio divulgada pelo Banco Central do Brasil para 31.12.1997: $\quad$ US $\$ 1,00=\mathbf{R} \$ \mathbf{1 , 7 8 9 0}$ 



\subsection{Companhia Paranaense de Energia - COPEL}

Foram traduzidas para dólares e comparadas as demonstrações em moeda constante com as demonstrações elaboradas de acordo com a legislação societária brasileira, nos exercícios de 1997, 1998 e 1999.

Vale registrar que a empresa não apresentou nos EUA demonstrações contábeis de acordo com os US GAAP e sim a tradução das demonstrações publicadas no Brasil em moeda constante, para o exercício de 1997, e pela legislação societária, nos exercícios de 1998 e 1999, apresentando ainda a reconciliação do patrimônio líquido e do lucro líquido em US GAAP, para os três exercícios, a fim de evidenciar as diferenças de práticas contábeis nos dois países.

O balanço de 1996, publicado nos EUA, não estava disponível no site da empresa na internet no período da pesquisa, o mesmo foi solicitado à empresa, sem que esta tenha atendido à solicitação. Por esta razão, não foram analisadas as demonstrações desse ano.

Nas tabelas a seguir encontram-se os valores traduzidos para dólares do balanço patrimonial e da demonstração de resultado de 1997, 1998 e 1999, na qual verificam-se diferenças em valores absolutos e relativos encontradas na comparação das demonstrações publicadas no Brasil pela legislação societária e em moeda constante.

Destacam-se a seguir alguns dos itens que apresentaram variações nos três exercícios: 
- Consumidores e revendedores - o ajuste a valor presente feito pela correção integral nas contas a receber gerou uma redução no saldo dessa conta de 0,75\% em 1997 e 0,49\% em 1999, não tendo havido variação no ano de 1998;

- Serviços em curso - teve um acréscimo de 16,15\% apenas em 1998, relativo à correção monetária do período;

- Almoxarifado - apresentou os acréscimos de 1,32\% em 1997 e de $5,56 \%$ em 1999, relativos à correção dos materiais em estoque, sem variação em 1998;

- Investimentos - a correção monetária deste subgrupo provocou acréscimos de 14,16\% em 1997, 1,53\% em 1998 e 18,89\% em 1999;

- Imobilizado - este subgrupo foi aumentado em 16,09\% em 1997, $13,43 \%$ em 1998 e $29,23 \%$ em 1999;

- Taxas regulamentares - este item apresentou redução de 6,68\% em 1997 e 0,50\% em 1999, sem variação em 1998, referente ao ajuste a valor presente feito nas contas a pagar pela correção integral;

- Outras contas a pagar - também em função de ajuste a valor presente, este item apresentou redução em 1997 de 0,92\% no passivo circulante e de 6,89\% no exigível a longo prazo, e em 1999 teve redução de $7,73 \%$ no circulante e de $6,28 \%$ no exigível a longo prazo, sem variação em 1998; 
- Imposto de renda diferido - a expressiva variação apresentada neste item, nos três exercícios, refere-se ao imposto de renda incidente sobre os ajustes relativos aos efeitos inflacionários do período.

As tabelas 31 e 32 apresentam as reconciliações do patrimônio líquido e do lucro líquido, respectivamente, divulgadas nos EUA (nota explicativa nº 34), onde são apresentadas as diferenças entre as práticas contábeis adotadas pela empresa no Brasil e aquelas requeridas pelos US GAAP.

Dentre os itens mencionados nas referidas tabelas estão os juros capitalizados que, de acordo com os US GAAP, devem ser somados aos bens individuais a que se referirem e amortizados durante suas vidas úteis.

Outro item que apresenta diferença entre as práticas contábeis dos dois países é a contabilização das obrigações relativas a planos de pensão patrocinados pela empresa, conforme já abordado no capítulo 2. De acordo com as tabelas 31 e 32, a COPEL efetuou ajustes com vistas à adaptação aos critérios do SFAS $n^{0} 87$ (Contabilizações para pensões pelos empregados).

Por fim, destaque-se os dividendos propostos, os quais, de acordo com as normas brasileiras, são reconhecidos no período de competência, antes da aprovação pela assembléia geral de acionistas, enquanto que, pelas normas norte-americanas, os dividendos não são aprovisionados até que sejam formalmente declarados. 

Tabela 25 - Companhia Paranaense de Energia - COPEL

Balanço Patrimonial Consolidado em 31 de Dezembro de 1997

\begin{tabular}{|c|c|c|c|c|c|c|}
\hline CONTAS & \multirow[b]{2}{*}{$\begin{array}{l}\text { Legislação } \\
\text { Societária } \\
\text { em } \mathrm{R} \$ \text { mil }\end{array}$} & \multirow{2}{*}{\begin{tabular}{|c|}
$(\mathrm{A})$ \\
Legislação \\
Societária em \\
US\$ mil
\end{tabular}} & \multirow[b]{2}{*}{$\begin{array}{c}\text { Moeda } \\
\text { Constante } \\
\text { em } \mathrm{R} \$ \text { mil }\end{array}$} & \multirow{2}{*}{$\begin{array}{c}\text { (B) } \\
\text { Moeda } \\
\text { Constante } \\
\text { em US\$ mil }\end{array}$} & \multirow{2}{*}{$\begin{array}{c}\text { Variação } \\
\text { absoluta } \\
\text { (B - A) } \\
\text { em US\$ mil }\end{array}$} & \multirow[b]{2}{*}{$\begin{array}{c}\text { Variação } \\
\%(B / A-1)\end{array}$} \\
\hline ATIVO & & & & & & \\
\hline Consumidores e revendedores & 203.034 & 181.865 & 201.509 & 180.499 & $(1.366)$ & $-0,75 \%$ \\
\hline Provisão p/créd.liqu.duvidosa & $(4.427)$ & (3.965) & $(4.427)$ & (3.965) & - & $0,00 \%$ \\
\hline Repasse CRC governo Paraná & 7.059 & 6.323 & 7.059 & 6.323 & - & $0,00 \%$ \\
\hline Serviços em Curso & 30.350 & 27.186 & 30.350 & 27.186 & - & $0,00 \%$ \\
\hline Almoxarifado & 5.449 & 4.881 & 5.521 & 4.945 & 64 & $1,32 \%$ \\
\hline Antecipação de ICMS & 156.691 & 140.354 & 156.691 & 140.354 & - & $0,00 \%$ \\
\hline \multirow[t]{2}{*}{ Pagamentos antecipados e outros } & 48.894 & 43.796 & 47.510 & 42.556 & $(1.240)$ & $-2,83 \%$ \\
\hline & \multicolumn{6}{|c|}{ Realizável a Longo Prazo } \\
\hline Imposto de renda diferido & 47.225 & 42.301 & 47.225 & 42.301 & - & $0,00 \%$ \\
\hline Depósitos judiciais e outros & 116.628 & 104.468 & 116.628 & 104.468 & - & $0,00 \%$ \\
\hline \multirow[t]{2}{*}{ Contas a receber + Outros ativos realizáveis a longo prazo } & 33.143 & 29.687 & 33.143 & 29.687 & - & $0,00 \%$ \\
\hline & 704.312 & 630.878 & 704.312 & 630.878 & - & $0,00 \%$ \\
\hline \multicolumn{7}{|l|}{ Permanente } \\
\hline Investimentos & 82.534 & 73.929 & 94.223 & 84.399 & 10.470 & $14,16 \%$ \\
\hline \multirow[t]{2}{*}{ Imobilizado } & 5.532 .168 & 4.955.364 & 6.422 .128 & 5.752 .533 & 797.169 & $16,09 \%$ \\
\hline & 5.614 .702 & 5.029 .292 & 6.516 .351 & 5.836 .932 & 807.640 & $16,06 \%$ \\
\hline Total do Ativo & 7.436 .183 & 6.660 .859 & 8.334 .995 & 7.465 .958 & 805.099 & $12,09 \%$ \\
\hline
\end{tabular}

Fonte: Gazeta Mercantil, 20.02.98. 


\begin{tabular}{|c|c|c|c|c|c|c|}
\hline CONTAS & \multirow[b]{2}{*}{$\begin{array}{c}\text { Legislação } \\
\text { Societária em } \\
\mathrm{R} \$ \text { mil }\end{array}$} & \multirow{2}{*}{$\begin{array}{c}\text { (A) } \\
\text { Legislação } \\
\text { Societária } \\
\text { em US\$ mil }\end{array}$} & \multirow[b]{2}{*}{$\begin{array}{c}\text { Moeda } \\
\text { Constante } \\
\text { em } R \$ \text { mil }\end{array}$} & \multirow{2}{*}{$\begin{array}{c}\text { (B) } \\
\text { Moeda } \\
\text { Constante } \\
\text { em US\$ mil }\end{array}$} & \multirow{2}{*}{$\begin{array}{c}\text { Variação } \\
\text { absoluta } \\
\text { (B - A) } \\
\text { em US\$ mil }\end{array}$} & \multirow[b]{2}{*}{$\begin{array}{c}\text { Variação \% } \\
(B / A-1)\end{array}$} \\
\hline PASSIVO & & & & & & \\
\hline \begin{tabular}{|l|} 
Circulante \\
Fornecedores
\end{tabular} & 48.988 & 43.880 & 48.988 & 43.880 & - & $0,00 \%$ \\
\hline Empréstimos Financiamentos+Encargos dívida & 375.723 & 336.549 & 375.723 & 336.549 & - & $0,00 \%$ \\
\hline Folha de Pagamento e provisões trabalhistas & 70.367 & 63.030 & 70.367 & 63.030 & - & $0,00 \%$ \\
\hline Tributos e contribuições sociais & 61.397 & 54.996 & 61.397 & 54.996 & - & $0,00 \%$ \\
\hline Juros sobre o capital próprio & 70.592 & 63.232 & 70.592 & 63.232 & - & $0,00 \%$ \\
\hline Consumidores-pré-venda energia & 13.273 & 11.889 & 13.273 & 11.889 & - & $0,00 \%$ \\
\hline Taxas regulamentares(RGR/CCC) & 15.029 & 13.462 & 14.025 & 12.563 & (899) & $-6,68 \%$ \\
\hline Entidade de previdência privada & 11.833 & 10.599 & 11.833 & 10.599 & - & $0,00 \%$ \\
\hline Outras contas a pagar & 21.141 & 18.937 & 20.947 & 18.763 & $(174)$ & $-0,92 \%$ \\
\hline Exigi & 688.343 & 616.574 & 687.145 & 615.501 & (1.073) & $-0,17 \%$ \\
\hline Empréstimos e Financiamentos & 744.114 & 666.530 & 744.114 & 666.530 & - & $0,00 \%$ \\
\hline Entidade de previdência privada & 28.186 & 25.247 & 28.186 & 25.247 & - & $0,00 \%$ \\
\hline Consumidores-pré-venda energia & 43.535 & 38.996 & 43.535 & 38.996 & - & $0,00 \%$ \\
\hline Tributos e contribuições sociais & 158.991 & 142.414 & 158.991 & 142.414 & - & $0,00 \%$ \\
\hline Imposto de renda diferido & 200.936 & 179.986 & 462.117 & 413.935 & 233.949 & $129,98 \%$ \\
\hline Outras contas a pagar & 71.037 & 63.630 & 66.143 & 59.247 & $(4.384)$ & $-6,89 \%$ \\
\hline Obrigações especiais & 640.597 & 573.806 & 747.274 & 669.360 & 95.554 & $16,65 \%$ \\
\hline & 1.887 .396 & 1.690 .609 & 2.250 .360 & 2.015 .729 & 325.120 & $19,23 \%$ \\
\hline Capital Social & 1.169 .126 & 1.047.229 & 1.283 .507 & 1.149 .684 & 102.455 & $9,78 \%$ \\
\hline Reservas de Capital & 2.531 .877 & 2.267.894 & 2.985 .307 & 2.674 .048 & 406.154 & $17,91 \%$ \\
\hline Reservas de Lucros & 1.146 .663 & 1.027 .108 & 1.114.105 & 997.944 & $(29.163)$ & $-2,84 \%$ \\
\hline Recursos destinados aumento capital & 12.778 & 11.446 & 14.571 & 13.052 & 1.606 & $14,03 \%$ \\
\hline Total do Passivo & $\frac{4.860 .444}{7.436 .183}$ & $\frac{4.353 .676}{6.660 .859}$ & $\frac{5.397 .490}{8.334 .995}$ & $\frac{4.834 .728}{7.465 .958}$ & $\frac{481.052}{805.099}$ & $\begin{array}{l}11,05 \% \\
12,09 \%\end{array}$ \\
\hline
\end{tabular}


Tabela 26 - Companhia Paranaense de Energia - COPEL

Demonstração do Resultado para o Exercício findo em 31 de Dezembro de 1997

\begin{tabular}{|c|c|c|c|c|c|c|}
\hline CONTAS & $\begin{array}{c}\text { Legislação } \\
\text { Societária em } \\
\mathrm{R} \$ \text { mil } \\
\end{array}$ & \begin{tabular}{|c} 
(A) \\
Legislação \\
$\begin{array}{c}\text { Societária em } \\
\text { US\$ mil }\end{array}$ \\
\end{tabular} & $\begin{array}{l}\text { Moeda } \\
\text { Constante } \\
\text { em } R \$ \text { mil }\end{array}$ & $\begin{array}{c}\text { (B) } \\
\text { Moeda } \\
\text { Constante } \\
\text { em US\$ mil } \\
\end{array}$ & $\begin{array}{c}\text { Variação } \\
\text { absoluta } \\
\text { (B - A) } \\
\text { em US\$ mil }\end{array}$ & $\begin{array}{c}\text { Variação \% } \\
(\mathbf{B} / \mathbf{A}-1)\end{array}$ \\
\hline Receita operacional & 1.718 .093 & 1.538 .958 & 1.739 .275 & 1.557 .932 & 18.973 & $1,23 \%$ \\
\hline ICMS + PASEP + COFINS & $(421.186)$ & $(377.272)$ & $(429.072)$ & $(384.335)$ & (7.064) & $1,87 \%$ \\
\hline $\begin{array}{l}\text { Despesas Operacionais + Quota para conta de } \\
\text { consumo de combustível + Quota para a reserva } \\
\text { global de reversão }\end{array}$ & $(967.940)$ & $(867.019)$ & $(1.015 .095)$ & $(909.257)$ & $(42.238)$ & $4,87 \%$ \\
\hline Lucro Operacional & 328.967 & 294.668 & 295.108 & 264.339 & $(30.329)$ & $-10,29 \%$ \\
\hline $\begin{array}{l}\text { Receitas financeiras - Despesas financeiras - Juros } \\
\text { sobre o capital próprio }\end{array}$ & $(56.460)$ & $(50.573)$ & 133.619 & 119.687 & 170.261 & $-336,66 \%$ \\
\hline Resultado não-operacional & $(22.916)$ & $(20.527)$ & $(24.205)$ & $(21.681)$ & $(1.155)$ & $5,62 \%$ \\
\hline Lucro antes da Contr.Social e Imposto de Renda & 249.591 & 223.568 & 404.522 & 362.345 & 138.777 & $62,07 \%$ \\
\hline Contribuição Social + Imposto de Renda & $(72.523)$ & $(64.961)$ & $(73.334)$ & $(65.688)$ & $(726)$ & $1,12 \%$ \\
\hline Lucro antes das participações & 177.068 & 158.606 & 331.188 & 296.657 & 138.051 & $87,04 \%$ \\
\hline Participação nos resultados & $(24.500)$ & (21.946) & $(24.500)$ & $(21.946)$ & - & $0,00 \%$ \\
\hline Reversão dos juros sobre capital próprio & 150.000 & 134.360 & & & $(134.360)$ & \\
\hline Lucro Líquido do Exercício & 302.568 & 271.021 & 306.688 & 274.712 & 3.690 & $1,36 \%$ \\
\hline
\end{tabular}

Fonte: Gazeta Mercantil, 20.02.98.

Taxa de câmbio divulgada pelo Banco Central do Brasil para 31.12.1997: $\quad$ US $\$ 1,00=\mathbf{R} \$ \quad \mathbf{1 , 1 1 6 4}$ 
Tabela 27 - Companhia Paranaense de Energia - COPEL

Balanço Patrimonial Consolidado em 31 de Dezembro de 1998

\begin{tabular}{|c|c|c|c|c|c|c|}
\hline CONTAS & \multirow[b]{2}{*}{\begin{tabular}{|c|} 
Legislação \\
Societária em \\
$\mathrm{R} \$$ mil \\
\end{tabular}} & \multirow{2}{*}{\begin{tabular}{|c|}
$(\mathrm{A})$ \\
Legislação \\
$\begin{array}{c}\text { Societária em US\$ } \\
\text { mil }\end{array}$ \\
\end{tabular}} & \multirow[b]{2}{*}{$\begin{array}{c}\text { Moeda } \\
\text { Constante } \\
\text { em } R \$ \text { mil }\end{array}$} & \multirow{2}{*}{\begin{tabular}{|c|} 
(B) \\
Moeda \\
Constante \\
em US\$ mil \\
\end{tabular}} & \multirow{2}{*}{\begin{tabular}{|c|} 
Variação \\
absoluta \\
(B - A) \\
em US\$ mil \\
\end{tabular}} & \multirow[b]{2}{*}{\begin{tabular}{|c|} 
Variação \\
$\%(B / A-1$ \\
$1)$ \\
\end{tabular}} \\
\hline ATIVO & & & & & & \\
\hline Numerário disponível + Aplicações Financeiras & 212.628 & 175.958 & 212.628 & 175.958 & - & $0,00 \%$ \\
\hline Consumidores e revendedores & 221.303 & 183.137 & 221.303 & 183.137 & - & $0,00 \%$ \\
\hline Provisão p/créd.liqu.duvidosa & $(11.671)$ & $(9.658)$ & $(11.671)$ & (9.658) & - & $0,00 \%$ \\
\hline Serviços em Curso & 15.458 & 12.792 & 17.954 & 14.858 & 2.066 & $16,15 \%$ \\
\hline Almoxarifado & 10.449 & 8.647 & 10.449 & 8.647 & - & $0,00 \%$ \\
\hline Antecipação de ICMS & 123.007 & 101.793 & 123.007 & 101.793 & - & $0,00 \%$ \\
\hline \multirow{2}{*}{ Outros créditos a receber + Pagamentos antecipados } & 50.607 & 41.879 & 48.111 & 39.814 & $(2.066)$ & $-4,93 \%$ \\
\hline & \multicolumn{6}{|c|}{ Realizável a Longo Prazo } \\
\hline \multirow{2}{*}{ Outros créditos a receber } & 60.438 & 50.015 & 55.275 & 45.742 & $(4.273)$ & $-8,54 \%$ \\
\hline & 813.623 & 673.306 & 813.623 & 673.306 & & $0,00 \%$ \\
\hline Investimentos & 260.983 & 215.974 & 264.977 & 219.279 & 3.305 & $1,53 \%$ \\
\hline \multirow[t]{2}{*}{ Imobilizado } & 5.368 .669 & 4.442.791 & 6.089 .598 & 5.039 .389 & 596.598 & $13,43 \%$ \\
\hline & 5.629 .652 & 4.658.765 & 6.354 .575 & 5.258 .668 & 599.903 & $12,88 \%$ \\
\hline Total do Ativo & 7.072 .775 & 5.853 .008 & 7.797.698 & 6.452 .911 & 599.903 & $10,25 \%$ \\
\hline
\end{tabular}

Taxa de câmbio divulgada pelo Banco Central do Brasil para 31.12.1998: $\quad$ US\$1,00 = $\mathbf{R} \quad \mathbf{1 , 2 0 8 4}$

Fonte: Gazeta Mercantil, 16.03.99. 


\begin{tabular}{|c|c|c|c|c|c|c|}
\hline CONTAS & \multirow[b]{2}{*}{$\begin{array}{c}\text { Legislação } \\
\text { Societária em } \\
\mathrm{R} \$ \text { mil }\end{array}$} & \multirow{2}{*}{\begin{tabular}{|c|} 
(A) \\
$\begin{array}{c}\text { Legislação Societária } \\
\text { em US\$ mil }\end{array}$
\end{tabular}} & \multirow[b]{2}{*}{$\begin{array}{c}\text { Moeda } \\
\text { Constante } \\
\text { em } R \$ \text { mil }\end{array}$} & \multirow{2}{*}{\begin{tabular}{|c|} 
(B) \\
Moeda \\
Constante \\
em US\$ mil
\end{tabular}} & \multirow{2}{*}{$\begin{array}{c}\text { Variação } \\
\text { absoluta } \\
(B-A) \\
\text { em US\$ mil } \\
\end{array}$} & \multirow[b]{2}{*}{$\begin{array}{c}\text { Variação \% } \\
(B / A-1)\end{array}$} \\
\hline PASSIVO & & & & & & \\
\hline \multicolumn{7}{|l|}{ Circulante } \\
\hline Fornecedores & 53.724 & 44.459 & 53.724 & 44.459 & - & $0,00 \%$ \\
\hline Empréstimos Financiamentos+Encargos dívida & 173.139 & 143.280 & 173.139 & 143.280 & - & $0,00 \%$ \\
\hline Folha de Pagamento e provisões trabalhistas & 55.813 & 46.188 & 55.813 & 46.188 & - & $0,00 \%$ \\
\hline Tributos e contribuições sociais & 68.509 & 56.694 & 68.509 & 56.694 & - & $0,00 \%$ \\
\hline Juros sobre o capital próprio & 122.422 & 101.309 & 122.422 & 101.309 & - & $0,00 \%$ \\
\hline Consumidores-pré-venda energia & 12.364 & 10.232 & 12.364 & 10.232 & - & $0,00 \%$ \\
\hline Taxas regulamentares(RGR/CCC) & 23.513 & 19.458 & 23.513 & 19.458 & - & $0,00 \%$ \\
\hline Entidade de previdência privada & 26.906 & 22.266 & 26.906 & 22.266 & - & $0,00 \%$ \\
\hline \multirow{2}{*}{ Outras contas a pagar } & 25.921 & 21.451 & 25.921 & 21.451 & - & $0,00 \%$ \\
\hline & \multicolumn{6}{|c|}{ Exigível a Longo Prazo } \\
\hline Empréstimos e Financiamentos & 917.140 & 758.971 & 917.140 & 758.971 & - & $0,00 \%$ \\
\hline Entidade de previdência privada & 456.613 & 377.866 & 456.613 & 377.866 & - & $0,00 \%$ \\
\hline Consumidores-pré-venda energia & 35.108 & 29.053 & 35.108 & 29.053 & - & $0,00 \%$ \\
\hline Tributos e contribuições sociais & 55.826 & 46.198 & 55.826 & 46.198 & - & $0,00 \%$ \\
\hline Imposto de renda diferido & - & - & 213.439 & 176.629 & 176.629 & \\
\hline Outras contas a pagar & 78.136 & 64.661 & 78.136 & 64.661 & - & $0,00 \%$ \\
\hline \multirow{2}{*}{ Obrigações especiais } & 508.720 & 420.986 & 586.732 & 485.545 & 64.558 & $15,33 \%$ \\
\hline & \multicolumn{5}{|c|}{ Patrimônio Líquido } & $14,21 \%$ \\
\hline Capital Social & 1.225 .351 & 1.014 .028 & 1.339 .732 & 1.108 .683 & 94.655 & $9,33 \%$ \\
\hline Reservas de Capital & 1.927 .099 & 1.594 .753 & 2.261 .944 & 1.871 .850 & 277.098 & $17,38 \%$ \\
\hline Reservas de Lucros & 1.293 .693 & 1.070 .583 & 1.276 .146 & 1.056 .063 & (14.521) & $-1,36 \%$ \\
\hline \multirow[t]{3}{*}{ Recursos destinados aumento capital } & 12.778 & 10.574 & 14.571 & 12.058 & 1.484 & $14,03 \%$ \\
\hline & 4.458 .921 & 3.689 .938 & 4.892 .393 & 4.048 .654 & 358.716 & $9,72 \%$ \\
\hline & 7.072 .775 & 5.853 .008 & 7.797 .698 & 6.452 .911 & 599.903 & $10,25 \%$ \\
\hline
\end{tabular}


Tabela 28 - Companhia Paranaense de Energia - COPEL

Demonstração do Resultado para o Exercício findo em 31 de Dezembro de 1998

\begin{tabular}{|c|c|c|c|c|c|c|}
\hline CONTAS & $\begin{array}{c}\text { Legislação } \\
\text { Societária em } \\
\mathrm{R} \$ \text { mil } \\
\end{array}$ & \begin{tabular}{|c|}
$(\mathrm{A})$ \\
Legislação \\
$\begin{array}{c}\text { Societária em } \\
\text { US\$ mil }\end{array}$ \\
\end{tabular} & $\begin{array}{l}\text { Moeda } \\
\text { Constante } \\
\text { em } R \$ \text { mil }\end{array}$ & $\begin{array}{c}\text { (B) } \\
\text { Moeda } \\
\text { Constante } \\
\text { em US\$ mil } \\
\end{array}$ & $\begin{array}{c}\text { Variação } \\
\text { absoluta } \\
(B-A) \\
\text { em US\$ mil } \\
\end{array}$ & $\begin{array}{l}\text { Variação \% } \\
(B / A-1)\end{array}$ \\
\hline Receita operacional & 1.862 .030 & 1.540 .905 & 1.862 .030 & 1.540 .905 & - & $0,00 \%$ \\
\hline ICMS + PASEP + COFINS & $(427.267)$ & (353.581) & $(427.267)$ & (353.581) & - & $0,00 \%$ \\
\hline $\begin{array}{l}\text { Despesas Operacionais + Quota para a reserva } \\
\text { global de reversão }\end{array}$ & $(1.058 .583)$ & $(876.020)$ & $(1.092 .321)$ & $(903.940)$ & $(27.920)$ & $3,19 \%$ \\
\hline Lucro Operacional & 376.180 & 311.304 & 342.442 & 283.385 & $(27.920)$ & $-8,97 \%$ \\
\hline Resultado da equivalência patrimonial & (8.631) & (7.143) & $(8.631)$ & (7.143) & - & $0,00 \%$ \\
\hline $\begin{array}{l}\text { Receitas financeiras - Despesas financeiras - Juros } \\
\text { sobre o capital próprio }\end{array}$ & $(39.889)$ & $(33.010)$ & 93.057 & 77.008 & 110.018 & $-333,29 \%$ \\
\hline Resultado não-operacional & 55.967 & 46.315 & 51.616 & $\mathbf{4 2 . 7 1 4}$ & (3.601) & $-7,77 \%$ \\
\hline Lucro antes da Contr.Social e Imposto de Renda & 383.627 & 317.467 & 478.484 & 395.965 & 78.498 & $24,73 \%$ \\
\hline Contribuição Social + Imposto de Renda & $(102.562)$ & $(84.874)$ & $(89.994)$ & $(74.474)$ & 10.401 & $-12,25 \%$ \\
\hline Lucro antes das participações & 281.065 & 232.593 & 388.490 & 321.491 & 88.899 & $38,22 \%$ \\
\hline Participação nos resultados & $(14.000)$ & (11.586) & $(14.000)$ & (11.586) & - & $0,00 \%$ \\
\hline Reversão dos juros sobre capital próprio & 136.200 & 112.711 & & & $(112.711)$ & \\
\hline Lucro Líquido do Exercício & 403.265 & 333.718 & 374.490 & 309.906 & $(23.812)$ & $-7,14 \%$ \\
\hline
\end{tabular}

Fonte: Gazeta Mercantil, 16.03.99.

Taxa de câmbio divulgada pelo Banco Central do Brasil para 31.12.1998: US\$1,00 = $\mathbf{R} \$ \mathbf{1 , 2 0 8 4}$ 
Tabela 29 - Companhia Paranaense de Energia - COPEL

Balanço Patrimonial Consolidado em 31 de Dezembro de 1999

\begin{tabular}{|c|c|c|c|c|c|c|}
\hline CONTAS & \multirow[b]{2}{*}{$\begin{array}{c}\text { Legislação } \\
\text { Societária em } \\
\mathrm{R} \$ \text { mil }\end{array}$} & \multirow{2}{*}{$\begin{array}{c}\text { (A) } \\
\text { Legislação } \\
\text { Societária } \\
\text { em US\$ mil }\end{array}$} & \multirow[b]{2}{*}{$\begin{array}{c}\text { Moeda } \\
\text { Constante } \\
\text { em R } \$ \text { mil }\end{array}$} & \multirow{2}{*}{$\begin{array}{c}\text { (B) } \\
\text { Moeda } \\
\text { Constante } \\
\text { em US\$ mil }\end{array}$} & \multirow{2}{*}{\begin{tabular}{|c|} 
Variação \\
absoluta \\
(B - A) \\
em US\$ mil
\end{tabular}} & \multirow[b]{2}{*}{$\begin{array}{c}\text { Variação \% } \\
(B / A-1)\end{array}$} \\
\hline ATIVO & & & & & & \\
\hline \multicolumn{7}{|l|}{ Circulante } \\
\hline Numerário disponível & 20.596 & 11.513 & 20.596 & 11.513 & - & $0,00 \%$ \\
\hline Aplicações Financeiras & 159.850 & 89.352 & 159.850 & 89.352 & - & $0,00 \%$ \\
\hline Consumidores e revendedores & 293.963 & 164.317 & 292.519 & 163.510 & $(807)$ & $-0,49 \%$ \\
\hline Provisão p/créd.liqu.duvidosa & $(6.796)$ & (3.799) & $(6.796)$ & (3.799) & - & $0,00 \%$ \\
\hline Repasse CRC governo Paraná & 10.335 & 5.777 & 10.335 & 5.777 & - & $0,00 \%$ \\
\hline Serviços em Curso & 14.298 & 7.992 & 14.298 & 7.992 & - & $0,00 \%$ \\
\hline Outros créditos a receber & 32.025 & 17.901 & 32.025 & 17.901 & - & $0,00 \%$ \\
\hline Almoxarifado & 12.294 & 6.872 & 12.977 & 7.254 & 382 & $5,56 \%$ \\
\hline Antecipação de ICMS & 182.392 & 101.952 & 182.392 & 101.952 & - & $0,00 \%$ \\
\hline Pagamentos antecipados & 5.056 & 2.826 & 5.056 & 2.826 & - & \\
\hline \multicolumn{7}{|l|}{ Realizável a Longo Prazo } \\
\hline Imposto de renda e contribuição social diferidos & 191.308 & 106.936 & 191.308 & 106.936 & - & $0,00 \%$ \\
\hline Depósitos judiciais & 64.109 & 35.835 & 64.109 & 35.835 & - & $0,00 \%$ \\
\hline Repasse CRC governo Paraná & 599.797 & 335.269 & 599.797 & 335.269 & - & $0,00 \%$ \\
\hline \multirow{2}{*}{ Outros créditos a receber } & 35.473 & 19.828 & 35.473 & 19.828 & & \\
\hline & \multicolumn{5}{|c|}{ Permanente } & $0,00 \%$ \\
\hline Investimentos & 328.171 & 183.438 & 390.171 & 218.094 & 34.656 & $18,89 \%$ \\
\hline \multirow[t]{2}{*}{ Imobilizado } & 5.758 .556 & 3.218 .869 & 7.475 .888 & 4.178.808 & 959.940 & $29,82 \%$ \\
\hline & 6.086 .727 & 3.402 .307 & 7.866 .059 & 4.396 .903 & 994.596 & $29,23 \%$ \\
\hline Total do Ativo & 7.701.427 & 4.304.878 & 9.479 .998 & 5.299 .049 & 994.170 & $23,09 \%$ \\
\hline
\end{tabular}




\begin{tabular}{|c|c|c|c|c|c|c|}
\hline CONTAS & & & & (B) & & \\
\hline PASSIVO & $\begin{array}{c}\text { Legislação } \\
\text { Societária em } \\
\mathrm{R} \$ \text { mil }\end{array}$ & $\begin{array}{l}\text { Legislação } \\
\text { Societária } \\
\text { em US\$ mil }\end{array}$ & $\begin{array}{c}\text { Moeda } \\
\text { Constante } \\
\text { em } R \$ \text { mil }\end{array}$ & $\begin{array}{c}\text { Moeda } \\
\text { Constante } \\
\text { em US\$ mil }\end{array}$ & $\begin{array}{c}\text { absoluta } \\
\text { (B - A) } \\
\text { em US\$ mil }\end{array}$ & $\begin{array}{c}\text { Variação \% } \\
(B / A-1)\end{array}$ \\
\hline Circulante & & & & & & \\
\hline Fornecedores & 86.099 & 48.127 & 86.099 & 48.127 & - & $0,00 \%$ \\
\hline Empréstimos e Financiamentos & 301.584 & 168.577 & 301.584 & 168.577 & - & $0,00 \%$ \\
\hline Folha de Pagamento e provisões trabalhistas & 51.182 & 28.609 & 51.182 & 28.609 & - & $0,00 \%$ \\
\hline Tributos e contribuições sociais & 81.891 & 45.775 & 81.891 & 45.775 & - & $0,00 \%$ \\
\hline Provisão p/imposto de renda contribuição social & 4.572 & 2.556 & 4.572 & 2.556 & - & $0,00 \%$ \\
\hline Juros sobre o capital próprio & 101.796 & 56.901 & 101.796 & 56.901 & - & $0,00 \%$ \\
\hline Consumidores-pré-venda energia & 13.079 & 7.311 & 13.079 & 7.311 & - & $0,00 \%$ \\
\hline Taxas regulamentares(RGR/CCC) & 20.122 & 11.248 & 20.022 & 11.192 & (56) & $-0,50 \%$ \\
\hline $\begin{array}{l}\text { Entidade de previdência privada } \\
\text { Outras contas a pagar }\end{array}$ & $\begin{array}{l}19.692 \\
24.738 \\
\end{array}$ & $\begin{array}{l}11.007 \\
13.828\end{array}$ & $\begin{array}{l}19.692 \\
22.826 \\
\end{array}$ & $\begin{array}{l}11.007 \\
12.759\end{array}$ & $\begin{array}{c}- \\
(1.069)\end{array}$ & $\begin{array}{r}0,00 \% \\
-7,73 \%\end{array}$ \\
\hline Exigível a Longo Prazo & 704.755 & 393.938 & 702.743 & 392.813 & & \\
\hline Empréstimos e Financiamentos & 1.117 .391 & 624.590 & 1.117 .391 & 624.590 & - & $0,00 \%$ \\
\hline Entidade de previdência privada & 478.156 & 267.276 & 478.156 & 267.276 & - & $0,00 \%$ \\
\hline Consumidores-pré-venda energia & 24.044 & 13.440 & 24.044 & 13.440 & - & $0,00 \%$ \\
\hline Tributos e contribuições sociais & 129.468 & 72.369 & 129.468 & 72.369 & - & \\
\hline Imposto de renda e contribuição social diferidos & - & - & 607.372 & 339.504 & 339.504 & \\
\hline Outras contas a pagar & 92.408 & 51.653 & 86.608 & 48.411 & (3.242) & $-6,28 \%$ \\
\hline Obrigações especiais & 527.654 & 294.944 & 527.654 & 294.944 & & $0,00 \%$ \\
\hline Patrimônio Líquido & 2.369 .121 & 1.324 .271 & 2.970 .693 & 1.660 .533 & 336.262 & \\
\hline Capital Social & 1.620 .247 & 90 & 276 & 010 & 38 & $35,92 \%$ \\
\hline Reservas de Capital & 1.546 .446 & 864.419 & 2.220 .374 & 1.241 .126 & 376.707 & $43,58 \%$ \\
\hline Reservas de Lucros & 1.460 .858 & 816.578 & 1.383 .912 & 773.567 & $(43.011)$ & $-5,27 \%$ \\
\hline & 4.627 .551 & 2.586 .669 & 5.806 .562 & 3.245 .703 & 659.034 & $25,48 \%$ \\
\hline Total do Passivo & 7.701 .427 & 4.304 .878 & 9.479 .998 & 5.299 .049 & 994.170 & $23,09 \%$ \\
\hline
\end{tabular}

Fonte: Diário Oficial do Estado do Paraná, 22.03.2000. 
Tabela 30 - Companhia Paranaense de Energia - COPEL

Demonstração do Resultado para o Exercício findo em 31 de Dezembro de 1999

\begin{tabular}{|c|c|c|c|c|c|c|}
\hline CONTAS & $\begin{array}{l}\text { Legislação } \\
\text { Societária em } \\
\mathrm{R} \$ \text { mil } \\
\end{array}$ & \begin{tabular}{|c|} 
(A) \\
Legislação \\
$\begin{array}{c}\text { Societária em } \\
\text { US\$ mil }\end{array}$ \\
\end{tabular} & $\begin{array}{l}\text { Moeda } \\
\text { Constante } \\
\text { em } R \$ \text { mil }\end{array}$ & $\begin{array}{c}\text { (B) } \\
\text { Moeda } \\
\text { Constante } \\
\text { em US\$ mil } \\
\end{array}$ & $\begin{array}{c}\text { Variação } \\
\text { absoluta } \\
(A-B) \\
\text { em US\$ mil } \\
\end{array}$ & $\begin{array}{c}\text { Variação \% } \\
(\text { A/B -1) }\end{array}$ \\
\hline Receita operacional & 2.204 .906 & 1.232 .480 & 2.335 .439 & 1.305 .444 & (72.964) & $-5,59 \%$ \\
\hline Imposto sobre circulação de mercadorias e serviços & $(466.068)$ & $(260.519)$ & $(512.228)$ & $(286.321)$ & 25.802 & $-9,01 \%$ \\
\hline Quota para a reserva global de reversão & $(47.712)$ & (26.670) & $(45.262)$ & (25.300) & (1.369) & $5,41 \%$ \\
\hline PASEP & $(14.111)$ & (7.888) & $(16.451)$ & $(9.196)$ & 1.308 & $-14,22 \%$ \\
\hline COFINS & $(65.129)$ & $(36.405)$ & $(70.251)$ & (39.268) & 2.863 & $-7,29$ \\
\hline Despesas Operacionais & $(1.219 .057)$ & $(681.418)$ & $(1.351 .897)$ & $(755.672)$ & 74.254 & $-9,83 \%$ \\
\hline Resultado do Serviço & 392.829 & 219.580 & 339.350 & 189.687 & 29.893 & $15,76 \%$ \\
\hline Resultado da equivalência patrimonial & 3.755 & 2.099 & 3.981 & 2.225 & $(126)$ & $-5,68 \%$ \\
\hline $\begin{array}{l}\text { Receitas financeiras } \\
\text { Despesas financeiras + Juros sobre o capital } \\
\text { próprio }\end{array}$ & $\begin{array}{r}263.497 \\
(374.038) \\
\end{array}$ & $\begin{array}{r}147.287 \\
(209.077) \\
\end{array}$ & $\begin{array}{l}145.079 \\
(66.399) \\
\end{array}$ & $\begin{array}{r}81.095 \\
(37.115) \\
\end{array}$ & $\begin{array}{r}66.192 \\
(171.961) \\
\end{array}$ & $\begin{array}{r}81,62 \% \\
463,32 \%\end{array}$ \\
\hline Lucro Operacional & 286.043 & 159.890 & 422.011 & 235.892 & (76.002) & $-32,22 \%$ \\
\hline Resultado não-operacional & $(20.257)$ & $(11.323)$ & $(22.834)$ & $(12.764)$ & 1.440 & $-11,29 \%$ \\
\hline Lucro antes da Contr.Social e Imposto de Renda & 265.786 & 148.567 & 399.177 & 223.129 & (74.562) & $-33,42 \%$ \\
\hline Contribuição Social + Imposto de Renda & (88.621) & (49.537) & $(100.559)$ & $(56.210)$ & 6.673 & $-11,87 \%$ \\
\hline Participação nos resultados & $(10.000)$ & $(5.590)$ & $(10.000)$ & (5.590) & - & $0,00 \%$ \\
\hline Reversão dos juros sobre capital próprio & 110.000 & 61.487 & & & 61.487 & \\
\hline Lucro Líquido do Exercício & 277.165 & 154.927 & 288.618 & 161.329 & $(6.402)$ & $-3,97 \%$ \\
\hline
\end{tabular}

Fonte: Diário Oficial do Estado do Paraná, 22.03.2000. 
Tabela 31 - Companhia Paranaense de Energia - COPEL

Reconciliação do Patrimônio Líquido em relação às diferenças entre as normas contábeis do Brasil e dos Estados Unidos.

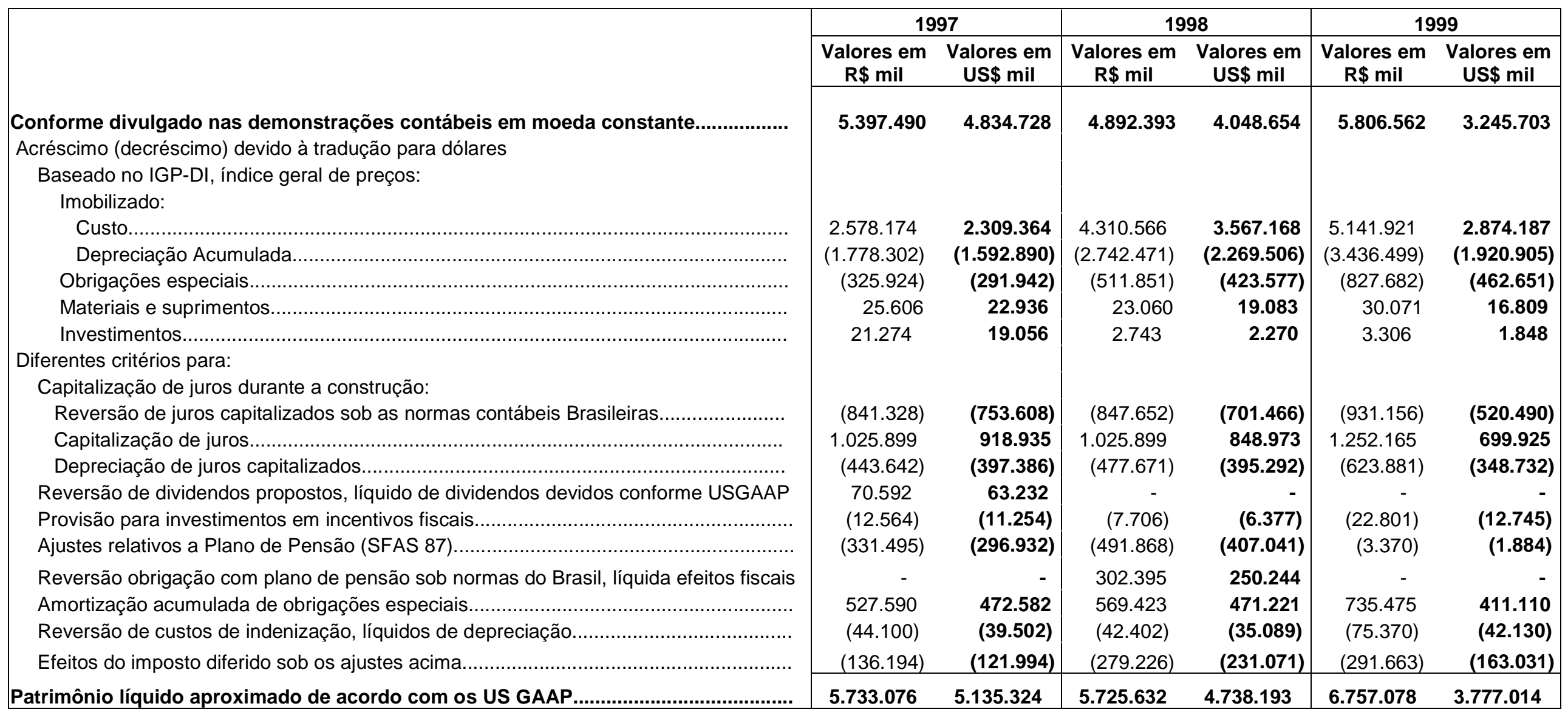

Fonte: Tradução livre do original em inglês diponível no site da COPEL na internet: www.copel.com.br

Taxa de câmbio divulgada pelo Banco Central do Brasil para 31.12.1997:

US $\$ 1,00=\mathbf{R} \$ \quad \mathbf{1 , 1 1 6 4}$

Taxa de câmbio divulgada pelo Banco Central do Brasil para 31.12.1998: $\quad$ US\$1,00 = $\mathbf{R} \quad \mathbf{1 , 2 0 8 4}$

Taxa de câmbio divulgada pelo Banco Central do Brasil para 31.12.1999: $\quad$ US\$1,00 = R\$ $\quad \mathbf{1 , 7 8 9 0}$ 
Tabela 32 - Companhia Paranaense de Energia - COPEL

Reconciliação do Lucro Líquido em relação às diferenças entre as normas contábeis do Brasil e dos Estados Unidos.

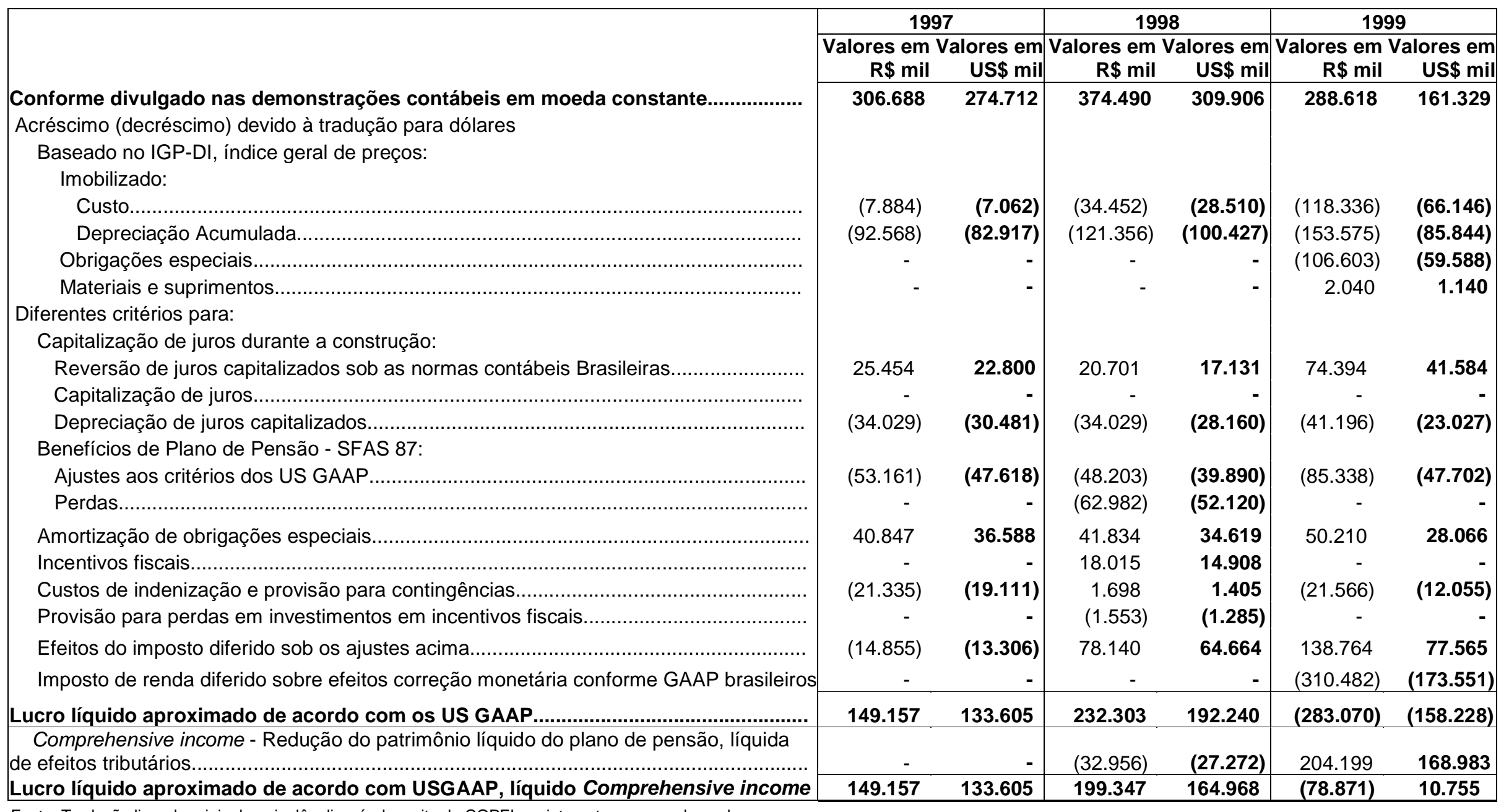

Fonte: Tradução livre do original em inglês diponível no site da COPEL na internet: $\underline{w w w . c o p e l . c o m . b r}$

Taxa de câmbio divulgada pelo Banco Central do Brasil para 31.12.1997: $\quad$ US $\$ 1,00=\mathbf{R} \$ \mathbf{1 , 1 1 6 4}$

Taxa de câmbio divulgada pelo Banco Central do Brasil para 31.12.1998: $\quad$ US\$1,00 = R \$ $\mathbf{1 , 2 0 8 4}$

Taxa de câmbio divulgada pelo Banco Central do Brasil para 31.12.1999: $\quad$ US $\$ 1,00=\mathbf{R} \$ \quad \mathbf{1 , 7 8 9 0}$ 


\subsection{Embratel Participações S.A.}

Foram traduzidas para dólares as demonstrações contábeis resumidas do exercício de 1999, publicadas de acordo com a legislação societária e em moeda de capacidade aquisitiva constante.

Não foi possível apresentar as variações dos períodos de 1996 e 1997, visto que a empresa não apresentou demonstrações em moeda constante nesses exercícios. Com relação às demonstrações em moeda constante de 1998, estas não estavam mais disponíveis no site da empresa na Internet.

A EMBRATEL não publicou nos EUA suas demonstrações financeiras de acordo com os US GAAP, optando por apresentar suas demonstrações contábeis de acordo com a legislação societária brasileira, a partir de 1998, inclusive para fins de apresentação à Comissão de Valores Mobiliários dos Estados Unidos (US SEC).

Nas demonstrações contábeis relativas aos períodos 2000, 1999 e 1998, divulgadas nos EUA, a empresa apresenta na nota explicativa no 2.c as demonstrações resumidas de acordo com o Método de Correção Integral (moeda constante), para os exercícios de 1998 e 1999, em moeda de 31.12.1999, assim como a reconciliação entre o lucro líquido e o patrimônio líquido apurados pela Legislação societária e pela Correção Integral. 
O balanço patrimonial e a demonstração do resultado de 1999 foram comparados nas tabelas 33 e 34 , respectivamente, a fim de evidenciar as variações ocorridas nos valores em moeda constante, em face da não consideração dos efeitos inflacionários nas demonstrações elaboradas de acordo com a legislação societária brasileira. O ano de 1998 não foi analisado pelo fato de não terem sido obtidas as demonstrações em moeda constante em moeda de 31.12.1998.

Não foi possível especificar as variações ocorridas dentro de cada subgrupo do ativo e do passivo e dos resultados apresentados na demonstração do resultado, em virtude de que as demonstrações em moeda constante foram divulgadas de forma resumida. Mesmo a reconciliação do lucro líquido e do patrimônio líquido não dá subsídios para análises mais detalhadas, visto que apresenta os efeitos da inflação em uma única linha denominada "Efeitos da inflação nas demonstrações contábeis (principalmente no ativo permanente)", conforme tabela 35 a seguir.

Na nota explicativa nº 27 às demonstrações contábeis relativas aos períodos 2000, 1999 e 1998, divulgadas nos EUA, são apresentadas as diferenças entre as práticas contábeis adotadas pela empresa e aquelas requeridas pelos US GAAP, assim como uma reconciliação entre o patrimônio líquido e o lucro líquido constantes das demonstrações elaboradas no Brasil e o que seriam o patrimônio líquido e o lucro líquido de acordo com os US GAAP.

Referida reconciliação é apresentada na tabela 36, onde são evidenciadas as diferenças entre as práticas contábeis dos dois países, 
algumas das quais são comentadas a seguir, com base nas informações prestadas pela empresa em notas explicativas:

- Correção monetária de 1996 e 1997 - até $1^{\circ}$ de julho de 1997 o Brasil ainda era considerado um país de economia altamente inflacionária pelos critérios dos US GAAP enquanto que, pela legislação societária brasileira, a correção monetária deixou de ser efetuada a partir do exercício de 1996, de modo que os valores de acordo com os US GAAP incluem até dois anos de inflação adicional, conforme já comentado no capítulo 1;

- Juros capitalizados - a empresa informou (nota explicativa 27.a) que, até 31 de dezembro de 1993, os juros capitalizados não eram somados aos itens individuais no ativo imobilizado e sim capitalizados separadamente e amortizados ao longo de um período de tempo diferente das vidas úteis dos bens correspondentes e, de acordo com os US GAAP, os juros capitalizados são somados aos bens individuais e amortizados durante suas vidas úteis;

- Dividendos propostos e juros sobre o capital - de acordo com as normas brasileiras os dividendos/juros sobre o capital são reconhecidos no período de competência, antes da aprovação pela assembléia geral de acionistas, ao passo que, nos EUA, não são aprovisionados até que sejam formalmente declarados, conforme já discutido no capítulo 2; 
- Pensões e outros benefícios pós-aposentadoria - conforme a nota explicativa 27.e, a companhia provisionou estes custos com base em um percentual fixo de remuneração, tendo sido feitos os ajustes mencionados na tabela 36 com vista à adaptação aos critérios do SFAS $n^{\circ} 87$ (Contabilizações para pensões pelos empregados) e do SFAS $\mathrm{n}^{\circ} 106$ (Contabilização dos benefícios pós-aposentadoria que não são pensões pelos empregados);

- Itens lançados diretamente nas contas do patrimônio líquido pelas normas contábeis brasileiras, vários itens são lançados no patrimônio líquido, os quais, de acordo com os US GAAP, devem ser lançados em contas de resultado, como é o caso dos efeitos dos ajustes às alíquotas de impostos e créditos recebidos de investimentos em incentivos fiscais. 

Tabela 33 - EMBRATEL Participações S.A. Controladas

Balanço Patrimonial Consolidado em 31 de Dezembro de 1999

\begin{tabular}{|c|c|c|c|c|c|c|}
\hline CONTAS & $\begin{array}{c}\text { Legislação } \\
\text { Societária em } \\
\mathrm{R} \$ \text { mil }\end{array}$ & $\begin{array}{c}\text { (A) } \\
\text { Legislação } \\
\text { Societária em } \\
\text { US\$ mil }\end{array}$ & \begin{tabular}{|c} 
Moeda \\
Constante em \\
$\mathrm{R} \$$ mil \\
\end{tabular} & \begin{tabular}{|c|} 
(B) \\
Moeda \\
$\begin{array}{c}\text { Constante em } \\
\text { US\$ mil }\end{array}$ \\
\end{tabular} & $\begin{array}{c}\text { Variação } \\
\text { absoluta } \\
\text { (B - A) } \\
\text { em US\$ mil }\end{array}$ & $\begin{array}{c}\text { Variação \% } \\
(B / A-1)\end{array}$ \\
\hline \multicolumn{7}{|l|}{ ATIVO } \\
\hline Circulante & 2.213 .880 & 1.237.496 & 2.213 .880 & 1.237.496 & - & $0,00 \%$ \\
\hline Realizável a Longo Prazo & 363.599 & 203.241 & 363.599 & 203.241 & - & $0,00 \%$ \\
\hline Permanente & 7.075 .988 & 3.955 .276 & 8.986 .861 & 5.023 .399 & 1.068 .124 & $27,01 \%$ \\
\hline Total do Ativo & 9.653 .467 & 5.396 .013 & 11.564 .340 & 6.464 .136 & 1.068 .124 & $19,79 \%$ \\
\hline \multicolumn{7}{|l|}{ PASSIVO } \\
\hline Circulante & 2.556 .537 & 1.429 .031 & 2.652 .353 & 1.482 .590 & 53.558 & $3,75 \%$ \\
\hline Exigível a Longo Prazo & 1.195 .564 & 668.286 & 1.860 .165 & 1.039 .779 & 371.493 & $55,59 \%$ \\
\hline Receitas Antecipadas & 110.721 & 61.890 & - & - & $(61.890)$ & \\
\hline Participações Minoritárias & 72.657 & 40.613 & 88.473 & 49.454 & 8.841 & \\
\hline Patrimônio Líquido & 5.717 .988 & 3.196 .192 & 6.963 .349 & 3.892 .314 & 696.121 & $21,78 \%$ \\
\hline Total do Passivo & 9.653 .467 & 5.396 .013 & 11.564 .340 & 6.464 .136 & 1.068 .124 & $19,79 \%$ \\
\hline
\end{tabular}

Fonte: disponível no site da Embratel (http://www.embratel.com.br)

Taxa de câmbio divulgada pelo Banco Central do Brasil para 31.12.1999: US $\$ 1,00=\mathbf{R} \$ \mathbf{1 , 7 8 9 0}$ 
Tabela 34 - EMBRATEL Participações S.A. Controladas

Demonstração do Resultado para o Exercício findo em 31 de Dezembro de 1999

\begin{tabular}{|c|c|c|c|c|c|c|}
\hline CONTAS & $\begin{array}{c}\text { Legislação } \\
\text { Societária em } \\
\mathrm{R} \$ \text { mil }\end{array}$ & $\begin{array}{c}\text { (A) } \\
\text { Legislação } \\
\text { Societária em } \\
\text { US\$ mil }\end{array}$ & $\begin{array}{c}\text { Moeda } \\
\text { Constante } \\
\text { em } R \$ \text { mil } \\
\end{array}$ & $\begin{array}{c}(B) \\
\text { Moeda } \\
\text { Constante } \\
\text { em US\$ mil } \\
\end{array}$ & $\begin{array}{c}\text { Variação } \\
\text { absoluta } \\
\text { (B - A) } \\
\text { em US\$ mil }\end{array}$ & $\begin{array}{c}\text { Variação \% } \\
(B / A-1)\end{array}$ \\
\hline Receita operacional líquida & 5.183 .927 & 2.897.667 & 5.527 .113 & 3.089 .499 & 191.831 & $6,62 \%$ \\
\hline Lucro bruto & 1.564 .013 & 874.239 & 1.471 .055 & 822.278 & $(51.961)$ & $-5,94 \%$ \\
\hline Lucro operacional & 491.771 & 274.886 & 480.097 & 268.361 & $(6.525)$ & $-2,37 \%$ \\
\hline $\begin{array}{l}\text { Lucro (prejuízo) líquido antes de } \\
\text { impostos e participações }\end{array}$ & 454.121 & 253.841 & 425.235 & 237.694 & $(16.146)$ & $-6,36 \%$ \\
\hline Lucro Líquido do Exercício & 411.631 & 230.090 & 398.213 & 222.590 & $(7.500)$ & $-3,26 \%$ \\
\hline
\end{tabular}

Fonte: disponível no site da Embratel (http://www.embratel.com.br)

Taxa de câmbio divulgada pelo Banco Central do Brasil para 31.12.1999: $\quad$ US\$1,00 $=\mathbf{R} \$ \mathbf{1}, 7890$ 
Tabela 35 - Conciliação do Lucro Líquido e do Patrimônio Líquido entre Legislação Societária e Correção Integral

1999

\begin{tabular}{cc}
\multicolumn{2}{c}{1999} \\
\hline $\begin{array}{c}\text { Vucro } \\
\text { Líquido }\end{array}$ & $\begin{array}{c}\text { Patrimônio } \\
\text { Líquido }\end{array}$ \\
\hline $\mathbf{4 1 1 . 1 3 1}$ & $\mathbf{5 . 7 1 7 . 9 8 8}$ \\
$(33.068)$ & 1.910 .873 \\
- & - \\
19.650 & $(665.512)$ \\
\hline $\mathbf{3 9 8 . 2 1 3}$ & $\mathbf{6 . 9 6 3 . 3 4 9}$ \\
\hline
\end{tabular}

Fonte: disponível no site da Embratel (http://www.embratel.com.br)

$\left.{ }^{*}\right)$ Outros referem-se, basicamente, a impostos de renda diferidos e efeitos minoritários nos ajustes 
Tabela 36 - EMBRATEL Participações S.A. Controladas

Reconciliação do Lucro Líquido e do Patrimônio Líquido de 1999 em relação às diferenças entre as normas contábeis do Brasil e dos Estados Unidos.

\begin{tabular}{lcc}
\hline & $\begin{array}{c}\text { Lucro } \\
\text { Líquido }\end{array}$ & $\begin{array}{c}\text { Patrimônio } \\
\text { Líquido }\end{array}$ \\
\hline $\begin{array}{l}\text { Lucro/patrimônio líquido conforme divulgado } \\
\text { Adicionar (deduzir) - critérios diferentes para: }\end{array}$ & $\mathbf{4 1 1 . 6 3 1}$ & $\mathbf{5 . 7 1 7 . 9 8 8}$ \\
$\quad$ Correção monetária de 1996 e 1997 & $(67.064)$ & 382.570 \\
$\quad$ Juros capitalizados: & 51.870 & $(862.909)$ \\
$\quad$ Amortização de juros capitalizados & 63.112 & 570.004 \\
Reversão dos dividendos propostos e juros líquidos sobre o capital (1) & - & 13.065 \\
Pensão e outros benefícios pós-aposentadoria: & & \\
$\quad$ Ajuste pela SFAS 87, incluindo liquidação e interrupção & 8.217 & $(133.247)$ \\
$\quad$ Ajuste pela SFAS 106, incluindo liquidação e interrupção & $(6.966)$ & $(67.294)$ \\
Compensação de ações & 2.962 & - \\
$\quad$ Itens lançados diretamente nas contas do patrimônio líquido: & \multicolumn{2}{c}{-} \\
$\quad$ Investimentos em incentivos fiscais/doações e subsídios & 312 & - \\
Efeitos dos impostos diferidos nos ajustes acima & $(38.356)$ & 162.837 \\
$\quad$ Outros & - & - \\
Efeitos das participações minoritárias nos ajustes acima & $(975)$ & 4.133 \\
\hline Lucro líquido / patrimônio líquido de acordo com os GAAP norte-americanos & $\mathbf{4 2 4 . 7 4 3}$ & $\mathbf{5 . 7 8 7 . 1 4 7}$ \\
\hline
\end{tabular}

Fonte: disponível no site da Embratel (http://www.embratel.com.br) 


\section{CONCLUSÕES}

A seguir serão apresentados os comentários finais e as conclusões obtidas ao longo deste trabalho.

Inicialmente foram comentados os principais métodos existentes para se efetuar a tradução de demonstrações contábeis para moeda estrangeira, os quais definem a taxa de câmbio a ser utilizada e os demais procedimentos da tradução, de acordo com a base conceitual de cada um. A principal distinção entre os métodos é a exigência de traduzir saldos de contas de ativos e passivos ou à taxa corrente ou à taxa histórica.

Neste trabalho foram analisados os métodos: temporal, monetário/não monetário, corrente/não corrente e o método da taxa corrente; assim como os pronunciamentos emitidos pelo FASB acerca da tradução de demonstrações contábeis para moeda estrangeira: o SFAS $n^{\circ} 8$ e o SFAS $n^{\circ}$ 52.

O SFAS $n^{0} 8$ utilizava o método temporal e o SFAS $n^{0} 52$, que substituiu o SFAS $n^{\circ} 8$, recomenda o uso do método da taxa corrente para empresas localizadas em economias estáveis e o método temporal no caso de economias altamente inflacionárias, consideradas como tal as economias cujo efeito cumulativo da inflação, em três anos consecutivos, se aproxima ou supera a marca de $100 \%$.

Conforme foi comentado no capítulo 3, a inflação tem estado presente por um longo tempo na história do Brasil. O convívio com a inflação por um período tão longo e com taxas tão exorbitantes, fez com que se 
desenvolvessem no Brasil estudos dos efeitos inflacionários e métodos de mensuração desses efeitos nas demonstrações contábeis das empresas, no sentido de salvaguardar a informação contábil da deterioração da moeda, que é a unidade de medida utilizada na Contabilidade.

A adoção no Brasil da técnica da Correção Monetária Integral das demonstrações contábeis fez com que surgissem formas alternativas de tradução das demonstrações contábeis para moeda estrangeira, cujas metodologias foram abordadas no capítulo 1.

Com o objetivo de eliminar a inflação, o governo implantou vários planos de estabilização econômica, culminando com o Plano Real, que em $1^{\circ}$ de julho de 1994 criou uma nova moeda, o Real, equivalente a 2.750 Cruzeiros Reais em 1994. Desde então, a moeda nacional passou a experimentar certa estabilidade, com a conseqüente queda nos índices de inflação.

Neste cenário de aparente estabilidade da economia, foi aprovada a Lei $n^{\circ} 9.249 / 95$, que em seu art. $4^{\circ}$, parágrafo único, vetou a utilização de qualquer sistema de correção monetária de demonstrações contábeis a partir de $1^{\circ}$ de janeiro de 1996.

Mesmo após essa data, a Correção Integral continuou sendo utilizada para fins de tradução das demonstrações contábeis de empresas brasileiras para moeda estrangeira, visto que nesse período o Brasil ainda era considerado um país de economia altamente inflacionária, do ponto de vista dos critérios norte-americanos e internacionais. 
A partir de $1^{\circ}$. de julho de 1997 o Brasil passou a ser considerado um país de economia com baixa inflação, pois apresentou um índice acumulado de inflação inferior a $100 \%$ nos últimos três anos, o que permitiu o uso do Real como moeda funcional, pelos critérios do SFAS ํㅜㄴ.

Dessa forma, a partir do exercício de 1998, as empresas brasileiras passaram a não mais considerar os efeitos inflacionários em suas demonstrações contábeis traduzidas para o dólar norte-americano e em conformidade com as práticas contábeis dos EUA (US GAAP), enquanto que nos exercícios de 1996 e 1997 tais efeitos foram reconhecidos nas demonstrações em US GAAP e não reconhecidos nas demonstrações divulgadas no Brasil, de acordo com a legislação societária.

Em função dessa circunstância, a data em que os ativos e passivos não-monetários foram "congelados" nas demonstrações preparadas em conformidade com a legislação societária brasileira difere das demonstrações em US GAAP, uma vez que as primeiras consideraram os efeitos inflacionários somente até 31 de dezembro de 1995 e estas últimas incluíram dois anos a mais de inflação (1996 e 1997).

Neste trabalho foram analisadas as demonstrações contábeis publicadas de empresas brasileiras que negociavam suas ações na Bolsa de Valores de Nova lorque no período de 1996 a 1999 e, por esse motivo, publicavam também demonstrações contábeis de acordo com as normas norte-americanas (US GAAP).

Para efeito de análise, foram traduzidas para dólares as demonstrações contábeis publicadas pelas empresas, de acordo com a 
legislação societária brasileira e em moeda de capacidade aquisitiva constante, relativas ao período de 1996 a 1999 e, em seguida, foram comparados os dois conjuntos de demonstrações, a fim de levantar as diferenças pelo não reconhecimento dos efeitos da inflação nas demonstrações elaboradas de acordo com a legislação societária brasileira.

Foram também reconciliadas determinadas contas das demonstrações em dólares, obtidas a partir das traduções efetuadas, com as demonstrações publicadas nos EUA de acordo com os US GAAP, com o objetivo de evidenciar as diferenças entre as práticas contábeis brasileiras e norte-americanas, com base nas informações prestadas pelas empresas em notas explicativas.

Em todas as empresas analisadas é possível observar que ocorreram variações significativas, para mais ou para menos, tanto no patrimônio líquido quanto no lucro líquido apresentado pelas empresas, podendo-se inferir que o não reconhecimento dos efeitos da perda do poder aquisitivo da moeda pode distorcer os valores apresentados nas demonstrações contábeis.

É importante ressaltar, conforme já comentado no capítulo 1, que as demonstrações contábeis apresentadas nos EUA, de acordo com as normas norte-americanas (US GAAP), relativas aos exercícios de 1996 e 1997, foram elaboradas considerando os efeitos inflacionários, diferentemente das demonstrações publicadas no Brasil, de acordo com a legislação societária brasileira, que a partir de 1996 deixaram de considerar tais efeitos. 
Dessa forma, nos períodos de 1996 e 1997 os investidores norteamericanos tiveram acesso a demonstrações contábeis significativamente diferentes daquelas apresentadas aos investidores brasileiros nos mesmos períodos.

A partir de 1998, quando o Brasil deixou de ser considerado um país de economia altamente inflacionária, por ter apresentado um índice de inflação acumulado no triênio inferior a 100\%, as demonstrações contábeis em US GAAP também deixaram de considerar os efeitos da inflação.

Desde então, investidores dos dois países têm acesso ao mesmo tipo de informação, porém, diante dos dados apresentados, observa-se que o não reconhecimento da perda do poder aquisitivo da moeda distorce significativamente os números divulgados nas demonstrações contábeis.

É importante ainda ressaltar que, apesar dos baixos índices de inflação observados após o Plano Real, o efeito cumulativo da inflação pode ser assustador e o abandono da correção monetária das demonstrações contábeis vem tornando inócuos os números apresentados pela Contabilidade.

Por fim, registre-se o posicionamento do Conselho Federal de Contabilidade (CFC) e do Instituto Brasileiro de Auditores Independentes (Ibracon), que apoiaram a extinção da correção monetária, de acordo com seus pronunciamentos mencionados no capítulo 3 , onde é comentada a impropriedade dessas medidas, que revelam a falta de compromisso com a relevância das demonstrações contábeis publicadas pelas empresas. 


\section{BIBLIOGRAFIA}

AICPA SEC Regulations Committee Highlights - International Practices Task Force - Washington Office, December 2, 1997. Disponível: Site do AICPA. URL: http://www.aicpa.org. Consulta: 22/04/2002)

ANDREZO, Andrea Fernandes; LIMA, Iran Siqueira. Mercado Financeiro Aspectos Históricos e Conceituais. 2. ed. São Paulo: Pioneira Thomson Learning, 2002.

BAPTISTA, Cristina. Na Capital do Dinheiro. Revista Veja. ed. Abril. № 15, ano 34, p.110-111, 18.abr.2001.

BARBIERI, Geraldo. Lucro Inflacionário e Fluxo de Caixa. Boletim IOB Temática Contábil e Balanços. Bol. 45, 1995.

BARBIERI, Geraldo; SANTOS, Ariovaldo dos. Fim da Correção Monetária de Balanços e início da Taxa de Juros de Longo Prazo (TJLP) sobre o capital próprio - Alguns de seus principais efeitos. Boletim IOB - Temática Contábil e Balanços. Bol. 16, 1996.

BLOOMER, Carrie. International Accounting Standard Setting: A Vision for the Future - Report of the FASB, 2000. Disponível na Internet via: Site do Financial Accounting Standards Board. URL: http://www.rutgers.edu/accounting/raw/fasb/iasc/ Consulta : 27 set. 2001.

CASTRO NETO, José Luís de. Contribuição ao Estudo da Prática Harmonizada da Contabilidade na União Européia. São Paulo, 1998. Tese (Doutorado em Contabilidade e Controladoria) Departamento de Contabilidade e Atuaria da Faculdade de Economia, Administração e Contabilidade da Universidade de São Paulo. 
CAUDRON, Shari. Expanding Horizons in Global Accounting. Controller Magazine, Nova lorque, NY, v.3, u.2, p.20-24, fev.1997.

CHOI, Frederick D. S; MUELLER, Gehard G. International Accounting. Prentice Hall, $2^{\mathrm{a}}$ ed. 1992.

Conselho Regional de Contabilidade do Estado de São Paulo. Contabilidade no Contexto Internacional - 9. São Paulo: Atlas, 1997.

DELANEY, Patrick R. et. al. GAAP 2000. Interpretation and Aplication of Generally Accepted Accounting Principles. John Villey and Sons, Inc. 2000.

Financial Accounting Standards Board. Statement of Financial Accounting Standards $\mathbf{N}^{\circ} \mathbf{5 2}$ Foreign Currency Translation. Current Text - Accounting Standards as of june 1, 1995. Vol. I. John Villey and Sons, Inc.

Financial Accounting Standards Board. Statement of Financial Accounting Standards $\mathrm{N}^{\circ} 08$ - Accounting for the Translation for Foreign Currency Transactions and Foreign Currency Financial Statements. In: Conversão de Balanços em Moeda Estrangeira, 1998. São Paulo. JCA Treinamentos.

FIPECAFI - Fundação Instituto de Pesquisas Contábeis, Atuariais e Financeiras. Aprendendo Contabilidade em Moeda Constante. São Paulo: Atlas, 1994.

FRANCO, Hilário. A Contabilidade na Era da Globalização: temas discutidos no XV Congresso Mundial de Contadores em Paris, 26 a 29-101997. São Paulo: Atlas, 1999.

GRECCO, Marta Cristina Pelucio. Tradução das Demonstrações Contábeis para Moeda Estrangeira: Uma Análise da Mudança Metodológica após o Plano Real. São Paulo, 2001. Dissertação (Mestrado em Contabilidade e Controladoria) - Departamento de Contabilidade e Atuária da Faculdade de Economia, Administração e Contabilidade da Universidade de São Paulo. 
HENDRIKSEN, Eldon S. \& VAN BREDA; Michael F. Teoria da Contabilidade. 5.ed. São Paulo: Atlas, 1999.

IOB - Calendário Objetivo de Obrigações e Tabelas Práticas - Setembro/1998

IUDÍCIBUS, Sérgio de. MARTINS, Eliseu. GELBECK, Ernesto Rubens. Manual de Contabilidade das Sociedades por Ações. 5a ed. rev. e atual. São Paulo: Atlas, 2000.

IUDÍCIBUS, Sérgio de. Teoria da Contabilidade. 6.ed. São Paulo: Atlas, 2000.

IUDíCIBUS, Sérgio de; MARION, José Carlos. Dicionário de Termos de Contabilidade. São Paulo: Atlas: 2001.

JALORETTO, José Gilberto. Conversão de Demonstrações Financeiras em Moedas Estrangeiras para Cruzados (Uma Contribuição à Avaliação dos Métodos Existentes). São Paulo, 1989. Dissertação (Mestrado em Contabilidade e Controladoria) - Departamento de Contabilidade e Atuária da Faculdade de Economia, Administração e Contabilidade da Universidade de São Paulo.

Lei $n^{\circ}$ 9.249, de 26 de dezembro de 1995.

LEMES, Sirlei. Harmonização das Normas Contábeis Brasileiras com as Internacionais do IASC - Um Estudo Comparativo Aplicado. São Paulo, 2000. Tese (Doutorado em Contabilidade e Controladoria) Departamento de Contabilidade e Atuaria da Faculdade de Economia, Administração e Contabilidade da Universidade de São Paulo.

LISBOA, Nahor Plácido. Harmonização de Normas e Práticas Contábeis no Mercosul. São Paulo, 2000. Tese (Doutorado em Contabilidade e Controladoria) Departamento de Contabilidade e Atuaria da Faculdade de Economia, Administração e Contabilidade da Universidade de São Paulo. 
MARTINS, Eliseu. A posição do Conselho Federal de Contabilidade com relação à atualização monetária dos balanços: decepção! Boletim IOB Temática Contábil e Balanços. Bol. 15 e 16, 2002.

MARTINS, Eliseu. Análise Comparativa dos Métodos "FAS-8" e "FAZ-52" de Conversão de Demonstrações Contábeis em Moeda Estrangeira. Boletim IOB - Temática Contábil e Balanços. Bol. 35, 36 e 37, 1995.

MARTINS, Eliseu. Conversão de Demonstrações Contábeis em Moeda Estrangeira - Introdução e "FAS-8". Boletim IOB - Temática Contábil e Balanços. Bol. 24, 25 e 26, 1995.

MARTINS, Eliseu. Conversão de Demonstrações Contábeis em Moeda Estrangeira - 0 "FAS-52". Boletim IOB - Temática Contábil e Balanços. Bol. 30, 31 e 32, 1995.

MARTINS, Eliseu. O "Método Brasileiro" de Conversão de Demonstrações Contábeis em Moeda Estrangeira. Boletim IOB - Temática Contábil e Balanços. Bol. 42, 43 e 44, 1995.

MARTINS, Gilberto de Andrade. Manual para Elaboração de Monografias e Dissertações. 2ª Ed. São Paulo: Atlas, 2000.

MOTA, Rui. Os Grandes Modelos Contabilísticos. In: Jornal do Técnico de Contas e da Empresa n² 294, Portugal, p.41-42, fev.1990.

NATAL, Lairton. Tradução Monetária das Demonstrações Financeiras para Moeda Estrangeira. Dissertação de Mestrado. São Paulo: FEA-USP, 1988.

OLIVEIRA, Heraldo Gilberto de. A Extinção da Correção Monetária no Brasil - Principais Implicações Contábeis e Tributárias. São Paulo, 1997. Dissertação (Mestrado em Contabilidade e Controladoria) - Departamento de Contabilidade e Atuária da Faculdade de Economia, Administração e Contabilidade da Universidade de São Paulo. 
PEREZ JÚNIOR, José Hernandez. Conversão de Demonstrações Contábeis para Moeda Estrangeira. 4ª Ed. São Paulo: Atlas, 2001.

PIMENTEL, Joéde da Silva. Tratamento Contábil das Transações e Demonstrações em Moeda Estrangeira. São Paulo, 1981. Dissertação (Mestrado em Contabilidade e Controladoria) - Departamento de Contabilidade e Atuária da Faculdade de Economia, Administração e Contabilidade da Universidade de São Paulo.

PORTO, Patrícia Cavalheiro Corrêa. Alguns Efeitos da Falta de Reconhecimento da Inflação nos Demonstrativos Contábeis e seus Impactos Financeiros - Um caso prático. São Paulo, 1998. Dissertação (Mestrado em Contabilidade e Controladoria) - Departamento de Contabilidade e Atuária da Faculdade de Economia, Administração e Contabilidade da Universidade de São Paulo.

SANTOS, Ariovaldo dos. Aspectos da Conversão de Demonstrações Financeiras para Moeda Estrangeira. São Paulo, 1981. Dissertação (Mestrado em Contabilidade e Controladoria) - Departamento de Contabilidade e Atuária da Faculdade de Economia, Administração e Contabilidade da Universidade de São Paulo.

SANTOS, Ariovaldo dos. Alguns Efeitos da Utilização de Índices Inadequados na Correção dos Balanços de Empresas Estrangeiras no Brasil. São Paulo, 1993. Tese (Doutorado em Contabilidade e Controladoria) Departamento de Contabilidade e Atuaria da Faculdade de Economia, Administração e Contabilidade da Universidade de São Paulo.

SANTOS, Ariovaldo dos. Resultado do Exercício: As Empresas Localizadas em Países com Baixas Taxas de Inflação São ou Não Afetadas? V Congresso Internacional de Custos. Acapulco, Gro. México. Julho 1997. 
SANTOS, Ariovaldo dos. Pior que decepção! Dá para entender os resultados publicados pela empresas? Boletim IOB - Temática Contábil e Balanços. Bol. 19, 2002. 